\title{
ipen
}

AUTARQUIA ASSOCIADA À UNIVERSIDADE DE SÃO PAULO

\section{OXIDAÇÃO ELETROQUÍMICA DO METANOL EM ELETRÓLITO ALCALINO POR INTERMÉDIO DE ELETROCATALISADORES PtRuIn/C PREPARADOS PELO MÉTODO DE REDUÇÃO POR BOROHIDRETO DE SÓDIO}

\author{
MONIQUE CAROLINA LIMA SANTOS
}

Dissertação apresentada como parte dos requisitos para obtenção do Grau de Mestre em ciências na área de Tecnologia Nuclear - Materiais

Orientador: Prof ${ }^{0}$. Dro . Almir Oliveira Neto

São Paulo 
INSTITUTO DE PESQUISAS ENERGÉTICAS E NUCLEARES

Autarquia associada à Universidade de São Paulo

\title{
OXIDAÇÃO ELETROQUÍMICA DO METANOL EM ELETRÓLITO ALCALINO POR INTERMÉDIO DE ELETROCATALISADORES PtRuIn/C PREPARADOS PELO MÉTODO DE REDUÇÃO POR BOROHIDRETO DE SÓDIO
}

\section{MONIQUE CAROLINA LIMA SANTOS}

\author{
Dissertação apresentada como parte dos requisitos \\ para obtenção do Grau de Mestre em ciências na área \\ de Tecnologia Nuclear - Materiais \\ Orientador: Prof ${ }^{\circ}$. Dro . Almir Oliveira Neto
}

Versão Original

Versão Original disponível no IPEN

São Paulo 
Dedico esta dissertação...

\author{
A Deus, pela graça da vida \\ Aos meus pais, pelo incentivo \\ e compreensão de todos os meus sonhos \\ Ao meu orientador, por todos os \\ conhecimentos transmitidos durante \\ o caminho percorrido até a finalização deste trabalho \\ Aqueles aos quais me \\ ajudaram a realizar o sonho de concluir \\ este mestrado \\ Aos apaixonados pela ciência \\ E a todos os que dedicarão \\ um dia seu tempo à ler essa obra
}




\section{AGRADECIMENTOS}

À Deus por ter me proporcionado chegar até aqui, com coragem, saúde e sabedoria. À minha família e companheiro Bruno Freire pelo amor e apoio incondicional.

Ao Prof. Dr. Almir Oliveira Neto pela oportunidade e dedicada orientação durante estes anos.

À CNPq, CNEN/IPEN e USP pelo incentivo financeiro e infra-estrutura.

À toda equipe do Centro de Célula a Combustível e Hidrogênio $(\mathrm{CCCH})$, como amigos e colegas de trabalho. 
"Deixe o futuro falar a verdade e classificar cada um de acordo com seu trabalho e conquista. O tempo presente é de cada um. Já o futuro, o qual eu tenho realmente trabalhado, é meu."

Nikola Tesla 


\title{
OXIDAÇÃO ELETROQUÍMICA DO METANOL EM ELETRÓLITO ALCALINO POR INTERMÉDIO DE ELETROCATALISADORES PtRuIn/C PREPARADOS PELO MÉTODO DE REDUÇÃO POR BOROHIDRETO DE SÓDIO
}

\author{
MONIQUE CAROLINA LIMA SANTOS
}

\begin{abstract}
RESUMO
Neste trabalho os diferentes sistemas eletrocatalíticos PtIn/C, PtRu/C, PtRuIn/C e suas diferentes proporções mássicas foram sintetizados pelo método de redução por Borohidreto de Sódio, a fim de serem utilizados como ânodo na célula a combustível alcalina de metanol direto (DMFC). Os materiais obtidos foram caracterizados pelas técnicas de EDX, DRX e MET. O método de redução aplicado na síntese se mostrou efetivo, uma vez que as partículas apresentaram boa dispersão no suporte de carbono Vulcan XC72, de acordo com as analises de EDX e MET. Os resultados obtidos por DRX evidenciaram em todos os difratogramas apresentados a estrutura CFC da platina e um relativo deslocamento do pico equivalente ao plano (220) para valores maiores e menores que 2Ө. O tamanho médio do cristalito e os parâmetros de rede calculados indicaram a inserção de átomos de Índio e Rutênio à estrutura da Platina, supondo a formação de ligas. A oxidação eletroquímica do metanol foi estudada por voltametria cíclica, cronoamperometria e curvas de polarização. Os experimentos eletroquímicos demonstraram que nos eletrocatalisadores binários com maior composição de Índio e Rutênio a eficiência catalítica frente a oxidação do combustível foi melhor e para os ternários, o eletrocatalisador que possuía maior composição de Rutênio se mostrou mais eficiente. Nos experimentos práticos em células a combustível, as curvas de polarização mostraram divergências de resultados com os obtidos por voltametria cíclica e cronoamperometria, justificadas por problemas de prensagem e descolamento de MEA's em sistemas que apresentaram maior quantidade de cocatalisador como Índio e Rutênio.
\end{abstract}

Palavras-chave: Eletrocatalisadores, índio, rutênio e metanol 


\title{
ELECTROCHEMICAL OXIDATION OF METHANOL IN ALKALINE ELETROLYTE BY INTERMEDIATE OF PtRuIn/C ELECTROCATALYSTS PREPARED BY SODIUM BOROHYDRIDE REDUCTION METHOD
}

\author{
MONIQUE CAROLINA LIMA SANTOS
}

\begin{abstract}
In this work the different electrocatalytic systems PtIn/C, PtRu/C, PtRuIn/C and their different mass proportions were synthesized by the sodium borohydride reduction method, in order to be used as an anode in the alkaline direct methanol fuel cell (DMFC). The obtained materials were characterized by EDX, DRX and MET techniques. The reduction method applied in the synthesis was effective, since the particles showed good dispersion in the carbon support Vulcan XC72, according to the EDX and MET analyzes. The results obtained by XRD showed in all the diffractograms presented the CFC structure of platinum and a relative displacement of the equivalent peak to the plane (220) for values greater than and less than $2 \Theta$. The mean crystallite size and the calculated net parameters indicated the insertion of Indium and Ruthenium atoms to the Platinum structure, assuming the formation of alloys. The electrochemical oxidation of methanol was studied by cyclic voltammetry, chronoamperometry and polarization curves. The electrochemical experiments showed that in the binary electrocatalysts with higher composition of Indium and Ruthenium, the catalytic efficiency against the oxidation of the fuel demonstrated a better result. Meanwhile the ternary, the electrocatalyst with the higher Ruthenium composition was more efficient. In terms of the practical experiments in fuel cells, the polarization curves showed divergences of results with those obtained by cyclic voltammetry and chronoamperometry, which can be justified by issues of pressing and detachment of MEA's in systems that presented higher amounts of cocatalysts such as Indium and Ruthenium.
\end{abstract}

Keywords: Electrocatalysts, indium, ruthenium and methanol 


\section{SUMÁRIO}

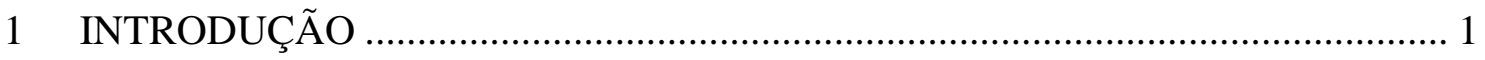

2 REVISÃO BIBLIOGRÁFICA......................................................................... 3

2.1 BREVE HISTÓRICO, FUNDAMENTOS TEÓRICOS E DESCRIÇÃO DAS

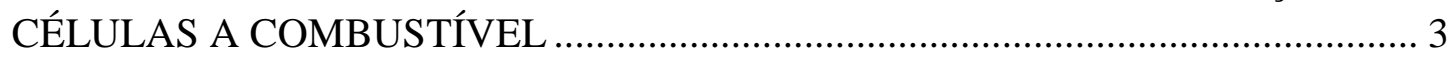

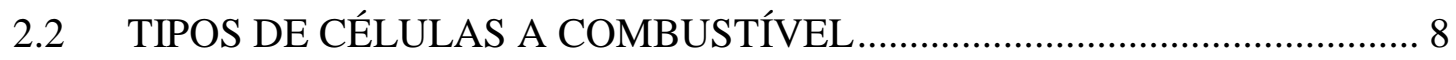

2.2.1 Célula a combustível alcalina (AFC) ....................................................... 10

2.2.2 Célula a combustível de membrana trocadora de prótons (PEMFC) ........ 13

2.3 ELETRO-OXIDAÇÃO DE METANOL E CÉLULAS DMFC........................ 19

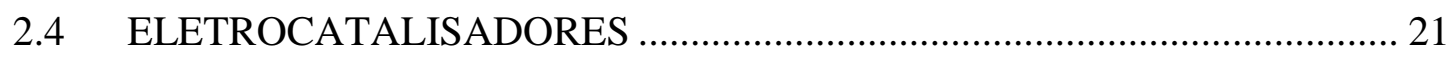

2.4.1 Mecanismo bifuncional e efeito eletrônico ............................................... 22

2.4.2 Método de redução via borohidreto de sódio ........................................... 23

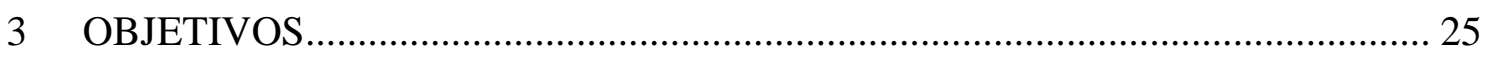

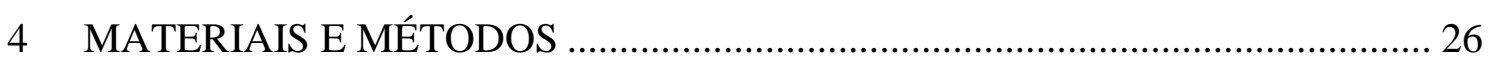

4.1 PREPARAÇÃO E CARACTERIZAÇÃO DOS ELETROCATALISADORES 26

4.2 CARACTERIZAÇÃO FÍSICO-QUÍMICA DOS

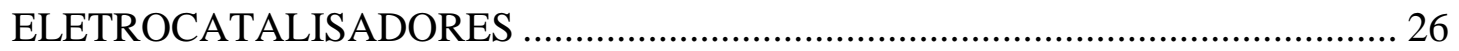

4.3 ESPECTROSCOPIA DE ENERGIA DISPERSIVA DE RAIOS-X................ 26

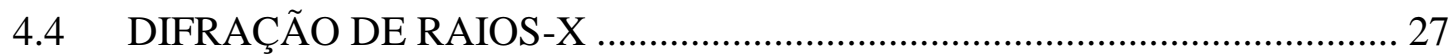

4.5 MICROSCOPIA ELETRÔNICA DE TRANSMISSÃO …………………….... 28

4.6 CARACTERIZAÇÃO ELETROQUÍMICA DOS

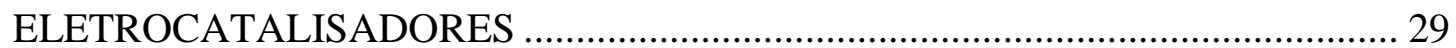

4.7 PRODUÇÃO DO CONJUNTO MEMBRANA-ELETRODO (MEA) ............ 31

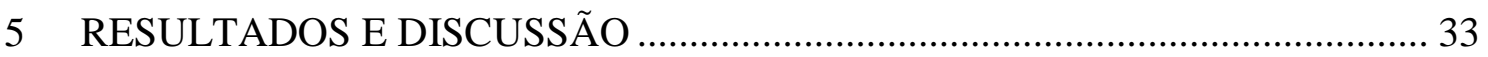

5.1 CARACTERIZAÇÃO ESTRUTURAL, MORFOLÓGICA E ELETROCATALÍTICA DOS SISTEMAS In, Pt E BINÁRIOS SUPORTADOS EM

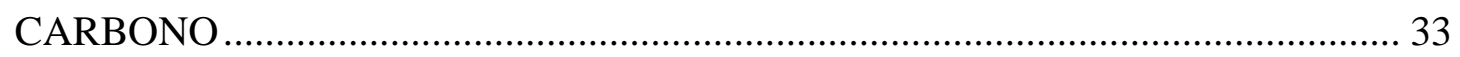

5.2 CARACTERIZAÇÃO ESTRUTURAL, MORFOLÓGICA E ELETROCATALÍTICA DOS SISTEMAS Ru, Pt E BINÁRIOS SUPORTADOS EM CARBONO. 
5.3 CARACTERIZAÇÃO ESTRUTURAL, MORFOLÓGICA E ELETROCATALÍTICA DOS SISTEMAS TERNÁRIOS PtRuIn SUPORTADOS

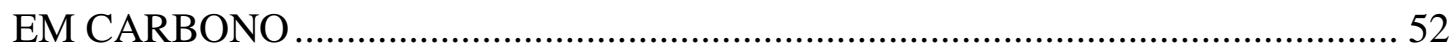

5.4 COMPARAÇÃO DOS RESULTADOS OBTIDOS POR CARACTERIZAÇÃ̃O ELETROQUÍMICA E TESTES PRÁTICOS DOS

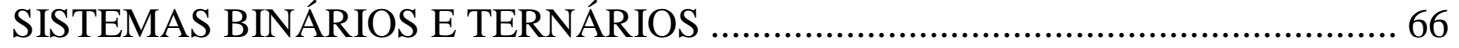

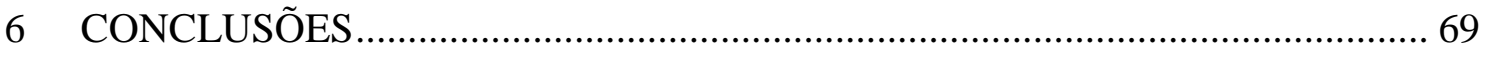

7 TRABALHOS PÚBLICADOS EM PERIÓDICOS INTERNACIONAIS ............. 70

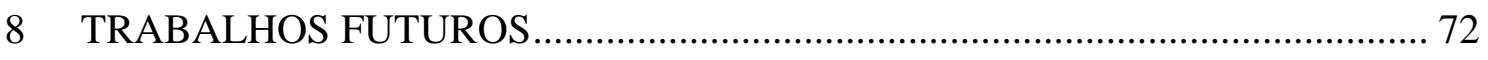

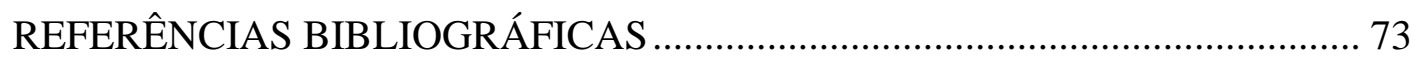




\section{LISTA DE FIGURAS}

FIGURA 1- (a) Eletrólise da água. A molécula de água é separada em hidrogênio e oxigênio pela passagem de corrente elétrica. (b) Uma pequena corrente flui. O oxigênio e o hidrogênio são recombinados, adaptado de [1].

FIGURA 2 - Representação esquemática de uma célula a combustível [14] .................. 5 FIGURA 3 - Gráfico típico da curva de polarização de uma célula a combustível do tipo PEM: (I) Região com predomínio da polarização por ativação; (II) Região com predomínio da polarização por queda ôhmica; e (III) Região com predomínio da polarização por difusão. Arquivo pessoal.

FIGURA 4 - Alterações Evolutivas no Desempenho de AFC's, adaptado de [12]....... 13 FIGURA 5 - (A) Esquema de PEMFC representativa (B) Estrutura de Célula Única do modelo PEMFC, adaptado de [12].

FIGURA 6 - Exemplo de estrutura de um flúor etileno sulfonado (também designado ácido perfluorossulfónico - PTFE) [1].

FIGURA 7 - A estrutura de um tipo de membrana Náfion ${ }^{\circledR}$. Moléculas de cadeia longa contendo regiões hidratadas em torno das cadeias laterais sulfonadas, adaptado de [1].17 FIGURA 8 - Esquema dos tipos de ligação entre $\mathrm{CO}$ e Pt A) tipo linear B) tipo ponte [14].

FIGURA 9 - Esquema simplificado para a eletro-oxidação de metanol e formação dos seus respectivos intermediários [6].

FIGURA 10 - Voltamograma característico do eletrocatalisador $\mathrm{Pt} / \mathrm{C}$, na presença de

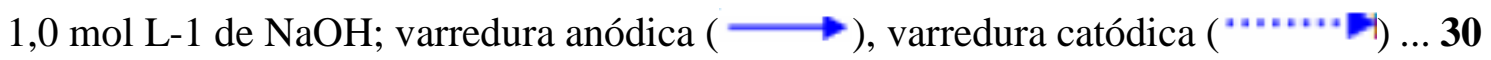
FIGURA 11 - Modelo de um eletrodo de trabalho de grafite pirolítico acoplado a um suporte de teflon utilizado para testes eletroquímicos [21].

FIGURA 12 - Difratogramas de Raios-X dos eletrocatalisadores Pt/C, PtIn/C e In/C e suas respectivas proporções, preparados pelo método de redução via Borohidreto de Sódio, em um intervalo de $2 \theta$, variando de $20^{\circ}$ a $90^{\circ}$, a uma velocidade de varredura de $2^{\circ} \min$

FIGURA 13 - Micrografias obtidas por MET dos catalisadores Pt/C e sistemas binários PtIn/C.

FIGURA 14 - Histograma da distribuição dos tamanhos das partículas dos eletrocatalisadores PtIn/C e suas diferentes composições.

FIGURA 15 - Voltamogramas para os eletrocatalisadores Pt/C, In/C, PtIn/C 50:50, PtIn/C 70:30 e PtIn/C 90:10 obtidos a uma velocidade de $10 \mathrm{mV} . \mathrm{s}^{-1}$, na presença de 1,0 mol.L ${ }^{-1}$ de $\mathrm{KOH}$.

FIGURA 16 - Voltametria cíclica para os eletrocatalisadores de Pt/C, In/C, PtIn/C 50:50, PtIn/C 70:30 e PtIn/C 90:10 obtidos a uma velocidade de $10 \mathrm{mV} . \mathrm{s}^{-1}$, na presença de 1,0 mol.L ${ }^{-1}$ de KOH e 1,0 mol.L ${ }^{-1}$ de metanol. 
FIGURA 17 - Curva cronoamperométrica para os eletrocatalisadores de $\mathrm{Pt} / \mathrm{C}, \mathrm{In} / \mathrm{C}$, PtIn/C 50:50, PtIn/C 70:30 e PtIn/C 90:10 obtidos na presença de 1,0 mol.L ${ }^{-1}$ de KOH e 1,0 mol. $\mathrm{L}^{-1}$ de metanol no potencial de $-400 \mathrm{mV}$ durante 30 minutos.

FIGURA 18 - Curvas de polarização para Pt/C, In/C, PtIn/C 50:50, PtIn/C 70:30 e PtIn/C 90:10 no ânodo, utilizando (1mg Pt cm2), ETEK Pt/C no cátodo e membrana Náfion® 117, fluxo $\sim 1 \mathrm{~mL}$ min-1 de solução de metanol (2 mol L-1), fluxo de O2 de $150 \mathrm{~mL}$ min-1, temperatura da célula: $80^{\circ} \mathrm{C}$ e temperatura de $\mathrm{H} 2, \mathrm{O} 2: 85^{\circ} \mathrm{C}$.

FIGURA 19 - Difratogramas de Raios- $X$ dos eletrocatalisadores $\mathrm{Pt} / \mathrm{C}, \mathrm{PtRu} / \mathrm{C}$ e $\mathrm{Ru} / \mathrm{C}$ e suas respectivas proporções, preparados pelo método de redução via Borohidreto de Sódio, em um intervalo de $2 \theta$, variando de $20^{\circ}$ a $90^{\circ}$, a uma velocidade de varredura de $2^{\circ} \min$.

FIGURA 20 - Micrografias obtidas por MET dos catalisadores Pt/C e sistemas binários $\mathrm{PtRu} / \mathrm{C}$. 46

FIGURA 21 - Histograma da distribuição dos tamanhos das partículas dos eletrocatalisadores $\mathrm{PtRu} / \mathrm{C}$ e suas diferentes composições.

FIGURA 22 - Voltamogramas para os eletrocatalisadores $\mathrm{Pt} / \mathrm{C}, \mathrm{Ru} / \mathrm{C}, \mathrm{PtRu} / \mathrm{C}$ 50:50, $\mathrm{PtRu} / \mathrm{C}$ 70:30 e PtRu/C 90:10 obtidos a uma velocidade de $10 \mathrm{mV} . \mathrm{s}^{-1}$, na presença de 1,0 mol.L ${ }^{-1}$ de KOH.

FIGURA 23 - Voltametria cíclica para os eletrocatalisadores de $\mathrm{Pt} / \mathrm{C}, \mathrm{Ru} / \mathrm{C}, \mathrm{PtRu} / \mathrm{C}$ 50:50, PtRu/C 70:30 e PtRu/C 90:10 obtidos a uma velocidade de $10 \mathrm{mV} . \mathrm{s}^{-1}$, na presença de 1,0 mol.L ${ }^{-1}$ de KOH e 1,0 mol. ${ }^{-1}$ de metanol.

FIGURA 24 - Curva cronoamperométrica para os eletrocatalisadores de $\mathrm{Pt} / \mathrm{C}, \mathrm{Ru} / \mathrm{C}$, $\mathrm{PtRu} / \mathrm{C}$ 50:50, PtRu/C 70:30 e PtRu/C 90:10 obtidos na presença de 1,0 mol. $\mathrm{L}^{-1}$ de KOH e 1,0 mol.L ${ }^{-1}$ de metanol no potencial de $-400 \mathrm{mV}$ durante 30 minutos.............. 50 FIGURA 25 - Curvas de polarização para Pt/C, Ru/C, PtRu/C 50:50, PtRu/C 70:30 e $\mathrm{PtRu} / \mathrm{C}$ 90:10 no ânodo utilizando $\left(1 \mathrm{mg} \mathrm{Pt} \mathrm{cm}^{2}\right)$ e ETEK Pt/C no cátodo e Nafion® 117 como membrana, a $80^{\circ} \mathrm{C}$, fluxo $\sim 1 \mathrm{~mL} \mathrm{~min}^{-1}$ de solução de metanol $\left(2 \mathrm{~mol} \mathrm{~L}^{-1}\right)$, fluxo de $\mathrm{O}_{2}$ de $150 \mathrm{~mL} \mathrm{~min}^{-1}$.

FIGURA 26 - Difratogramas de Raios- $\mathrm{X}$ dos eletrocatalisadores $\mathrm{Pt} / \mathrm{C}$ e os sistemas ternários e suas respectivas proporções, preparados pelo método de redução via Borohidreto de Sódio, em um intervalo de $2 \theta$, variando de $20^{\circ}$ a $90^{\circ}$, a uma velocidade de varredura de $2^{\circ}$ min. 53

FIGURA 27 - Espectros de distribuição dos elementos constituintes dos eletrocatalisadores obtidos por EDX: A) PtRuIn/C (50:10:40), B) PtRuIn/C (50:25:25), C) PtRuIn/C (50:40:10), D) PtRuIn/C 70:20:10 e E) PtRuIn/C 90:05:05 preparados pelo método de redução via borohidreto de sódio. Erro! Indicador não definido.57 FIGURA 28 - Micrografias obtidas por MET dos catalisadores PtRuIn/C e suas diferentes composições.

FIGURA 29 - Histograma da distribuição dos tamanhos das partículas dos eletrocatalisadores $\mathrm{Pt} / \mathrm{C}$ e PtRuIn/C e suas diferentes composições.

FIGURA 30 - Voltamogramas cíclicos com velocidade de varredura de $10 \mathrm{mV} \mathrm{s}^{-1}$, dos eletrocatalisadores Pt/C, PtRuIn/C 50:10:40, PtRuIn/C 50:25:25, PtRuIn/C 50:40:10, 
PtRuIn/C 70:20:10 e PtRuIn/C 90:05:05, em solução de KOH 1,0 mol L-1 a temperatura ambiente.

FIGURA 31 - Voltamogramas cíclicos com velocidade de varredura de $10 \mathrm{mV} \mathrm{s}$-1, dos eletrocatalisadores Pt/C, PtRuIn/C 50:10:40, PtRuIn/C 50:25:25, PtRuIn/C 50:40:10, PtRuIn/C 70:20:10 e PtRuIn/C 90:05:05, em solução de KOH 1,0 mol L-1 e 1,0 mol L1 de metanol a temperatura ambiente.

FIGURA 32 - Curva cronoamperométrica para os eletrocatalisadores de $\mathrm{Pt} / \mathrm{C}$, PtRuIn/C 50:10:40, PtRuIn/C 50:25:25, PtRuIn/C 50:40:10, PtRuIn/C 70:20:10 e PtRuIn/C 90: 05:05 obtidos na presença de 1,0 mol.L ${ }^{-1}$ de KOH e 1,0 mol.L ${ }^{-1}$ de metanol no potencial de $-400 \mathrm{mV}$ durante 30 minutos 63

FIGURA 33 - Curvas de polarização para Pt/C, PtRuIn/C 50:10:40, PtRuIn/C 50:25:25, PtRuIn/C 50:40:10, PtRuIn/C 70:20:10 e PtRuIn/C 90:05:05, fluxo $1 \mathrm{~mL} \mathrm{~min}^{-1}$ de solução de metanol $\left(2 \mathrm{~mol} \mathrm{~L}^{-1}\right)$, fluxo de $\mathrm{O}_{2}$ de $150 \mathrm{~mL} \mathrm{~min}^{-1}$, temperatura da célula: $80^{\circ} \mathrm{C}$ e temperatura de $\mathrm{H}_{2}, \mathrm{O}_{2}: 85^{\circ} \mathrm{C}$ 


\section{LISTA DE TABELAS}

TABELA 1 - Tipos principais de células a combustível [17]

TABELA 2 - Razões atômicas nominais, relação atômica de EDX (mol \%), parâmetro de rede e tamanho médio de cristalito dos eletrocatalisadores $\mathrm{Pt} / \mathrm{C}$ e PtIn/C preparados pelo método do Borohidreto.

TABELA 3 - Razões atômicas nominais, relação atômica de EDX (mol \%), parâmetro de rede e tamanho médio de cristalito dos eletrocatalisadores $\mathrm{Pt} / \mathrm{C}$ e $\mathrm{PtRu} / \mathrm{C}$ preparados pelo método do Borohidreto. 45

TABELA 4 - Razões atômicas nominais, relação atômica de EDX (mol \%), parâmetro de rede e tamanho médio de cristalito dos eletrocatalisadores $\mathrm{Pt} / \mathrm{C}$ e os sistemas ternários PtRuIn/C preparados pelo método de redução via Borohidreto de Sódio.

TABELA 5 - Tabela de resultados comparativos de cronoamperometria e teste em célula de todos os eletrocatalisadores sintetizados via Borohidreto de Sódio. 


\section{LISTA DE ABREVIATURAS E SIGLAS}

USP - Universidade de São Paulo

IPEN - Instituto de Pesquisas Energéticas e Nucleares - (IPEN-CNEN/SP)

$\mathrm{CCCH}$ - Centro de Células a Combustível e Hidrogênio

EDX - Espectroscopia de Energia Dispersiva de Raios-X

DRX - Difração De Raios-X

MET - Microscopia Eletrônica de Transmissão

MEA - "Membrane Electrode Assembly" (Conjunto eletrodos-Membrana)

PEMFC - "Proton Exchange Membrane Fuel Cell" (Células a Combustível de

Membrana Trocadora de Prótons)

ROH - Reação de Oxidação de Hidrogênio

RRO - Reação de Redução de Oxigênio

DMFC - "Direct Methanol Fuel Cell" (Células a Combustível a Metanol Direto)

DEFC - "Direct Ethanol Fuel Cell" (Células a Combustível a Etanol Direto)

$\mathrm{CO}$ - Monóxido de Carbono

AFC - "Alkaline Fuel Cell" (Células a Combustível Alcalina)

kW - Kilowatt

GDL - "Gas Diffusion Layer" (Camada Difusora de Gás)

${ }^{\circ} \mathrm{C}$ - Grau Celsius

PAFC - "Phosphoric Acid Fuel Cell" (Células a Combustível de Ácido Fosfórico)

MCFC - "Molten Carbonate Fuel Cell" (Células a Combustível de Carbonato Fundido)

SOFC - "Solid Oxide Fuel Cell" (Células a Combustível de Óxido Sólido)

$\mathrm{N}_{2} \mathrm{H}_{4}$ - Hidrazina

$\mathrm{NH}_{3}-$ Amônia

AAEMFC - "Alkaline Anion Exchange Membrane Fuel Cell" (Células a Combustível de Membrana Alcalina Aniônica)

AEM - "Anion Exchange Membrane" (Membrana Trocadora de Ânions)

$\mathrm{CO}_{2}$ - Dióxido de Carbono

$\mathrm{H}_{2} \mathrm{CO}_{3}$ - Ácido Carbônico

PTFE - Politetrafluoretileno

$\mathrm{Kg}$ - Quilograma

$\mathrm{eV}$ - Elétron-Volt

$\mathrm{NaBH}_{4}-$ Borohidreto de Sódio 


\section{INTRODUÇÃO}

Os recursos energéticos são considerados cada vez mais o foco de grandes governos, uma vez que com o aumento populacional e a industrialização se demanda de alta quantidade de energia, o que por sua vez gera conflitos entre os países considerados potencias econômicas. A matriz energética sustentada em sua maior parte por combustíveis fósseis e não renováveis, perde credibilidade por causar diversos problemas ambientais, males a saúde e até alterações climáticas que contribuem para o aquecimento global [1]. Diante desse cenário a busca por fontes alternativas renováveis e menos poluentes se tornou de extrema importância, motivando assim a procura por novos estudos e rotas de pesquisa para obtenção de energia elétrica [2], sendo o uso de células a combustível uma alternativa promissora no setor energético [3].

O estudo e a invenção das células a combustível foi atribuída a William Grove em 1839 [1], sendo ao longo das décadas muitos recursos investidos em seu desenvolvimento. A tecnologia trata-se de sistemas eletroquímicos capazes de transformar a energia química de um combustível abastecido de um provedor externo de forma continua em energia elétrica e calor [2]. A conversão de energia que ocorre neste sistema pode ser executada de forma direta, ação que favorece um aproveitamento mais efetivo do que quando comparada a sistemas que operam indiretamente [3].

Dentre diversos tipos de células a combustível existentes, as células que utilizam eletrólito polimérico alimentadas com hidrogênio puro $\left(\mathrm{H}_{2}\right)$ são denominadas PEMFC (Próton Exchange Membrane Fuel Cell), e se baseiam na reação de oxidação do hidrogênio (ROH) e na de redução do oxigênio (RRO), que são tidas como mais eficientes atualmente [1]. Consideradas as mais usuais, essas células, por utilizarem o $\mathrm{H}_{2}$ que possui característica explosiva e alto custo, apresentam dificuldades quanto ao transporte e manuseio assim como sua obtenção por meio da eletrólise da água [4,5]. Portanto, melhorias a respeito da escolha do combustível precisavam ser feitas, sendo as mais adequadas para utilização em aplicações móveis o uso de combustíveis líquido direto, como as alimentadas com etanol e metanol (DMFC E DEFC - Direct Methanol/Ethanol Fuel Cell), por questões de propriedades e armazenagem, assim como a densidade de energia [2]. Contudo, a DMFC apresenta um terço de desempenho de uma PEMFC abastecida com hidrogênio puro, por exemplo, isso porque o mecanismo reacional e sua 
oxidação ocorre de forma mais lenta que a do hidrogênio. Adicionalmente ocorrendo sua permeabilidade no eletrólito polimérico, também chamado de efeito crossover, onde o combustível é oxidado por vias não eletroquímicas no cátodo reduzindo seu desempenho [6]. O eletrocatalisador de platina disperso em carbono $(\mathrm{Pt} / \mathrm{C})$ é o de excelência para processos eletroquímicos de oxidação e redução de uma célula alimentada por $\mathrm{H}_{2} / \mathrm{O}_{2}$, desde que seus reagentes apresentem alto nível de pureza. Entretanto, para o $\mathrm{H}_{2}$ proveniente de reforma de outros compostos orgânicos como metanol [7], etanol [8] e ácido fórmico [9], é presente em sua composição traços de CO que atuam como veneno catalítico diminuindo a eficiência energética do sistema.

Atualmente o estágio de pesquisas direcionadas para essa tecnologia sugere o uso de ligas de Platina com metais de transição como Rutênio, Molibdênio e Estanho, os quais são considerados mais ativos para reação de oxidação de hidrogênio contaminado com CO. Veizaga e colaboradores [10] produziram PtIn/C para emprego no ânodo em células a combustível alimentadas diretamente por metanol (DMFC) em meio ácido e observaram que estes eletrocatalisadores foram mais ativos para a oxidação do álcool, comparados ao que constituía somente Pt. De acordo com os autores citados, a presença de Índio facilita o mecanismo da reação de oxidação de forma semelhante ao $\mathrm{PtRu} / \mathrm{C}$, o que impulsionou o interesse deste trabalho à síntese de eletrocatalisadores PtIn/C e PtRuIn/C bem como avaliar a performance dos elementos Índio e Rutênio na condição de cocatalisadores.

Portanto, o presente estudo tem por finalidade avaliar a eficácia de sistemas binários tais como $\mathrm{PtIn} / \mathrm{C}, \mathrm{PtRu} / \mathrm{C}$ e ternários $\mathrm{PtRuIn/C}$, sintetizados em diferentes proporções das já vistas em literatura, para emprego na avaliação da oxidação eletroquímica do metanol em meio alcalino. Avaliar o método de síntese, mecanismo da eletro-oxidação do combustível e formação de liga para obtenção de comportamento satisfatório quanto ao efeito catalítico. 


\section{REVISÃO BIBLIOGRÁFICA}

\subsection{BREVE HISTÓRICO, FUNDAMENTOS TEÓRICOS E DESCRIÇÃO DAS CÉLULAS A COMBUSTÍVEL}

A ideia de converter combustível em eletricidade por um sistema utilizando eletrodo-eletrólito foi originada no século XIX e atribuída a Grove no ano de 1839 [1,4]. Dando continuidade a essa ideia, na primeira metade do século $\mathrm{XX}$, mais precisamente em 1932, Francis T. Bacon desenvolveu uma célula à combustível alcalina (AFC - Alkaline Fuel Cell) e a apresentou em 1959 [11]. No mesmo ano, Harry K. Ihrig (Allis-Chalmers), demonstrou o primeiro veículo movido a base de uma célula a combustível alcalina, um trator motorizado de $15 \mathrm{~kW}$ [11]. Já nos anos 60 e 70 esses sistemas eletroquímicos foram aplicados em programas espaciais, sendo a AFC no programa Apollo e a célula a combustível de eletrólito polimérico (PEMFC) como fonte de alimentação auxiliar no vôo espacial Gemini [11]. Apesar da promissoriedade do dispositivo, só com a primeira crise do petróleo no inicio da década de 1970, que sua eficiência energética foi novamente questionada e a tecnologia melhor difundida nos anos seguintes.

A demonstração da operação básica da célula de combustível de hidrogênio executada por Grove [1] é ilustrada na FIG. 1 a seguir, em que a reação de eletrólise utiliza a eletricidade para decompor a água em oxigênio e hidrogênio e poderia ser realizada no sentido inverso com o uso de um catalisador adequado para produzir energia. 


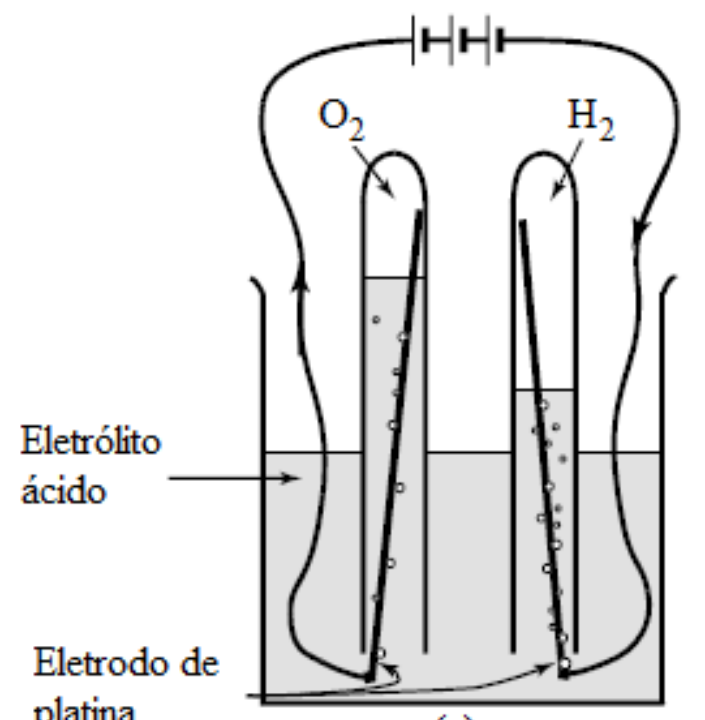

(a)

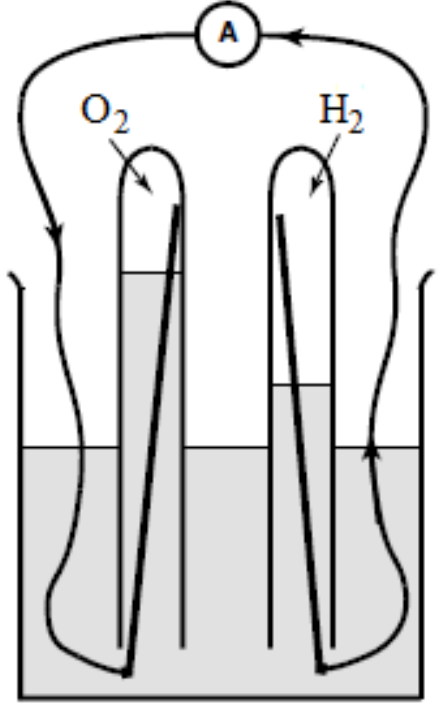

(b)

FIGURA 1- (a) Eletrólise da água. A molécula de água é separada em hidrogênio e oxigênio pela passagem de corrente elétrica. (b) Uma pequena corrente flui. O oxigênio e o hidrogênio são recombinados, adaptado de [1].

A FIG. 1 mostra o princípio básico da célula a combustível. A reação produz baixos valores de corrente e fatores como a menor área de contato entre o gás, o eletrodo e o eletrólito além da distância entre os eletrodos (faz com que haja resistência ao fluxo de energia elétrica) justificam essa perda [1].

Após anos de estudos e desenvolvimento, as células a combustível começaram a ser definidas como dispositivos eletroquímicos que convertem energia química proveniente de combustíveis $\left(\mathrm{H}_{2}\right.$, como ilustrado na FIG. 1), em energia elétrica diretamente, prometendo alta densidade de potência com baixo impacto ambiental. No entanto, ao contrário de baterias e pilhas, o redutor e o oxidante desses dispositivos devem ser continuamente reabastecidos para permitir operação contínua. Uma das grandes vantagens é o processamento de uma grande variedade de combustíveis e oxidantes, sendo de maior interesse os combustíveis comuns (ou seus derivados) ou hidrogênio como redutor e o ar ambiente como oxidante [12], além da alta eficiência e baixas emissões, que são fatores também atraentes por sua natureza modular e distribuída, mínima poluição sonora e por desenvolverem um papel essencial na economia do hidrogênio [13]. 
Os componentes primários e fundamentais que compõem uma célula à combustível são o eletrólito condutor de íons, um cátodo e um ânodo, como mostrado esquematicamente na FIG. 2 a seguir.

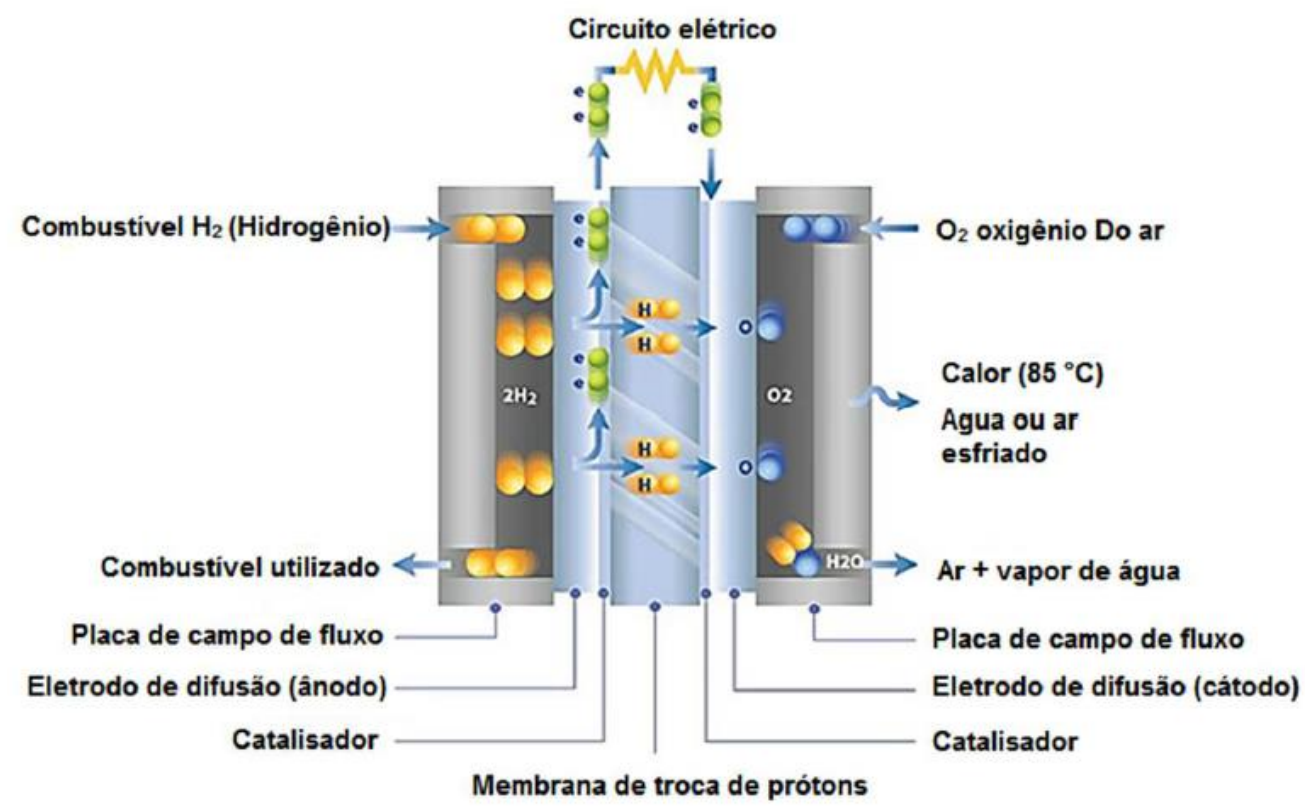

FIGURA 2 - Representação esquemática de uma célula a combustível [14].

Juntos, estes três são frequentemente referidos como o conjunto membranaeletrodo (MEA), ou simplesmente uma pilha de combustível de célula única. No exemplo mais simples, um combustível, tal como hidrogênio, é introduzido no compartimento anódico e um oxidante, tipicamente oxigênio, no compartimento catódico. Existe uma força motriz química global para que o oxigênio e o hidrogênio reajam para produzir água. A combustão química direta é impedida pelo eletrólito que separa o combustível $\left(\mathrm{H}_{2}\right)$ do oxidante $\left(\mathrm{O}_{2}\right)$. $\mathrm{O}$ eletrólito serve como uma barreira à difusão de gás, porém, permite a migração de íons por meio dele. Consequentemente, as reações de meia célula ocorrem no ânodo e no cátodo, produzindo íons que podem atravessar o eletrólito. Por exemplo, se o eletrólito conduzir íons de óxido, o oxigênio será eletro-reduzido no cátodo para produzir íons e consumir elétrons, enquanto que íons de óxido, depois de migrar por meio do eletrólito, reagirão no cátodo com hidrogênio e liberarão elétrons. O fluxo de carga iônica por meio do eletrólito deve ser equilibrado pelo fluxo de carga eletrônica através de um 
circuito externo, e é esse equilíbrio que produz energia elétrica [13,15]. As reações de meia célula que ocorrem são exemplificadas a seguir:

Reação anódica: $\mathrm{H}_{2}+2 \mathrm{H}_{2} \mathrm{O} \rightarrow 2 \mathrm{H}_{3} \mathrm{O}^{+}+2 \mathrm{e}^{-}$

Reação catódica: $1 / 2 \mathrm{O}_{2}+2 \mathrm{H}_{3} \mathrm{O}^{+}+2 \mathrm{e}^{-} \rightarrow 3 \mathrm{H}_{2} \mathrm{O}$

Reação global: combustível $+(\mathrm{x}+\mathrm{y} / 2) \mathrm{O}_{2} \rightarrow \mathrm{x} \mathrm{CO}_{2}+\mathrm{y} \mathrm{H}_{2} \mathrm{O}$

O hidrogênio $\left(\mathrm{H}_{2}\right)$ é uma molécula relativamente estável e também os combustíveis carbonosos. Devido à força da ligação $\mathrm{H}-\mathrm{H}$ ou da energia de ligação de $\mathrm{H}_{2}$, respectivamente, de aproximadamente $430 \mathrm{~kJ} / \mathrm{mol}$, apenas a ativação catalítica desta molécula aumentaria a sua reação à temperatura ambiente num grau, o que lhe permite reagir com uma taxa considerável. Para a ligação dupla da molécula de oxigênio mais fortemente ligada $(\Delta \mathrm{H}=500 \mathrm{~kJ} / \mathrm{mol})$, a ativação catalítica é ainda mais necessária. Esta afirmação é válida para as reações em fase gasosa (Reação 3), bem como para a conversão eletroquímica nas superfícies dos elétrodos (Reações 1 e 2) [16].

O MEA (conjunto eletrodo membrana) é depositado entre duas placas de campo de fluxo que são muitas vezes espelhadas para fazer uma placa bipolar quando as células são empilhadas em série para tensões maiores. $\mathrm{O}$ mesmo consiste em uma membrana de troca de prótons, camadas de catalisador e camadas de difusão de gás (GDL Gás Diffusion Layer). Tipicamente, estes componentes são fabricados individualmente e depois prensados em conjunto a altas temperaturas e pressões [15].

No caso de células do tipo módulos (empilhamento, "stack"), incluem-se as placas bipolares ou interconectores que ligam em série, o ânodo de uma célula ao cátodo de outra, esses componentes devem possuir alta resistência à atmosfera redutora e oxidante, além de serem bons condutores eletrônicos. Em outros casos se faz o uso de sistema operacional (no caso de módulos), sistema de processamento de combustível (reforma), vedações, trocadores de calor, inversor, etc [17].

Conforme citado anteriormente, a injeção continua de gases reagentes na célula do tipo PEM, cria uma diferença de potencial entre os eletrodos e uma força eletromotriz decorrente, capaz de gerar correntes elétricas. Entretanto, com o escoamento das cargas elétricas, perdas de potencial elétrico ocorrem em decorrência de barreiras energéticas a serem rompidas para que as reações eletroquímicas ocorram. Se, por alguma causa, o 
potencial elétrico do eletrodo se afastar do potencial de equilíbrio desejado para a célula, diz-se que o eletrodo sofreu polarização em que a medida de polarização é denominada de sobrepotencial. Em cinética química, é de importância fundamental determinar que a densidade de corrente varia com o sobrepotencial (ou sobretensão) da célula.

O sobrepotencial total de uma célula a combustível pode ser compreendido como um somatório das contribuições individuais de diversos sobrepotenciais, cada qual relacionado a um fenômeno físico-químico que ocorre quando existe a passagem de corrente elétrica na interface eletrodo/eletrólito, conforme a equação 1.

$$
\eta \text { total }=\eta A+\eta C+\eta R
$$

Onde $\prod A$ é a polarização por ativação, que representa a barreira energética criada para a transferência de elétrons na interface do eletrodo/solução, $\rceil C$ é a polarização por difusão (ou transferência de massa), caracterizada pela resistência à difusão de espécies envolvidas na reação até a interface do eletrodo e $\eta R$ é a polarização por queda ôhmica, relacionada a resistência ôhmica dos componentes da célula, em especial, a resistência ao transporte dos íons hidrogênio $\left(\mathrm{H}^{+}\right)$e ao transporte de elétrons pelas placas condutoras e pelo circuito externo [17].

Experimentalmente, o desempenho da célula é dado por sua curva característica do estudo em questão. Esta curva representa a queda do potencial elétrico da célula, a partir do potencial de circuito aberto, em razão do aumento de solicitação de carga, ou seja, é um gráfico do potencial elétrico em função da densidade de corrente. Para baixas densidades, tem-se que as polarizações por difusão e por queda ôhmica são desprezíveis e, portanto, o comportamento do sistema, passa a ser determinado, em especial, pela polarização por ativação, ou seja, o sobrepotencial principal provem da resistência à transferência de cargas na superfície do eletrodo [17]. Na FIG. 3, tem-se uma curva de polarização característica. 


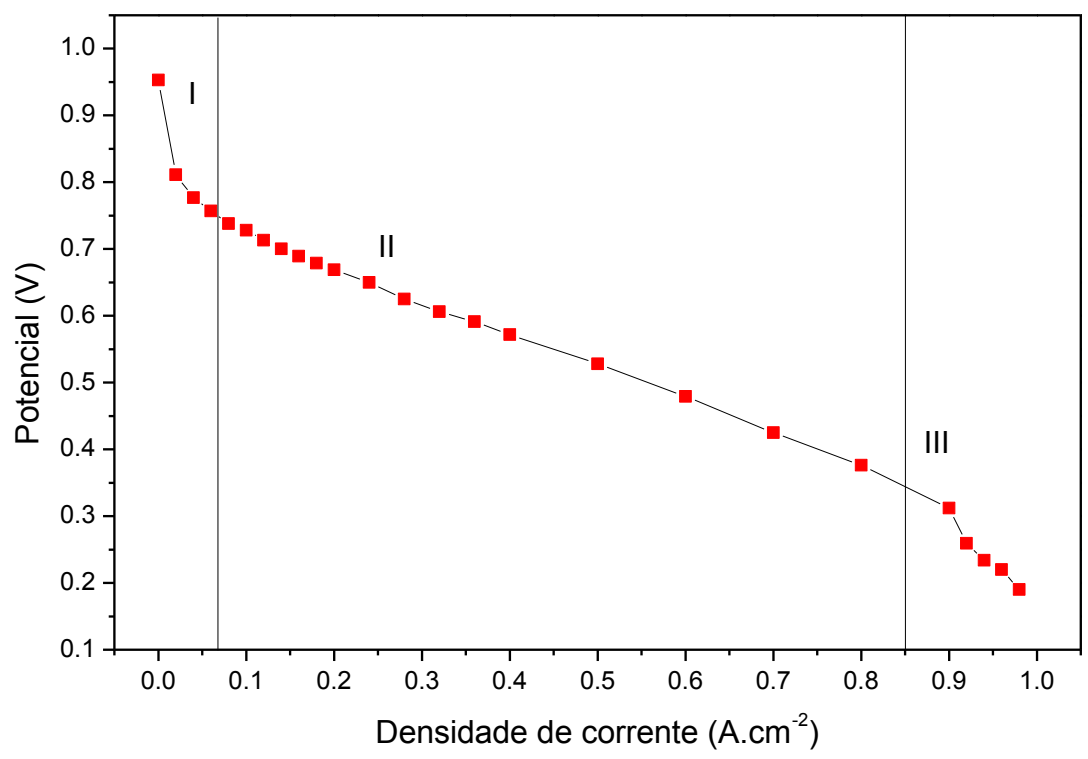

FIGURA 3 - Gráfico típico da curva de polarização de uma célula a combustível do tipo PEM: (I) Região com predomínio da polarização por ativação; (II) Região com predomínio da polarização por queda ôhmica; e (III) Região com predomínio da polarização por difusão. Arquivo pessoal.

\subsection{TIPOS DE CÉLULAS A COMBUSTÍVEL}

Existem vários tipos de células a combustível, são classificadas de acordo com o tipo de eletrólito em que é empregado em seu interior e a temperatura em que operam. As aplicações alcançadas por estes dispositivos eletroquímicos compreendem desde portáteis, estacionários até espaciais. Destacam-se dois grupos de células principais, nesta classificação: as de baixa temperatura e as de alta temperatura de operação que são citadas a seguir respectivamente [17]. As células de baixa temperatura de operação (temperatura de operação entre a temperatura ambiente até $200^{\circ} \mathrm{C}$ ) incluem: células alcalinas (AFC Alkaline Fuel Cell), célula a combustível de membrana polimérica trocadora de prótons (PEMFC - Proton Exchange Membrane Fuel Cell) (ambas serão discutidas com maior ênfase por serem foco deste estudo, nos capítulos posteriores) e a célula a ácido fosfórico (PAFC - Phosphoric Acid Fuel Cell). Dentre as células de alta temperatura de operação (temperatura de operação superior a $200^{\circ} \mathrm{C}$ ) encontram-se as células a carbonato fundido (MCFC - Molten Carbonate Fuel Cell) e as células cerâmicas (SOFC - Solid Oxide Fuel Cell) $[1,2,12]$. A TAB. 1 descreve os íons transportados para os tipos de célula citados, 
segundo seu eletrólito específico, faixa de temperatura de operação, suas vantagens, desvantagens e aplicações.

TABELA 1 - Tipos principais de células a combustível [17].

\begin{tabular}{|c|c|c|c|c|c|}
\hline Tipo & $\begin{array}{l}\text { Eletrólito } \\
\text { (Espécie } \\
\text { transportada) }\end{array}$ & $\begin{array}{l}\text { Faixa de } \\
\text { temperatura } \\
\left({ }^{\circ} \mathrm{C}\right)\end{array}$ & $\begin{array}{l}\text { Principais } \\
\text { vantagens }\end{array}$ & $\begin{array}{l}\text { Principais } \\
\text { desvantagens }\end{array}$ & Aplicações \\
\hline $\begin{array}{l}\text { Alcalina } \\
\text { AFC }\end{array}$ & $\mathrm{KOH}\left(\mathrm{OH}^{-}\right)$ & $60-90$ & Alta eficiência & $\begin{array}{l}\text { Sensível a } \mathrm{CO}_{2} \\
\text { Remoção de } \\
\text { água } \\
\text { Gases ultrapuros }\end{array}$ & $\begin{array}{l}\text { Espaçonaves } \\
\text { Aplicações } \\
\text { especiais }\end{array}$ \\
\hline $\begin{array}{l}\text { Membrana } \\
\text { PEMFC }\end{array}$ & $\begin{array}{l}\text { Polímero: } \\
\text { Náfion }\left(\mathrm{H}_{3} \mathrm{O}^{+}\right)\end{array}$ & $80-90$ & $\begin{array}{l}\text { Altas densidades de } \\
\text { potência e } \\
\text { eficiências } \\
\text { Operação flexível } \\
\text { Robustas }\end{array}$ & $\begin{array}{l}\text { Custo da } \\
\text { membrana e } \\
\text { catalisador } \\
\text { Contaminação } \\
\text { da Pt por CO }\end{array}$ & $\begin{array}{l}\text { Veículos } \\
\text { Espaçonaves } \\
\text { Unidades } \\
\text { estacionárias }\end{array}$ \\
\hline $\begin{array}{l}\text { Ácido } \\
\text { fosfórico } \\
\text { PAFC }\end{array}$ & $\mathrm{H}_{3} \mathrm{PO}_{4}\left(\mathrm{H}_{3} \mathrm{O}^{+}\right)$ & $160-200$ & $\begin{array}{l}\text { Maior } \\
\text { desenvolvimento } \\
\text { tecnológico }\end{array}$ & $\begin{array}{l}\text { Controle da } \\
\text { porosidade do } \\
\text { eletrodo } \\
\text { Alta } \\
\text { sensibilidade a } \\
\text { CO }\end{array}$ & $\begin{array}{l}\text { Unidades } \\
\text { estacionárias } \\
\text { Cogeração } \\
\text { eletricidade/ca } \\
\text { lor }\end{array}$ \\
\hline $\begin{array}{l}\text { Carbonatos } \\
\text { fundidos } \\
\text { MCFC }\end{array}$ & $\begin{array}{l}\text { Carbonatos } \\
\text { fundidos }\left(\mathrm{CO}_{3}{ }^{2-}\right)\end{array}$ & $650-700$ & $\begin{array}{l}\text { Tolerância a } \\
\mathrm{CO} / \mathrm{CO}_{2} \\
\text { Reforma interna na } \\
\text { célula }\end{array}$ & $\begin{array}{l}\text { Problemas de } \\
\text { materiais } \\
\text { Necessidade da } \\
\text { reciclagem de } \\
\mathrm{CO}_{2}\end{array}$ & $\begin{array}{l}\text { Unidades } \\
\text { estacionárias } \\
\text { Cogeração } \\
\text { eletricidade/ca } \\
\text { lor }\end{array}$ \\
\hline $\begin{array}{l}\text { Cerâmicas } \\
\text { SOFC }\end{array}$ & $\mathrm{ZrO}_{2}\left(\mathrm{O}^{2-}\right)$ & $800-1000$ & $\begin{array}{l}\text { Alta eficiência } \\
\text { Cinética favorável }\end{array}$ & $\begin{array}{l}\text { Problemas de } \\
\text { materiais } \\
\text { Necessidade de } \\
\text { pré-reforma }\end{array}$ & $\begin{array}{l}\text { Unidades } \\
\text { estacionárias } \\
\text { Cogeração }\end{array}$ \\
\hline
\end{tabular}

Os tipos de células conhecidas são constituídas por diferentes tipos de materiais e por consequência empregam diversas técnicas de construção que englobam a construção de eletrodos, bem como a operação e a manutenção dos sistemas. Em sistemas que funcionam a baixas temperaturas o eletrólito pode ser ácido, alcalino ou uma membrana condutora de íons. Já em sistemas que empregam altas temperaturas, o eletrólito utilizado pode ser o óxido sólido ou carbonato fundido $[1,12]$.

$\mathrm{O}$ potencial de equilíbrio (circuito aberto) da reação de formação de $\mathrm{H}_{2} \mathrm{O}$ é aproximadamente $1,2 \mathrm{~V}$, à temperatura ambiente. Sob solicitação de carga uma célula pode fornecer uma tensão contínua entre 0,6 e 1,0V para densidades de potência que variam conforme o tipo de célula, entre 0,15 e 1,0 A.cm ${ }^{-2}$ [3]. 


\subsubsection{Célula a combustível alcalina (AFC)}

Um grande interesse tem sido direcionado a células a combustíveis alcalinas, que utilizam membrana trocadora de ânions, por apresentarem vantagens como a alta densidade de corrente, estabilidade, cinética de oxidação anódica melhorada e polarização reduzida se destacam quando comparadas as PEMFC [18]. As células que operam usando a condução de $\mathrm{OH}^{-}$oferecem uma série de características como:

- Pertencer ao grupo de células de baixa temperatura, que funcionam entre as faixas de 60 a $90^{\circ} \mathrm{C}$ e pressões que variam de 1 a 4 atm;

- A utilização de combustíveis líquidos como a hidrazina $\left(\mathrm{N}_{2} \mathrm{H}_{4}\right)$ ou ainda a amônia $\left(\mathrm{NH}_{3}\right)$, devido ao caráter alcalino do meio reacional;

- Possuir eficiências elétricas elevadas, da ordem de $70 \%$, devido a cinética da reação de redução de oxigênio favorecida em meio alcalino. Portanto, sendo considerada a célula mais eficiente quando comparada aos outros tipos;

- Poder ficar desligada por um período de tempo prolongado;

- Utilizar eletrodos de difusão gasosa com platina, em ambos os eletrodos, sobre negro-de-fumo [17].

As células alcalinas são categorizadas dependendo de sua pressão, temperatura e estrutura do elétrodo que varia extensamente entre diferentes protótipos [1,19].

O eletrólito a ser utilizado obviamente precisa ser uma solução alcalina. Hidróxido de sódio e hidróxido de potássio (utilizados em concentrações de 3 a 45\%) [17] são os principais candidatos, uma vez que são os de menor custo, altamente solúveis e não excessivamente corrosivos. Além de melhor condutância, o carbonato de potássio é muito mais solúvel do que o carbonato de sódio, tratando-se de uma vantagem a mais dada a utilização de $\mathrm{KOH}$. Entretanto, o eletrólito trata-se do único fator comum entre diferentes tipos de AFC's. [1].

Neste tipo de protótipo as reações de meia-célula são:

Ânodo: $2 \mathrm{H}_{2}+4 \mathrm{OH}^{-} \rightarrow 4 \mathrm{H}_{2} \mathrm{O}+4 \mathrm{e}^{-}$

Os elétrons liberados nessa reação passam pelo circuito externo, atingindo o cátodo, onde reagem, formando novos íons $\mathrm{OH}^{-}$: 
Os íons hidroxila, $\mathrm{OH}^{-}$, são as espécies condutoras no eletrólito. A reação global equivalente é:

$2 \mathrm{H}_{2}+\mathrm{O}_{2} \rightarrow \mathrm{H}_{2} \mathrm{O}+$ energia elétrica + calor

Uma vez que o KOH tem a maior condutância entre os hidróxidos alcalinos, é o eletrólito de maior preferência [12].

Apesar do carbonato de potássio ser mais solúvel, a principal limitação de operação para as células alcalinas é justamente a carbonatação e a formação de precipitado decorrente desse processo. No caso das células a combustível de membrana trocadora de ânions alcalina (AAEMFCs - Alkaline Anion Exchange Membrane Fuel Cells), o uso de uma solução alcalina não se faz necessário [20]. O maior desafio no desenvolvimento das AAEMFCs são as AEMs propriamente, e sua fabricação com alta condutividade do íon $\mathrm{OH}^{-}$e estabilidade mecânica sem deterioração química em altos valores de $\mathrm{pH}$ e temperatura [21]. O uso dessas membranas diminui grandemente o efeito da carbonatação, entretanto, existe ainda a possibilidade de que o $\mathrm{CO}_{2}$ do ar se dissolva na solução aquosa e/ou na membrana para formar $\mathrm{H}_{2} \mathrm{CO}_{3}$ e que o mesmo se dissocie em $\mathrm{HCO}^{3-}$ e $\mathrm{CO}_{3}{ }^{2-}$ em baixas concentrações [20].

Dentro da categoria de células alcalinas existem diferentes tipos tais como: a célula alcalina de eletrólito móvel, célula alcalina de eletrólito estático e a célula alcalina de eletrólito dissolvido $[1,12]$. Neste estudo, será empregado o uso da célula alcalina do tipo eletrólito móvel, portanto, seu funcionamento será melhor discutido a seguir.

\subsubsection{Célula alcalina eletrólito móvel}

$\mathrm{Na}$ estrutura básica da célula à combustível eletrolítica móvel a solução de $\mathrm{KOH}$ é bombeada em torno da célula. $\mathrm{O}$ hidrogênio é fornecido ao ânodo, mas deve ser circulado, como é no ânodo onde a água é produzida. O hidrogénio evapora a água, que é então condensada na unidade de arrefecimento através da qual o hidrogénio é circulado. $\mathrm{O}$ combustível provém de um cilindro de gás comprimido e a circulação é obtida usando um circulador ejetor, o que pode ser feito também por uma bomba em outros sistemas. A maioria das células das AFC's são deste tipo. A principal vantagem do eletrólito móvel é 
que ele permite sua remoção e substituição de vez em quando. Isto é necessário porque, assim como as reações desejadas das células de combustível 4 e 5 citadas anteriormente, o dióxido de carbono no ar reagirá com o eletrólito de hidróxido de potássio, conforme a reação 7 a seguir, que por sua vez reage produzindo carbonato de potássio.

$$
2 \mathrm{KOH}+\mathrm{CO}_{2} \rightarrow \mathrm{K}_{2} \mathrm{CO}_{3}+\mathrm{H}_{2} \mathrm{O}
$$

$\mathrm{O}$ efeito disto é que a concentração de íons $\mathrm{OH}^{-}$se reduz à medida que são substituídos por íons carbonato $\mathrm{CO}_{3}{ }^{2-}$, fator que afeta significativamente o desempenho da célula. Uma maneira de reduzi-la é remover o $\mathrm{CO}_{2}$ do ar tanto quanto possível utilizando um depurador de dióxido de carbono no sistema de suprimento de ar do cátodo. No entanto, é impossível remover todo o dióxido de carbono, de modo que o eletrólito inevitavelmente se deteriorará e necessitará ser substituído em algum momento. Este sistema móvel é eficaz por ser de fácil desenvolvimento, além do custo da solução de hidróxido de potássio ser viável [1].

\subsubsection{Desempenho}

O desempenho das AFC's sofreram muitas mudanças desde 1960. A FIG.4 mostra o desempenho $\mathrm{H}_{2} /$ ar como linhas contínuas e o desempenho $\mathrm{H}_{2} / \mathrm{O}_{2}$ como linhas tracejadas. As primeiras células alcalinas operaram a temperaturas e pressões relativamente altas como requisitos em aplicações espaciais. Com o passar dos anos, e o foco principal da tecnologia se direcionou a aplicações terrestres, os componentes de baixo custo necessitavam que as temperaturas e pressões fossem desejáveis ao ar como oxidante. Esta mudança nas condições operacionais das células a combustível com respeito ao seu desempenho são mostradas na FIG. 4 abaixo [12]. 


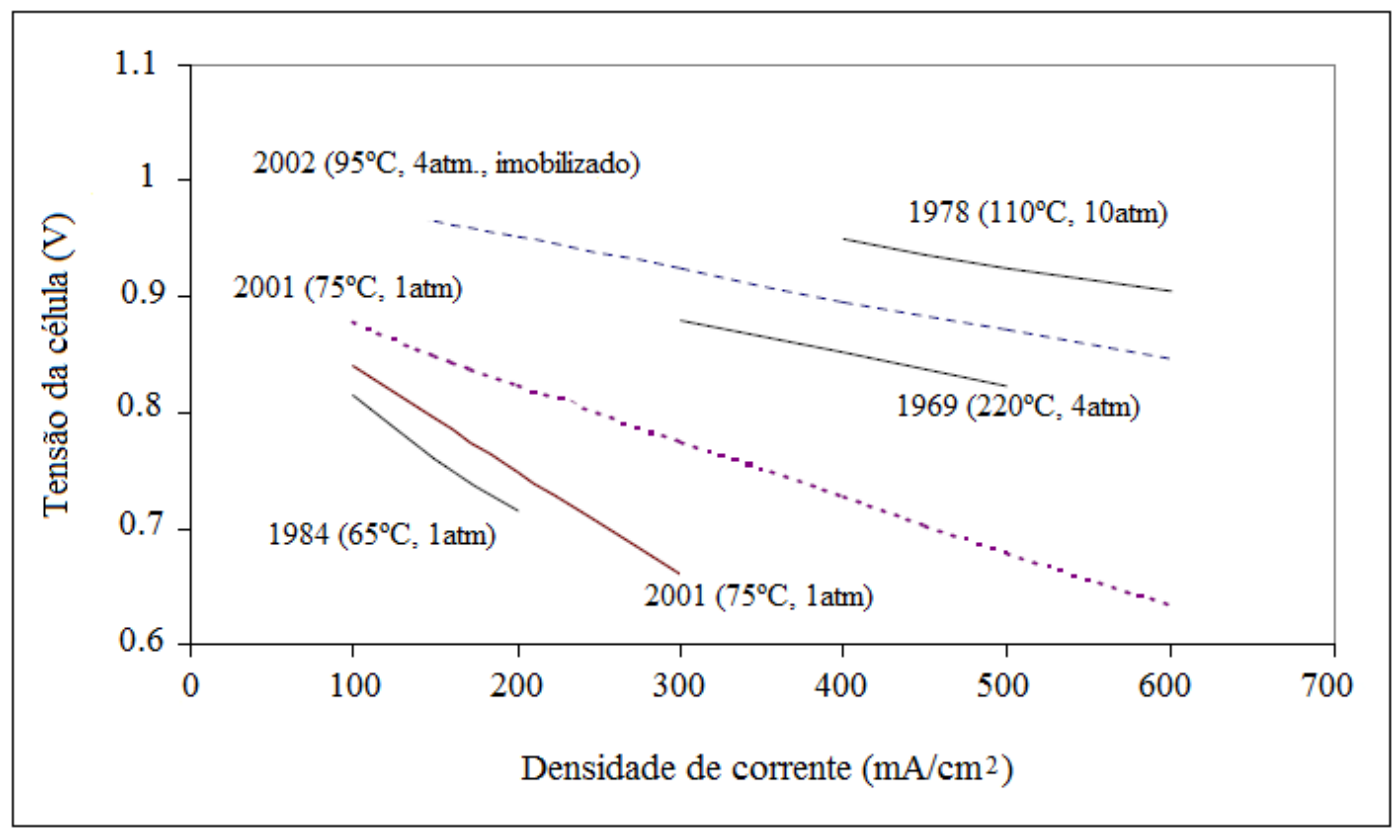

FIGURA 4 - Alterações Evolutivas no Desempenho de AFC's, adaptado de [12].

Com relação a comparação do desempenho da AFC com a célula PEM, não há dúvidas de que a tecnologia da PEMFC está produzindo densidades de potência com valores bem acima do desempenho relatado pelas células alcalinas ambiente. No entanto, os sistemas PEM são tipicamente pressurizados até pelo menos 30 Psi. Nos sistemas AFC pressurizados, foram relatadas, há muitos anos, densidades de potência semelhantes ou mesmo mais elevadas. Em vez de otimizar essas tecnologias de alta potência e conduzir os preços para baixo por meio da da fabricação de volume, a comunidade cientifica que estuda AFC evoluiu para sistemas de ar ambiente de menor potência. Portanto, os sistemas PEM e AFC são fundamentalmente diferentes. Os resultados publicados para sistemas PEM operados a ar ambiente sugerem desempenho que está na mesma ordem de magnitude que os sistemas alcalinos de ar ambiente [22]. Portanto, como justificativa, este estudo prioriza o uso de eletrólito alcalino, juntamente a adequação da membrana Náfion ${ }^{\circledR}$, a qual é utilizada convencionalmente nas células do tipo PEM.

\subsubsection{Célula a combustível de membrana trocadora de prótons (PEMFC)}

As células a combustível de membrana de eletrólito polimérico são capazes de gerar de forma eficiente altas densidades de potência, tornando a tecnologia potencialmente atrativa para aplicações móveis, portáteis e especialmente a possível 
aplicação deste tipo de protótipo como um motor para automóveis. A tecnologia PEMFC diferencia-se de outras tecnologias de células a combustível na medida em que uma membrana de polímero de fase sólida é utilizada como eletrólito e opera a temperaturas relativamente baixas, questões como selagem, montagem e manuseio são menos complexas do que na maioria das outras células a combustível. Um atrativo único à esse tipo de célula é o uso direto de metanol sem um processador de combustível; o que classifica o protótipo como célula a combustível de metanol direto (DMFC - Direct Methanol Fuel Cell). A DMFC é vista como a principal tecnologia candidata para a aplicação de células de combustível para câmeras, computadores e outras aplicações eletrônicas portáteis [2,12].

A primeira PEMFC foi desenvolvida primeiramente pela General Electric nos Estados Unidos em 1960 para o uso da NASA em seus primeiros veículos espaciais tripulados. As primeiras versões da PEMFC, usadas na NASA Gemini, tinham uma vida útil de cerca de $500 \mathrm{~h}$ que foi o suficiente para as missões mesmo com essa limitação no inicio. Os componentes que constituem um protótipo do tipo PEMFC incluem:

- a membrana de troca iônica;

- uma camada de suporte porosa eletricamente condutora;

- um eletrocatalisador (os eletrodos) na interface entre a camada de suporte e a membrana

- interconexões de células e placas de fluxo que entregam o combustível e o oxidante à locais reativos por meio de canais de fluxo e conectam eletricamente as células, conforme FIG.5 [12]. 


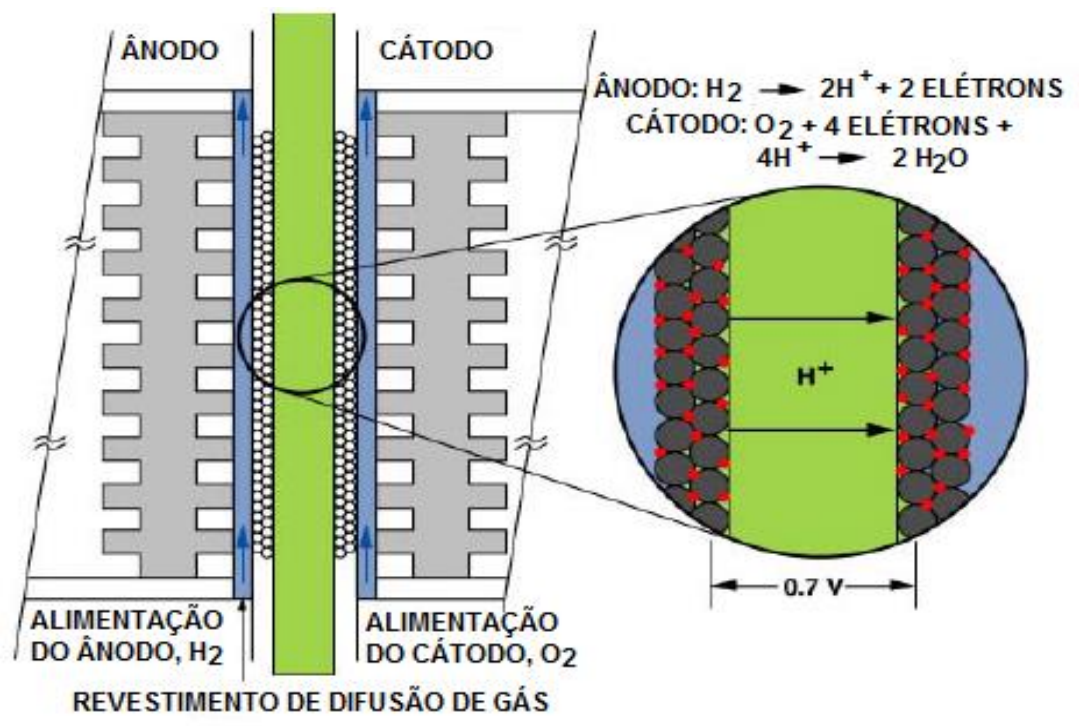

(A)

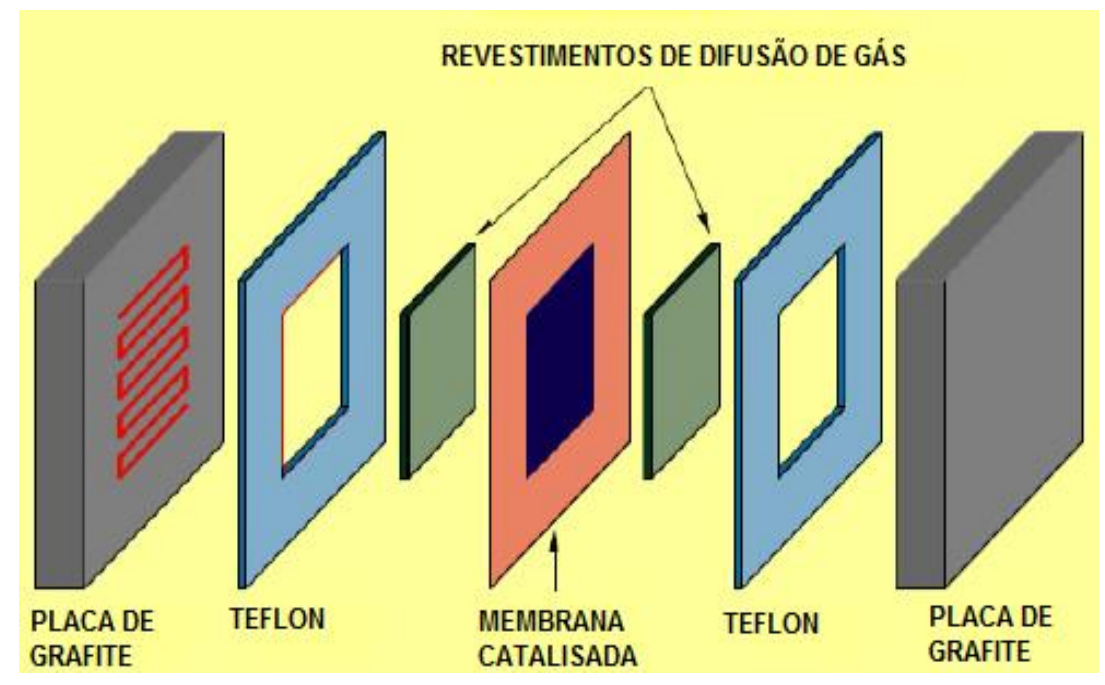

(B)

FIGURA 5 - (A) Esquema de PEMFC representativa (B) Estrutura de Célula Única do modelo PEMFC, adaptado de [12].

Tipicamente, os elétrodos são moldados como películas finas que são transferidas para a membrana ou aplicadas diretamente à mesma. Alternativamente, a camada de catalisador pode ser depositada sobre a camada de suporte, depois ligada à membrana [12].

O programa de desenvolvimento da empresa americana que produziu a primeira PEMFC continuou com estudos de melhorias e aperfeiçoamento do modelo, com 
a incorporação de uma membrana polimérica em 1967 chamada Náfion $^{\circledR}$, uma marca registrada da Dupont, que se tornou padrão para células desse tipo, como ainda é hoje [1].

A construção desse material eletrolítico parte da produção do polímero polietileno, o mais simples de entender, fabricado pelo homem. Este polímero basicamente é modificado substituindo o átomo de hidrogênio por flúor. Este processo é aplicado a diversos outros compostos e é chamado de perfluoração, produzindo assim o tetrafluoretileno. O polímero modificado é o politetrafluoroetileno ou PTFE também comercialmente vendido como Teflon. Este notável material tem sido muito importante no aperfeiçoamento e desenvolvimento de protótipos como as células à combustível. As fortes ligações entre os átomos de flúor e carbono tornam a membrana durável e resistente ao ataque químico. Outra propriedade importante é que ela é fortemente hidrofóbica e, portanto, é usada nos eletrodos para conduzir a água do produto para fora do eletrodo e, assim, evitar a inundação. É bem difundida e utilizada em células à combustível alcalinas, as de ácido fosfórico, bem como em PEMFC's [1].

No entanto, para ser utilizada como eletrólito, uma etapa adicional é necessária. O polímero básico de PTFE é "sulfonado", uma cadeia lateral é adicionada, terminando com ácido sulfônico, o $\mathrm{HSO}_{3}$. A sulfonação de moléculas complexas é uma técnica amplamente utilizada no processamento químico. Uma possível estrutura de cadeia lateral é mostrada na FIG. 6 a seguir, e os detalhes variam para diferentes tipos de Náfion ${ }^{\circledR}$, e para os diferentes fabricantes destas membranas.

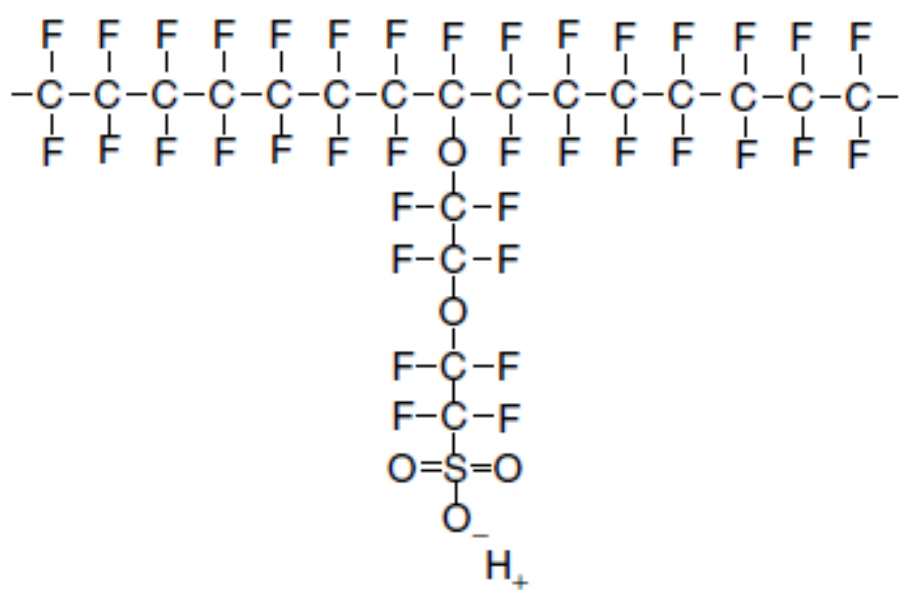

FIGURA 6 - Exemplo de estrutura de um flúor etileno sulfonado (também designado ácido perfluorossulfónico - PTFE) [1]. 
Os métodos de criação e adição das cadeias laterais são proprietários, no entanto, um método moderno foi discutido na literatura por Kiefer et al. [23] em que o ácido sulfônico $\mathrm{HSO}_{3}$ é ionicamente ligado, de modo que a extremidade da cadeia lateral seja um íon $\mathrm{SO}_{3}{ }^{-}$. O resultado da presença dos íons $\mathrm{SO}_{3}{ }^{-}$e $\mathrm{H}^{+}$é uma forte atração mútua decorrente da carga de cada molécula. As moléculas da cadeia lateral tendem a "aglomerar" dentro da estrutura geral do material. A propriedade chave decorrente do interesse à utilização do ácido sulfônico é que é altamente hidrofílico, ou seja, possui capacidade de forte interação com a molécula de água.

Na produção da membrana Náfion ${ }^{\circledR}$, isso significa que regiões hidrofílicas são criadas dentro de uma substância hidrofóbica, as regiões hidrofílicas ao redor dos aglomerados de cadeias laterais sulfonadas absorvem grandes quantidades de água, aumentando o peso seco do material até $50 \%$, já nas regiões hidratadas, os íons $\mathrm{H}^{+}$são relativamente fracos atraídos pelo grupo $\mathrm{SO}^{3}$ produzindo um ácido relativamente diluído capaz de se mover. O material resultante tem fases diferentes, regiões ácidas diluídas dentro de uma estrutura hidrofóbica forte, esta morfologia separada por micro-fases é ilustrada na FIG. 7 a seguir [1].

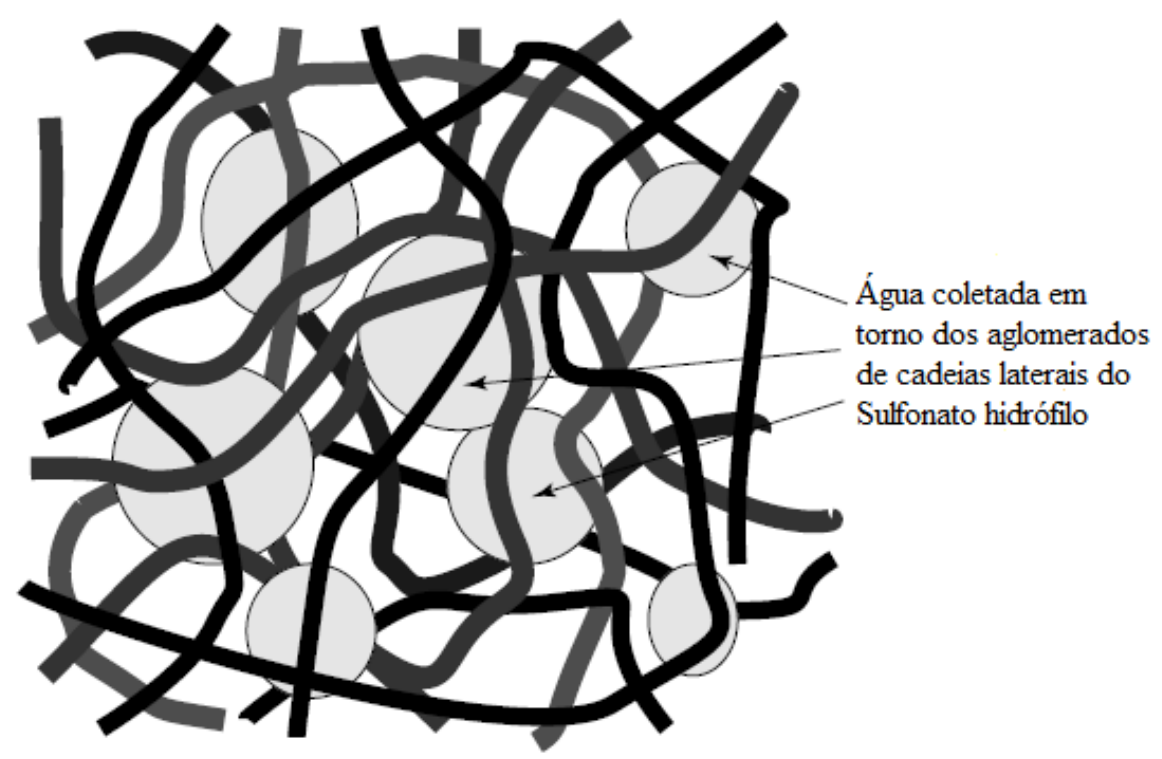

FIGURA 7 - A estrutura de um tipo de membrana Náfion ${ }^{\circledR}$. Moléculas de cadeia longa contendo regiões hidratadas em torno das cadeias laterais sulfonadas, adaptado de [1].

Embora as regiões hidratadas estejam um tanto separadas, é possível a mobilidade de íons $\mathrm{H}^{+}$por meio da estrutura de moléculas longas de suporte. No entanto, 
para que isso ocorra com maior facilidade as regiões hidratadas devem ser tão grandes quanto possível. Do ponto de vista do uso de células à combustível, as características de maior interesse de membranas Náfion $^{\circledR}$, se destacam a alta resistência, são fortes mecanicamente (e assim podem ser feitas em filmes muito finos, até $50 \mu \mathrm{m}$ ), são ácidas, podem absorver grandes quantidades de água e se estiverem bem hidratados, os íons $\mathrm{H}^{+}$ podem se mover livremente dentro do material além de serem bons condutores de prótons [1].

\subsubsection{Desafios para as PEMFC's}

Um dos principais estímulos ao aperfeiçoamento de protótipos do tipo PEMFC que utilizam $\mathrm{H}_{2}$ como combustível contaminados com $\mathrm{CO}$, consiste na redução de $\mathrm{CO}_{\text {ads }}$ na superfície da camada catalítica. Os elétrons do orbital $5 \sigma$ da Pt são doados a banda $5 \mathrm{~d}$ por retro-doação, preenchendo o orbital $2 \pi^{*}$ do metal, ocasionando uma forte interação do veneno catalítico $\mathrm{CO}$ na $\mathrm{Pt}$, maior que $\mathrm{H}_{2}$, fenômeno que ocasiona uma diminuição: i) dos sítios ativos disponíveis do metal para oxidação de hidrogênio, ii) da transferência protônica e iii) na geração de corrente [24].

$\mathrm{A}$ adsorção de $\mathrm{CO}$ sobre a superfície da $\mathrm{Pt}$ ocorre de 2 formas como representado na FIG. 8, a seguir.

(A)

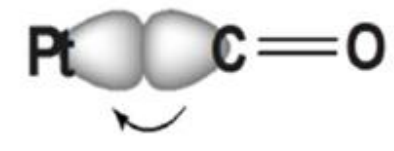

$5 \mathrm{p} \sigma$

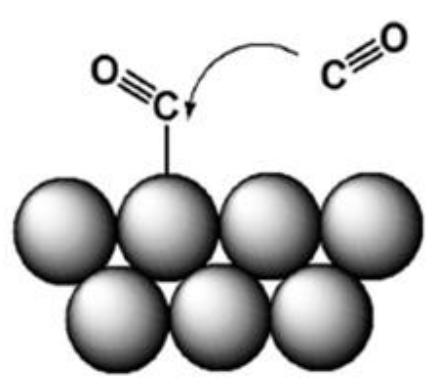

(B)

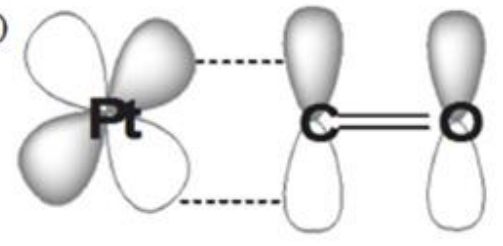

$5 \mathrm{~d} \pi \quad---2 \mathrm{p} \pi$

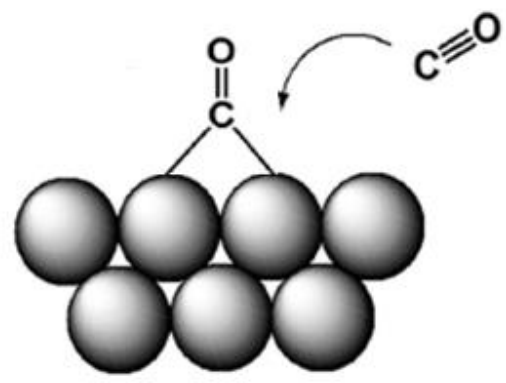

FIGURA 8 - Esquema dos tipos de ligação entre CO e Pt A) tipo linear B) tipo ponte [14].

A FIG. 8 A) é evidenciada a adsorção na Pt de forma linear, entre um sítio ativo e uma molécula de CO formando uma ligação entre o orbital 5po da Pt e o orbital $\sigma$ 
do $\mathrm{C}$ pertencente a CO. Na FIG 8 B) a adsorção tipo ponte é observada entre dois sítios ativos da Pt e uma molécula de $\mathrm{CO}$, na qual 2 ligações são formadas entre Pt e $\mathrm{CO}$ por intermédio dos orbitais $5 \mathrm{~d} \pi$ e $2 \mathrm{p} \pi$ do $\mathrm{C}$ do intermediário $\mathrm{CO}$. O tipo de ligação predominante depende do grau de recobrimento, sendo a adsorção linear predominante em altos graus [24].

Uma das principais propostas sugeridas com fins de diminuir o efeito do intermediário catalítico $\mathrm{CO}$ adsorvido na Pt é a síntese de eletrocatalisadores binários e ternários suportados em carbono, onde o segundo e o terceiro metal corresponde a metais como Ru e In conforme proposto neste trabalho. A maior tolerância dos catalisadores desse tipo se dá ao efeito eletrônico e ao mecanismo bifuncional (assunto melhor discutido no cap. 2.4.1) ou efeito de ambos.

\subsection{ELETRO-OXIDAÇÃO DE METANOL E CÉLULAS DMFC}

A oxidação eletrocatalítica do metanol $\left(\mathrm{CH}_{3} \mathrm{OH}\right)$ tem sido uma reação atraente aos pesquisadores, uma vez que esse combustível se mostrou uma fonte de energia alternativa relativamente limpa. Sistemas eletroquímicos que utilizam metanol como combustível possuem muitas vantagens, tais como: as condições de armazenamento que são mais fáceis, a produção de alta densidade de energia $\left(6,1 \mathrm{kWh} \mathrm{kg}^{-1}\right)$, a baixa produção de poluentes ambientais, além de poderem ser aplicados a dispositivos portáteis e converterem energia química em elétrica diretamente. Isto é, conhecida a reação anódica lenta, grandes esforços por parte de pesquisas em eletrocatálise são atualmente conduzidas ao desenvolvimento de eletrocatalisadores economicamente viáveis [25,26].

Embora, a utilização do metanol apresente diversas vantagens, a reação possui limitações que implica em perda por sobrepotencial, além de possuir um complexo mecanismo reacional. A partir de estudos cinéticos, um mecanismo de caminho duplo sobre Pt a potenciais suficientemente elevados foram evidenciados, mostrando rotas tanto "direta" (sem $\left.\mathrm{CO}_{\mathrm{ads}}\right)$ quanto "indireta" $\left(\mathrm{CO}_{\mathrm{ads}}\right)$ para a reação como mostra o esquema simplificado na FIG. 9 [6]. A rota direta procede por meio da formação de intermediários reativos, a saber, formaldeído e ácido fórmico. Ambos possivelmente são precursores na formação do intermediário formiato $\left(\mathrm{HCOO}_{\mathrm{ads}}\right)$ na produção de $\mathrm{CO}_{2}[27,28]$ e também na produção de $\mathrm{CO}_{\mathrm{ads}}$ [29]. Já, a rota indireta, ocorre pela formação de monóxido de carbono 
adsorvido $\left(\mathrm{CO}_{\mathrm{ads}}\right)$, o qual reage com espécies oxigenadas em altos potenciais via mecanismo de Langmuir-Hinshelwood, conforme abordado na Seção 2.4.1.

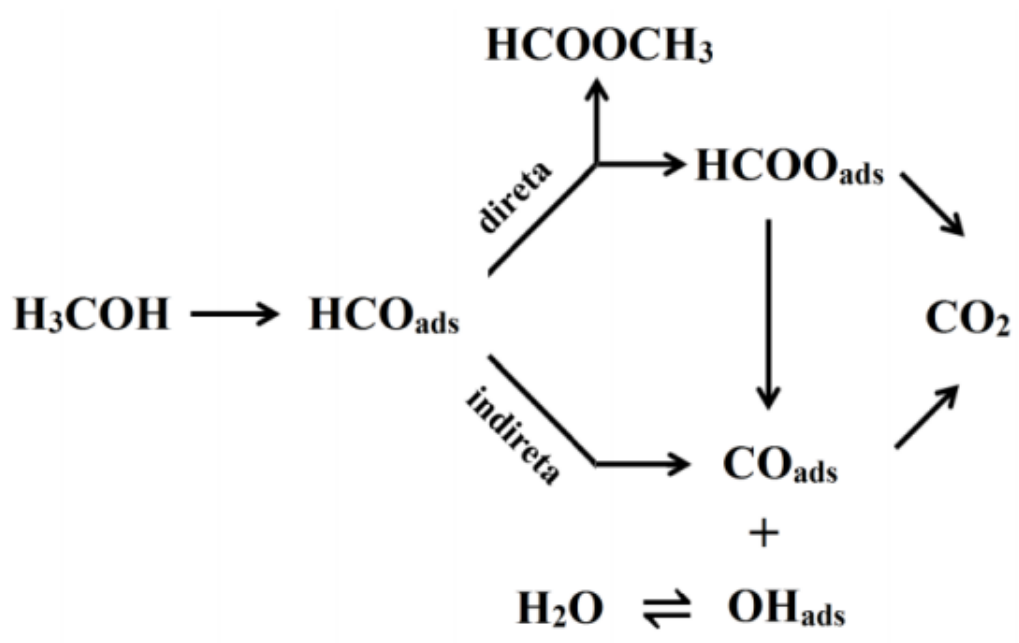

FIGURA 9 - Esquema simplificado para a eletro-oxidação de metanol e formação dos seus respectivos intermediários [6].

Os estudos de Korzeniewski et al. [30-32] realizados em diferentes eletrólitos sugeriram que o formaldeído é o produto secundário predominante por via direta e requer tamanhos de conjuntos significativamente menores do que para a ocorrência por via indireta. Os experimentos de Osawa et al. [33-35] por outro lado, usaram espectroscopia de infravermelho com realce de superfície para sugerir que a via dupla prossegue por meio de formação de intermediários de formiato na superfície, que se formam em elétrodos de platina policristalinos a potenciais superiores a $0,7 \mathrm{~V}$ de RHE e subsequentemente oxidam para formar ácido fórmico em vez de formaldeído. Já Koper et al. [36,37] mostraram que o formaldeído e o ácido fórmico poderiam reagir um ao outro.

Portanto, o entendimento da eletro-oxidação do metanol é essencial para se otimizar o uso desse combustível em uma célula do tipo DMFC. A DMFC possui a mesma construção de uma PEMFC, porém, o combustível que sofre uma oxidação anódica direta é o metanol. O combustível pode ser alimentado de forma líquida ou vaporizada, diluído com $\mathrm{H}_{2} \mathrm{O}$ e $\mathrm{N}_{2}$ [17]. A reação global que ocorre em uma DMFC é representada pela reação a seguir: 
A energia livre de Gibbs dessa reação equivale a $-698,2 \mathrm{~kJ} \mathrm{~mol}^{-1}$, em que seis elétrons são transferidos por molécula de metanol [1]. Embora esta reação tenha potencial termodinâmico comparado a reação de oxidação do hidrogênio, a comercialização das células do tipo DMFC é impedida pela lenta cinética da reação, particularmente em baixas temperaturas. O desempenho em célula é prejudicado por diversos motivos, dentre eles: baixa atividade dos eletrocatalisadores atuais, envenenamento no anodo por intermediários fortemente adsorvidos como o CO formados na oxidação do metanol e alta permeabilidade através da membrana que despolariza o cátodo da célula, onde este fenômeno é conhecido por “crossover". Em comparação com as PEMFC's (quando operam com $\mathrm{H}_{2}$ puro), as DMFC's operam com um potencial de 1,18V contra 1,23V das células tipo PEM [38].

\subsection{ELETROCATALISADORES}

A ocorrência da eletrocatálise pode ser definida como a aceleração de uma reação de eletrodo por uma substância que não é consumida na reação global, catalíticamente ativa que é, geralmente, a superfície do eletrodo, definida como eletrocatalisador, responsável pela aceleração de uma reação com, no mínimo, uma etapa eletroquímica. Logo, o eletrocatalisador pode ser classificado como catalisador heterogêneo devido ao fato de que, no mínimo, uma etapa da reação eletroquímica ocorre na interface eletrólito/eletrodo. Em determinado acordo de eletrólito/eletrodo e diferença de potencial, especificamente as propriedades da superfície do eletrodo afetam as taxas da reação global [39].

Os sistemas de catalisadores heterogêneos (acelera somente partes da etapa da reação sem transferência de carga) é representado pela platina e outros sistemas baseados em platina juntamente com outros metais de transição da tabela periódica, formando sistemas catalíticos binários ou ternários. Eles catalisam a reação eletroquímica por aceleração de dissociação, por exemplo, do gás hidrogênio em átomos de hidrogênio que é então seguida por ionização [39].

As reações que ocorrem em células a combustível são reações de adsorção de espécies eletroativas na superfície dos eletrocatalisadores produzidos, onde sua atividade 
catalítica é fortemente dependente da distribuição de tamanho e da uniformidade da distribuição das nanopartículas sobre o suporte, bem como, da morfologia, da estrutura e da composição superficial das mesmas [40]. Tais dependências justificam os recentes esforços no desenvolvimento de novos métodos de preparação de nanopartículas suportadas em carbono.

\subsubsection{Mecanismo bifuncional e efeito eletrônico}

Em tópicos anteriores, foi mencionado o envenenamento do ânodo por intermediários como o $\mathrm{CO}$ fortemente adsorvidos nos sítios catalíticos [24]. A maneira pela qual se dá a remoção desses intermediários é por meio de dois efeitos denominados mecanismo bifuncional e efeito eletrônico.

No mecanismo bifuncional, propõe-se que a espécie reagente $\left(\mathrm{H}_{2}, \mathrm{CH}_{3} \mathrm{OH}\right.$, $\mathrm{CH}_{3} \mathrm{CH}_{2} \mathrm{OH}$ ) e o contaminante se adsorvem preferencialmente nos átomos de $\mathrm{Pt}$, enquanto que o outro metal, menos nobre e mais oxidável, produza espécies oxigenadas ou óxidos hidratados que atuam diretamente na oxidação do intermediário por meio dos modelos do tipo Langmuir-Hinshelwood e Eley-Rideal [41-43]. Langmuir-Hinshelwood postula que a reação na fase líquida ou gasosa catalisada por um sólido ocorre entre espécies adsorvidas no sítio ativo da superfície catalítica. Considerando-se assim que o catalisador aumenta a velocidade da reação por meio da sua habilidade de interagir com o reagente de tal maneira que a energia de ativação é sensivelmente reduzida em relação a mesma reação sem catalisador [44]. Já Eley-Rideal considera a reação entre duas moléculas, uma adsorvida e

outra não. É um modelo simplificado derivado de Langmuir-Hinshelwood e é geralmente utilizado para reações em fase gasosa [43].

Lee e colaboradores estudaram o efeito bifuncional para remoção de $\mathrm{CO}$ como veneno catalítico por meio de um sistema modelo composto de RuOxHy misturado com nanocatalisadores de Pt de ultima geração. No estudo, a ausência do efeito eletrônico foi confirmada por várias análises físico-químicas. Por medições eletroquímicas e também por análises de célula única foi verificado o aumento da remoção de $\mathrm{CO}$ e modificações das propriedades de oxidação por oxofilicidade. Além disso, os mecanismos de reação de Langmuir-Hinshelwood e Eley-Rideal foram observados para a remoção de CO no caso de catalisadores mistos, assim como a combinação de ambos que permitiu uma gestão eficaz do veneno catalítico [45]. 
O mecanismo de Lagmuir-Hinshelwood, no caso, dependeu fortemente da cobertura de $\mathrm{OH}_{\mathrm{ad}}$ e é dominante para a remoção de $\mathrm{CO}$ na faixa de alto potencial. Já a oxidação de $\mathrm{CO}$ pela reação direta entre $\mathrm{CO}_{\mathrm{ad}}$ e espécies de oxigênio que não são adsorvidas na superfície de $\mathrm{Pt}$, ocorre no caso de alta cobertura de $\mathrm{CO}$, segundo o mecanismo de Eley-Rideal [45]. A vantagem do mecanismo bifuncional para o objetivo deste estudo, é que a nucleação de espécies oxigenadas no segundo metal ocorre em potenciais eletródicos menos positivos em relação à platina pura, ou seja, o papel do segundo metal se baseia na relativa facilidade que apresenta de formar óxidos hidratados em sobrepotenciais mais baixos que a platina. Desta maneira, essas espécies desempenham o papel de agentes oxidantes, convertendo o $\mathrm{CO}$ quimissorvido na platina a $\mathrm{CO}_{2}$, que rapidamente se dessorve da superfície do catalisador [21].

O efeito eletrônico, postula que a presença de um segundo metal causa variações no centro da banda d da platina, sendo que a posição do centro da banda d é uma medida da energia de adsorção de um adsorvato. Estudos teóricos realizados por Hammer et al. consideraram que um parâmetro importante para medir a força de ligação é a posição do centro da banda d para os metais e a distância aos orbitais do adsorvato (por exemplo, CO). Quanto maior a energia do centro da banda d, maior será a interação Pt-CO. Números em eletrón-Volt $(\mathrm{eV})$ positivos indicam uma mudança da banda d para mais perto do nível de Fermi (nível eletrônico mais alto ocupado), valores negativos indicam um deslocamento da banda d mais distante do nível de Fermi [46].

$\mathrm{O}$ aumento da tolerância ao $\mathrm{CO}$ para $\mathrm{PtRu}$ por exemplo, em relação à Pt pura pode ser atribuído a uma menor energia de adsorção de $\mathrm{CO}$ sobre $\mathrm{Pt}$, em razão desta mudança do centro de banda $\mathrm{d}$. $\mathrm{O}$ efeito da adição de um segundo metal à platina foi analisado por espectroscopia de absorção de raio-x (XAS) in situ, e observado que os átomos de platina na liga apresentam alterações tanto no ordenamento atômico (distância da ligação Pt-Pt, número de coordenação, etc.) como nos níveis eletrônicos (ocupação da banda 5-d) quando comparado ao sistema que utiliza Pt pura nas mesmas condições, o que caracteriza a presença de efeito eletrônico [47,48].

\subsubsection{Método de redução via borohidreto de sódio}

Muitos estudos têm demonstrado que a atividade dos eletrocatalisadores é bastante influenciada por diversos fatores relacionados ao método de preparação. Um dos métodos mais aplicados é o da impregnação, que redutores como o etilenoglicol, ácido 
fórmico e $\mathrm{NaBH}_{4}$ são utilizados [49]. O redutor escolhido a ser utilizado na síntese dos eletrocatalisadores para aplicação em células a combustível deste estudo foi o borohidreto de sódio. $\mathrm{O}$ borohidreto de sódio $\left(\mathrm{NaBH}_{4}\right)$ é em sua maior parte encontrado, na forma de um sólido branco, inodoro, com boa solubilidade em metanol (13 g/100 mL), etanol (3,16 g/100 mL) e água (54 g/100 mL). Em metanol e etanol, apesar de solúvel, decompõe-se em boratos. Em água é estável em pH 14, decompondo-se rapidamente em soluções neutras e ácidas. Trata-se de um agente redutor relativamente forte, bastante utilizado na produção de compostos orgânicos e inorgânicos. O método de redução via borohidreto é de simples execução e, relativamente, reprodutível, além da sua eficácia comprovada na produção de nanopartículas [50]. 


\section{OBJETIVOS}

O objetivo deste trabalho consiste na preparação dos sistemas eletrocatalíticos binários e ternários $\mathrm{Pt} / \mathrm{C}, \mathrm{In} / \mathrm{C}, \mathrm{PtIn} / \mathrm{C}, \mathrm{PtRu} / \mathrm{C}$ e $\mathrm{PtRuIn} / \mathrm{C}$ em diferentes composições atômicas pelo método de redução via borohidreto de sódio.

Executar a caracterização físico-química dos materiais preparados e testar os eletrocatalisadores sintetizados frente a eletro-oxidação de metanol pelas técnicas de voltametria cíclica e cronoamperometria utilizando a técnica da camada fina porosa.

Estudar a oxidação eletroquímica do metanol em meio alcalino utilizando os sistemas catalíticos produzidos como eletrodo anódico em aplicação à células a combustível de metanol direto.

Analisar a influência dos elementos Índio e Rutênio na atividade dos sistemas binários PtIn/C e PtRu/C, bem como no sistema ternário PtRuIn/C, e suas estabilidades nas reações de eletrocatálise em meio alcalino. 


\section{MATERIAIS E MÉTODOS}

\subsection{PREPARAÇÃO E CARACTERIZAÇÃO DOS ELETROCATALISADORES}

Para a preparação dos sistemas catalíticos binários e ternários e suas diferentes composições atômicas, utilizou-se ácido Cloroplatinico Hexahidratado $\left(\mathrm{H}_{2} \mathrm{PtCl}_{6} \cdot 6 \mathrm{H}_{2} \mathrm{O}\right.$ Aldrich), Cloreto de Rutênio Hidratado $\left(\mathrm{RuCl}_{3} \cdot x \mathrm{H}_{2} \mathrm{O}-\right.$ Aldrich) e Cloreto de Índio $\left(\mathrm{InCl}_{3} \cdot x \mathrm{H}_{2} \mathrm{O}-\right.$ Aldrich) como fonte de metais, com carga metálica nominal de $20 \%$, álcool 2-propanol (Merck) como solvente, Borohidreto de Sódio $\left(\mathrm{NaBH}_{4}-\right.$ Aldrich) como agente redutor, Hidróxido de Potássio (KOH - Merck) como agente estabilizante para evitar a degradação do Borohidreto de Sódio e negro de fumo Vulcan® XC72 (Cabot) como suporte de carbono, em condições ambiente (temperatura, pressão e atmosfera).

Os precursores metálicos e o suporte de carbono foram adicionados, sob agitação, em uma solução 2-propanol/água com razão volumétrica igual a 50/50 (v/v). Após este processo adicionou-se uma solução contendo $10 \mathrm{~mL}$ de solução $0,01 \mathrm{~mol} \mathrm{~L}^{-1} \mathrm{de}$ $\mathrm{KOH}$ e $\mathrm{NaBH}_{4}$ (razão molar $\mathrm{NaBH}_{4}$ :metais igual a 5:1). A solução resultante foi submetida a agitação por 30 minutos. O eletrocatalisador obtido foi filtrado a vácuo, lavado com água e seco a $70^{\circ} \mathrm{C}$ por 2 horas.

A metodologia estudada a partir do método de redução via Borohidreto, foi por adição rápida [50], onde a solução de borohidreto é adicionada em uma única etapa.

\subsection{CARACTERIZAÇÃO FÍSICO-QUÍMICA DOS ELETROCATALISADORES}

Os eletrocatalisadores preparados foram caracterizados por Espectroscopia de Energia Dispersiva de Raios-X (EDX), Difração de Raios-X (DRX) e Microscopia Eletrônica de Transmissão (MET).

\subsection{ESPECTROSCOPIA DE ENERGIA DISPERSIVA DE RAIOS-X}

A Espectroscopia de Energia Dispersiva de Raios-X é uma técnica analítica semi-quantitativa integrada ao microscópio eletrônico de varredura para identificar ou caracterizar a composição química de uma amostra. 
Para os estudos com a técnica de EDX as amostras dos eletrocatalisadores foram preparadas pela prensagem de uma fina camada de pó em uma tinta colante sobre um porta-amostra de bronze e introduzido ao Microscópio Eletrônico de Varredura (MEV). As análises foram realizadas no Microscópio Eletrônico de Varredura Philips, modelo XL30 com feixe de elétrons de $20 \mathrm{keV}$ equipado com microanalisador EDAX modelo DX4. Foram coletados dados em três pontos distintos e aleatórios da amostra e o resultado final, corresponde a uma média destes pontos.

Os dados obtidos pelas análises de Espectroscopia de Energia Dispersiva de Raios-X permitiram a obtenção de uma análise da composição química do catalisador e os espectros em forma de pico indicam os níveis de energia do salto [51].

\subsection{DIFRAÇÃO DE RAIOS-X}

As análises dos difratogramas de Raios-X permitem a obtenção de informações quanto à estrutura cristalina dos eletrocatalisadores bem como a estimativa do tamanho médio de cristalito, da fase presente no eletrocatalisador, determinados por intermédio da equação de Scherrer (Equação 2) [52].

As medidas de Difração de Raios-X foram obtidas em um difratômetro de Raios-X da Rigaku modelo Miniflex II com fonte de radiação de CuK $\alpha$ ( $\lambda=1,54056 \AA$ ), varredura em $2 \theta$ de $20^{\circ}$ a $90^{\circ}$ com velocidade de varredura de $2^{\circ} \mathrm{min}^{-1}$. Para estes experimentos uma pequena quantidade do eletrocatalisador foi compactada em um suporte de vidro, onde este foi posteriormente colocado na câmara do difratômetro de Raios-X, para obtenção de resultados.

Para se estimar o valor médio do diâmetro dos cristalitos do eletrocatalisador foi usada a equação de Scherrer (Equação 2) utilizando o pico de reflexão correspondente ao plano (220) da estrutura CFC da platina e suas ligas.

$$
d=\frac{K \cdot \lambda}{\beta \cdot \cos \theta}
$$


Onde $d$ é o diâmetro médio das partículas em Angstroms, $K$ é uma constante que depende da forma dos cristalitos, neste trabalho foi utilizado o valor de $K=0,9$ admitindo-se cristalitos esféricos, $\lambda$ é o comprimento de onda da radiação usada, no caso do $\mathrm{CuK} \alpha, \lambda=1,54056 \AA$ A. Segundo a literatura o valor de $\beta$ pode ser dado, na prática, apenas como a largura da meia altura, em radianos, do pico referente ao plano (220) da amostra medida e $\theta$ é o ângulo de Bragg em graus para o ponto de altura máxima do pico analisado (220).

Os parâmetros de rede para os eletrocatalisadores foram calculados utilizando os valores do comprimento de onda da radiação usada $(\lambda)$ e do ângulo de $\operatorname{Bragg}(\theta)$, em graus, para o ponto de altura máxima do pico analisado (220), a partir da Equação 3 [52].

$$
\alpha_{c f c}=\frac{\sqrt{2} \cdot \lambda}{\operatorname{sen} \theta}
$$

\subsection{MICROSCOPIA ELETRÔNICA DE TRANSMISSÃO}

Para os estudos de microscopia eletrônica de transmissão foi utilizado um Microscópio Eletrônico de Transmissão JEOL modelo JEM-2100 (200kV). Para a análise em microscopia eletrônica de transmissão foi preparada uma suspensão de cada catalisador em 2-propanol, onde esta foi homogeneizada em um sistema de ultrasom. Posteriormente, uma alíquota da amostra foi depositada sobre uma grade de cobre $(0,3 \mathrm{~cm}$ de diâmetro) com um filme de carbono. Em média, foram tomadas 8 micrografias para cada amostra, de forma que a coleta de dados permitisse a construção de histogramas que representassem a distribuição do tamanho de partículas. Foram medidas digitalmente cerca de 120 partículas em cada amostra (utilizando o programa: Image Pro Plus Software) para construção dos histogramas e o cálculo do tamanho médio de partícula. Através da microscopia eletrônica de transmissão foi possível a determinação do grau de dispersão das nanopartículas no suporte de carbono, bem como o tamanho médio das nanopartículas e, como mencionado, a construção de histogramas representando a distribuição de tamanhos. 


\subsection{CARACTERIZAÇÃO ELETROQUÍMICA DOS ELETROCATALISADORES}

As técnicas eletroquímicas utilizadas foram a voltametria cíclica e a cronoamperometria, cuja finalidade para todas as composições, foi verificar a atividade do material em função do potencial aplicado, a estabilidade e a atividade do eletrocatalisador ao longo do tempo de operação num determinado potencial, além de comparar as diferentes proporções atômicas dos metais.

Na FIG. 10 observa-se o voltamograma cíclico típico da Platina policristalina em eletrólito alcalino, onde se verifica a existência de picos definidos, tanto na varredura anódica como na catódica (região de potenciais entre 0,10 e $0,40 \mathrm{~V}$ ), provenientes do processo de adsorção/dessorção de Hidrogênio.

Posteriormente, na faixa de potencial de 0,40 a $0,75 \mathrm{~V}$ se encontra a região de dupla camada elétrica, e logo adiante se observa a formação de dois picos anódicos, no intervalo de potenciais entre 0,75 e 1,00 V, correspondente a processos de oxidação na superfície da Pt, com consequente formação de óxidos. Na varredura catódica, o pico presente entre 0,50 e 0,90 V está associado com a redução de óxido de Pt [53].

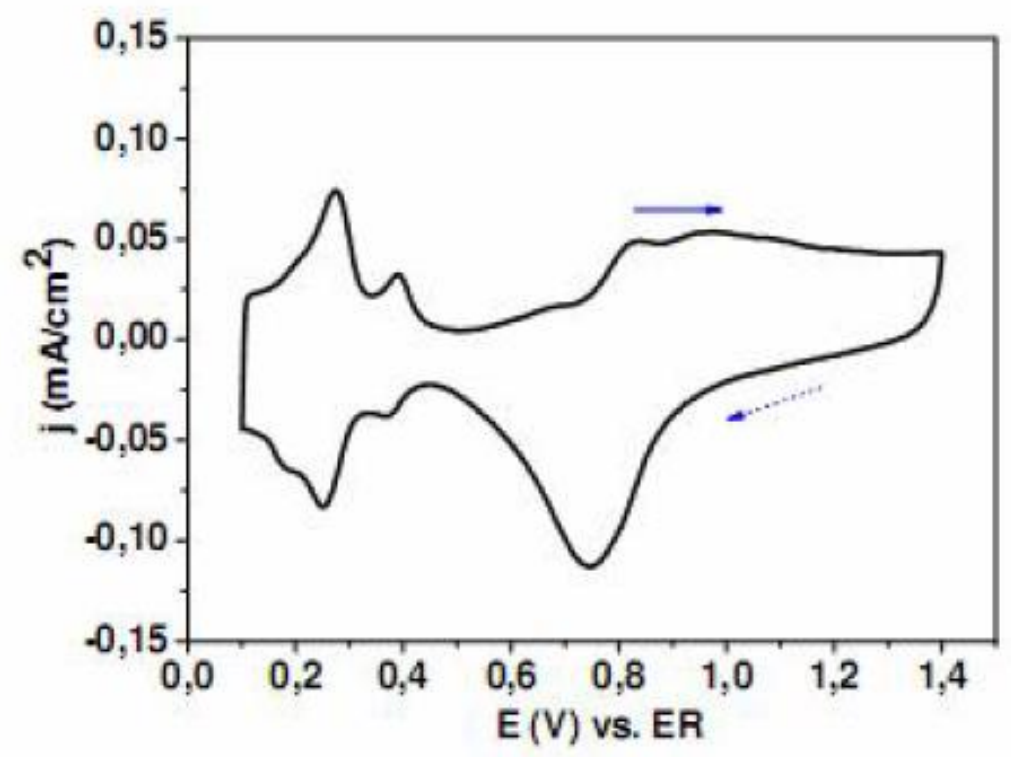

FIGURA 10 - Voltamograma característico do eletrocatalisador $\mathrm{Pt} / \mathrm{C}$, na presença de 1,0 mol L-1 de $\mathrm{NaOH}$; varredura anódica $(\longrightarrow)$, varredura catódica $($ ( $\cdots \cdots \cdots \cdot \ldots$ 
Os eletrocatalisadores obtidos foram eletroquimicamente caracterizados utilizando a técnica da camada fina porosa [54].

A técnica da camada fina porosa consiste na preparação de uma pasta através da mistura de $20 \mathrm{mg}$ do eletrocatalisador, $50 \mathrm{~mL}$ de água deionizada e 3 gotas de uma dispersão $6 \%(\mathrm{v} / \mathrm{v})$ de Teflon. A mistura é submetida a um sistema de ultra-som por 10 minutos. Posteriormente, a mistura é filtrada e o sólido ainda úmido é transferido para a cavidade $\left(0,3 \mathrm{~mm}\right.$ de profundidade e $0,36 \mathrm{~cm}^{2}$ de área) do eletrodo de trabalho, sendo então compactado de forma que a superfície fique homogênea. A FIG. 11 representa o modelo do eletrodo de trabalho utilizado neste estudo.

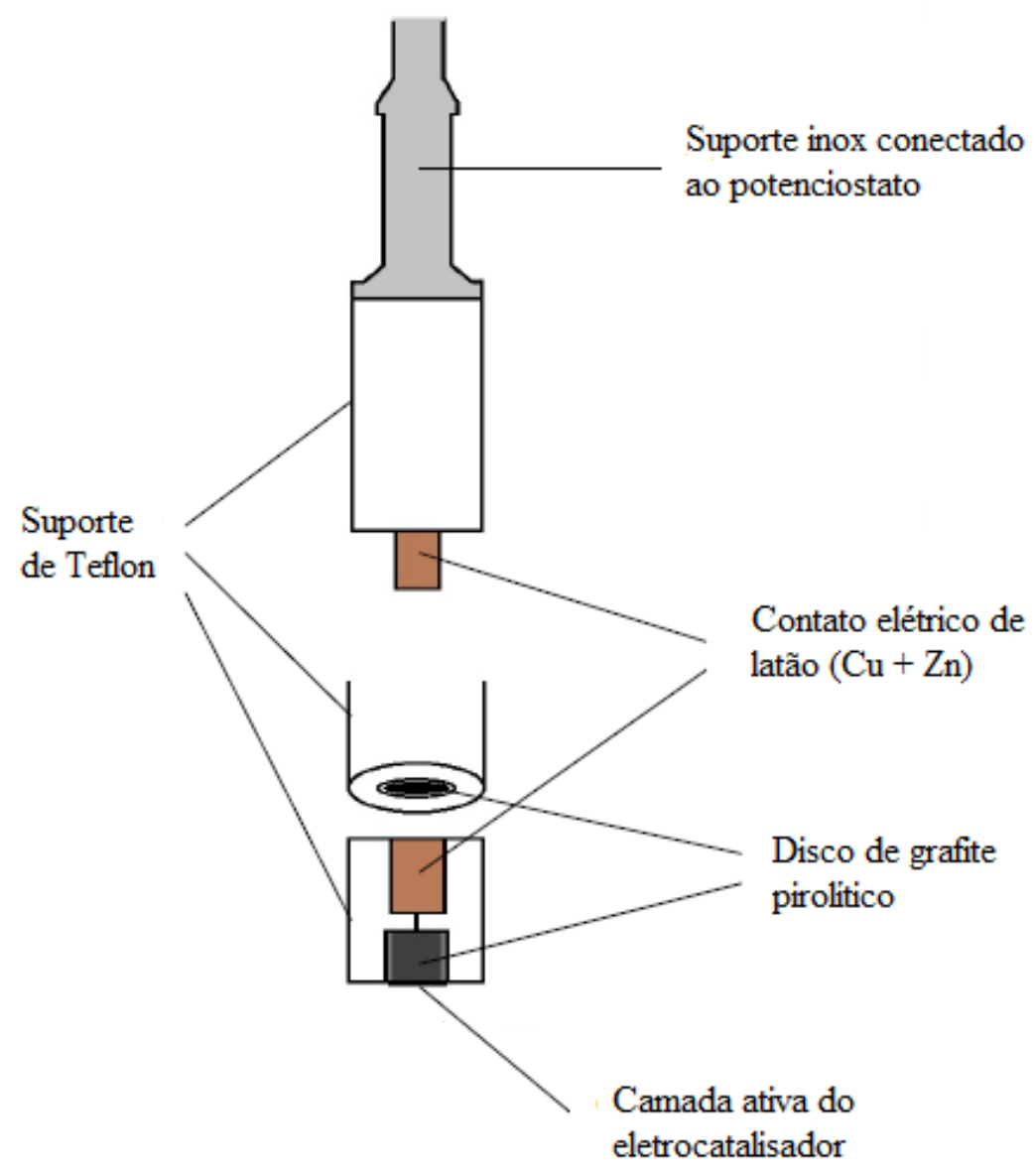

FIGURA 11 - Modelo de um eletrodo de trabalho de grafite pirolítico acoplado a um suporte de teflon utilizado para testes eletroquímicos [21].

Os experimentos de voltametria cíclica e cronoamperometria ocorreram na presença de um eletrólito suporte de $1,0 \mathrm{~mol} \mathrm{~L}^{-1}$ de $\mathrm{KOH}$ e foram realizados usando uma 
célula de três eletrodos [54]: o eletrocatalisador como eletrodo de trabalho, um eletrodo de $\mathrm{Ag} / \mathrm{AgCl}\left(3 \mathrm{~mol} \mathrm{~L}^{-1} \mathrm{KCl}\right)$ foi utilizado como eletrodo de referência e uma placa de platina como contra-eletrodo. Esses experimentos foram executados em um potenciostato/galvanostato AutoLab PGSTAT 30 acoplado a um computador usando o software Microquímica para interface. Os estudos em meio alcalino foram realizados em soluções em concentração de 1,0 mol.L ${ }^{-1}$ de metanol em um potencial de $-0,85 \mathrm{~V}$ a $0,2 \mathrm{~V}$, considerando uma velocidade de varredura de $10 \mathrm{mV} . \mathrm{s}^{-1}$. Durante todos os experimentos a solução foi saturada com $\mathrm{N}_{2}$, no potencial $-0,4 \mathrm{~V}$.

Foram feitas três coletas de dados. A primeira foi feita, por meio da voltametria cíclica usando somente a presença de hidróxido de potássio; a segunda coleta de dados também foi obtida por voltametria cíclica utilizando a solução de hidróxido de potássio com 1,0 mol. $\mathrm{L}^{-1}$ de metanol; e a última coleta obtida por meio da cronoamperometria, utilizando a solução da segunda medida.

Após as medidas, o eletrocatalisador foi retirado do eletrodo de trabalho e levado ao forno por 30 minutos para secagem. Ao retira-lo a massa foi medida. A quantidade de platina foi calculada multiplicando o valor da massa obtida pela porcentagem de platina utilizada no eletrocatalisador.

Os resultados foram analisados através de gráficos de corrente elétrica em função da diferença de potencial para a voltametria cíclica e corrente elétrica em função do tempo para a cronoamperometria.

\subsection{PRODUÇÃO DO CONJUNTO MEMBRANA-ELETRODO (MEA)}

As membranas Nafion ${ }^{\circledR}$, usadas como eletrólitos, foram lavadas e tratadas com $\mathrm{H}_{2} \mathrm{O}_{2}(3 \%)$, para eliminar impurezas orgânicas que eventualmente estivessem contidas na mesma. Posteriormente, foram lavadas para eliminar os traços de $\mathrm{H}_{2} \mathrm{O}_{2}$ e colocadas em $\mathrm{H}_{2} \mathrm{SO}_{4}\left(1,0\right.$ mol L $\left.{ }^{-1}\right)$ para eliminação das impurezas metálicas. Para eliminar os traços de $\mathrm{H}_{2} \mathrm{SO}_{4}$ as membranas foram lavadas por três vezes. Em todos os banhos realizados foi utilizada água ultrapura. Os tratamentos químicos foram realizados na temperatura de $80^{\circ} \mathrm{C}$ pelo período de $1 \mathrm{~h}$, sendo o último tratamento a submersão do polímero por $24 \mathrm{~h}$ em solução $6 \mathrm{~mol} \mathrm{~L}^{-1}$ de $\mathrm{KOH}$. 
Para a confecção de cada MEA utilizou-se uma membrana Nafion ${ }^{\circledR} 117$ da DuPont $^{\mathrm{TM}}$, nas dimensões $7 \mathrm{~cm} \mathrm{x} 7 \mathrm{~cm}$, aproximadamente; dois tecidos de carbono (ECCC1-060T), com $5 \mathrm{~cm}^{2}$ de área geométrica, tratados com politetrafluoretileno (PTFE) $35 \%$, fornecido pela ElectroChem Inc; eletrocatalisador comercial Pt/C E-TEK (20\% de Pt em massa, lote: C0740621), empregado no catodo; e o eletrocatalisador preparado pelo método de redução por Borohidreto de Sódio, usado no ânodo. Utilizou-se uma carga metálica de $1 \mathrm{mg}_{\mathrm{Pt}} \mathrm{cm}^{-2}$ para o catodo e para o ânodo. As camadas catalíticas preparadas foram aplicadas manualmente sobre o tecido de carbono pela técnica de pintura por pincel até a total transferência da carga catalítica. Após a pintura dos eletrodos estes foram colocados na estufa a $70{ }^{\circ} \mathrm{C}$ por 2 horas para secagem. Em seguida para a formação do MEA os dois eletrodos preparados foram prensados junto a membrana de Náfion ${ }^{\circledR}$, a 125 ${ }^{\circ} \mathrm{C}$ por 20 minutos a uma pressão de 5 toneladas [49].

As medidas de polarização foram realizadas em uma célula unitária ElectroChem com placas de grafite para distribuição do combustível do tipo serpentina, com o oxigênio umidificado externamente usando uma garrafa umidificadora de temperatura controlada e aquecida a temperatura de $85{ }^{\circ} \mathrm{C}$. A temperatura da célula também foi ajustada para $80{ }^{\circ} \mathrm{C}$, sendo que o ânodo da célula foi alimentado com uma solução de metanol e KOH na concentração de $2 \mathrm{~mol} \mathrm{~L}^{-1}$ com um fluxo de aproximadamente $1 \mathrm{~mL} \min ^{-1}$. Os testes na célula unitária foram conduzidos em um painel de testes especialmente projetado, com carga dinâmica e multímetros da empresa Electrocell. 


\section{RESULTADOS E DISCUSSÃO}

\subsection{CARACTERIZAÇÃO ESTRUTURAL, MORFOLÓGICA E ELETROCATALÍTICA DOS SISTEMAS In, Pt E BINÁRIOS SUPORTADOS EM CARBONO}

Inicialmente, os catalisadores eletroquímicos In/C, Pt/C e PtIn/C e suas diferentes proporções atômicas de metais constituintes, foram sintetizados por meio do método de redução via Borohidreto de Sódio. Após a obtenção dos mesmos, foram caracterizados por técnicas de análise físico-química.

Na FIG. 12 são apresentados os difratogramas dos eletrocatalisadores In/C, Pt/C e PtIn/C, preparados pelo método de redução por Borohidreto de Sódio, para estudos em meio alcalino.

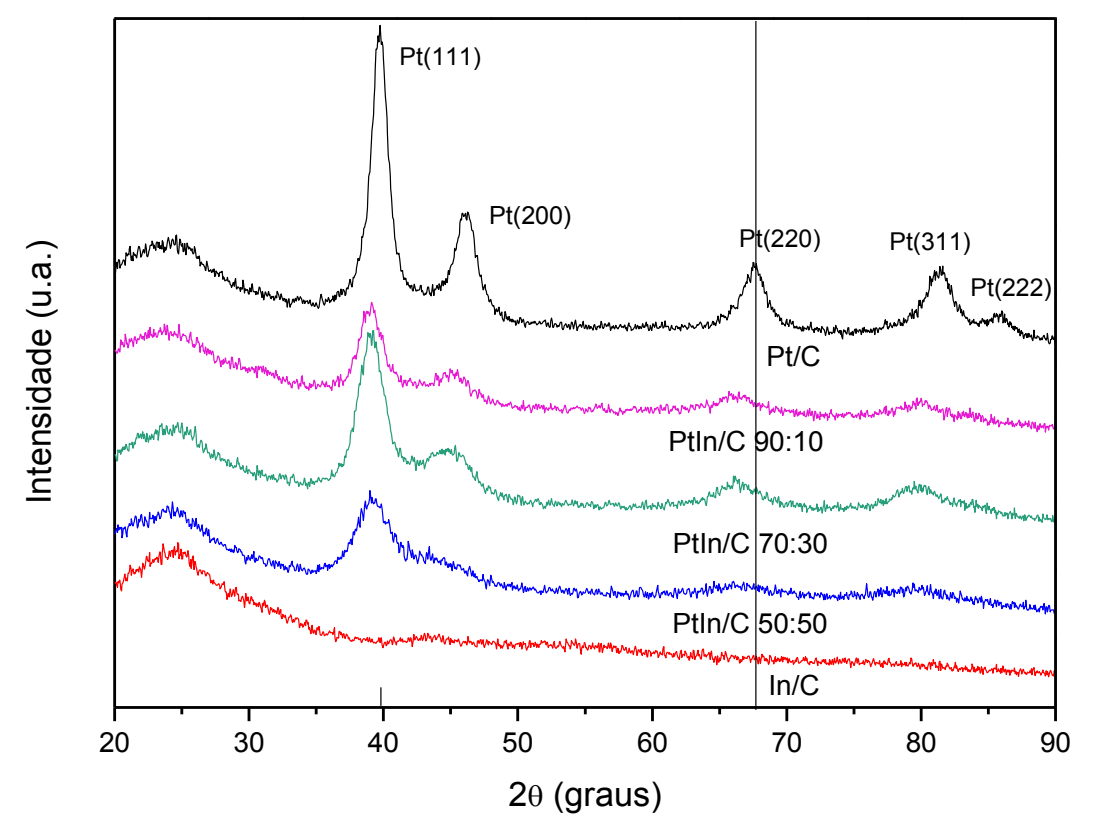

FIGURA 12 - Difratogramas de Raios-X dos eletrocatalisadores Pt/C, PtIn/C e In/C e suas respectivas proporções, preparados pelo método de redução via Borohidreto de Sódio, em um intervalo de $2 \theta$, variando de $20^{\circ}$ a $90^{\circ}$, a uma velocidade de varredura de $2^{\circ}$ min.

Nota-se em todos os difratogramas dos eletrocatalisadores um pico em aproximadamente $2 \theta=25^{\circ}$, associado a estrutura hexagonal do suporte de carbono equivalente a reflexão dos planos (002)[55,56]. Os outros picos observados estão associados aos planos (111), (200), (220), (311) e (222) em aproximadamente $2 \theta=40^{\circ}$, 
$46^{\circ}, 67^{\circ}, 80^{\circ}$ e $85^{\circ}$ respectivamente, os quais são característicos da estrutura cúbica de faces centradas da Platina.

A TAB. 2 apresenta as razões atômicas nominais para os eletrocatalisadores, tamanhos médio dos cristalitos e parâmetros de rede.

TABELA 2 - Razões atômicas nominais, relação atômica de EDX (mol \%), parâmetro de rede e tamanho médio de cristalito dos eletrocatalisadores $\mathrm{Pt} / \mathrm{C}$ e $\mathrm{PtIn} / \mathrm{C}$ preparados pelo método do Borohidreto.

\begin{tabular}{ccccc}
\hline Eletrocatalisadores & $\begin{array}{c}\text { Razão } \\
\text { atômica } \\
\text { nominal }\end{array}$ & $\begin{array}{c}\text { Relação } \\
\text { atômica } \\
\text { EDX }(\mathbf{m o l} \%)\end{array}$ & $\begin{array}{c}\text { Parâmetro } \\
\text { de rede } \\
(\mathbf{n m})\end{array}$ & $\begin{array}{c}\text { Tamanho de } \\
\text { cristalito } \\
(\mathbf{n m})\end{array}$ \\
\hline $\mathrm{Pt} / \mathrm{C}$ & - & - & 0.392 & 5 \\
$\mathrm{PtIn} / \mathrm{C}$ & $90: 10$ & $80: 20$ & 0.399 & 3 \\
$\mathrm{PtIn} / \mathrm{C}$ & $70: 30$ & $76: 24$ & 0.398 & 3 \\
$\mathrm{PtIn} / \mathrm{C}$ & $50: 50$ & $58: 42$ & 0.398 & 3 \\
\hline \hline
\end{tabular}

Para os cálculos de tamanho médio foram selecionados os planos cristalinos de difração correspondente ao plano (220) dos diferentes eletrocatalisadores.

O tamanho médio de cristalito está na faixa de 3,0 e 5,0 nm e a relação atômica de EDX por porcentagem de mol obtida indica que esta metodologia é bastante promissora para a preparação dos eletrocatalisadores propostos. Os eletrocatalisadores $\mathrm{PtIn} / \mathrm{C}$ apresentaram um parâmetro de rede entre 0.399 e $0.398 \mathrm{~nm}$, ou seja, ligeiramente maior que o parâmetro de rede de $\mathrm{Pt} / \mathrm{C}$, apontando uma expansão da rede cristalina causada pela incorporação do Índio (um átomo com raio atômico maior que a Platina), também foi observado o deslocamento dos picos destes eletrocatalisadores para valores inferiores a $2 \theta$ em comparação ao eletrocatalisador Pt/C, sendo este comportamento associado a formação de uma liga metálica entre Platina e Índio [57]. Bryant e colaboradores, realizaram um estudo das ligas de PdIn, PtIn, entre outras, em que mostrou que para o sistema PtIn a fase CFC ordenada da platina foi confirmada, e sucessivamente os átomos de Índio tiveram um diâmetro atômico expandido com uma consequente alteração cristalina. Notaram que os parâmetros de rede destas ligas aumentam linearmente com o aumento do índice de Índio 
na gama de $43-46 \%$ e, em seguida, exibem um ligeiro desvio negativo do comportamento linear inicial. Os espaçamentos de rede atingem o máximo na composição estequiométrica (50\% em In) e depois diminuem rapidamente com adições subsequentes de Índio [57], o que pode ser notado neste estudo.

As imagens obtidas por Microscopia Eletrônica de Transmissão foram usadas para avaliar a distribuição e o tamanho médio das partículas dos eletrocatalisadores de $\mathrm{Pt} / \mathrm{C}$ e PtIn/C preparados pelo método da redução via Borohidreto de Sódio. Os histogramas foram construídos baseados na contagem de cerca de 120 nanopartículas contabilizadas por 8 micrografias de cada sistema eletrocatalítico.

Nas FIG. 13 e 14 são apresentadas as micrografias e o histograma com os tamanhos médio das partículas e sua distribuição para os eletrocatalisadores $\mathrm{Pt} / \mathrm{C}$, PtIn(50:50)/C, PtIn(70:30)/C e PtIn(90:10)/C.

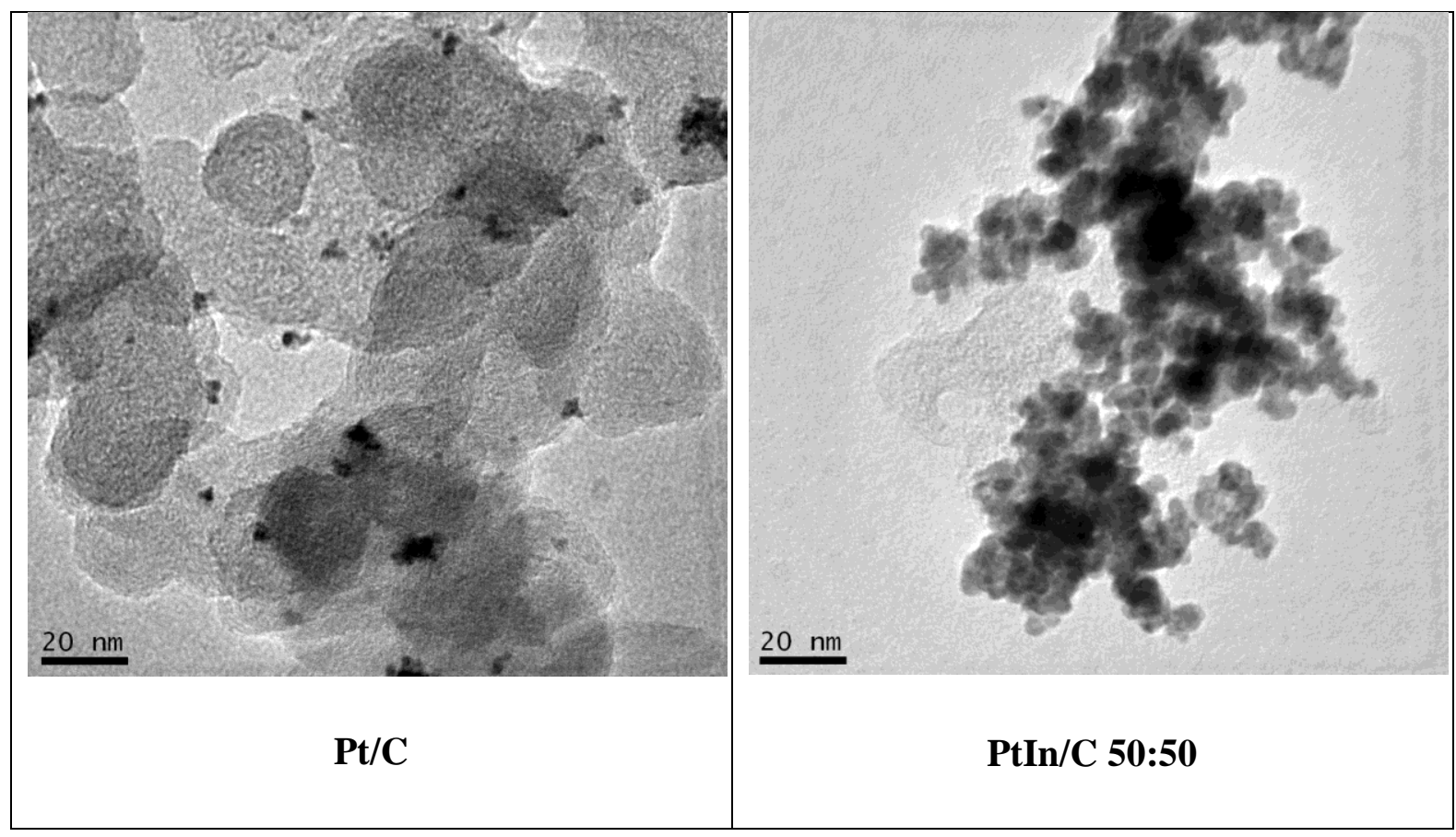




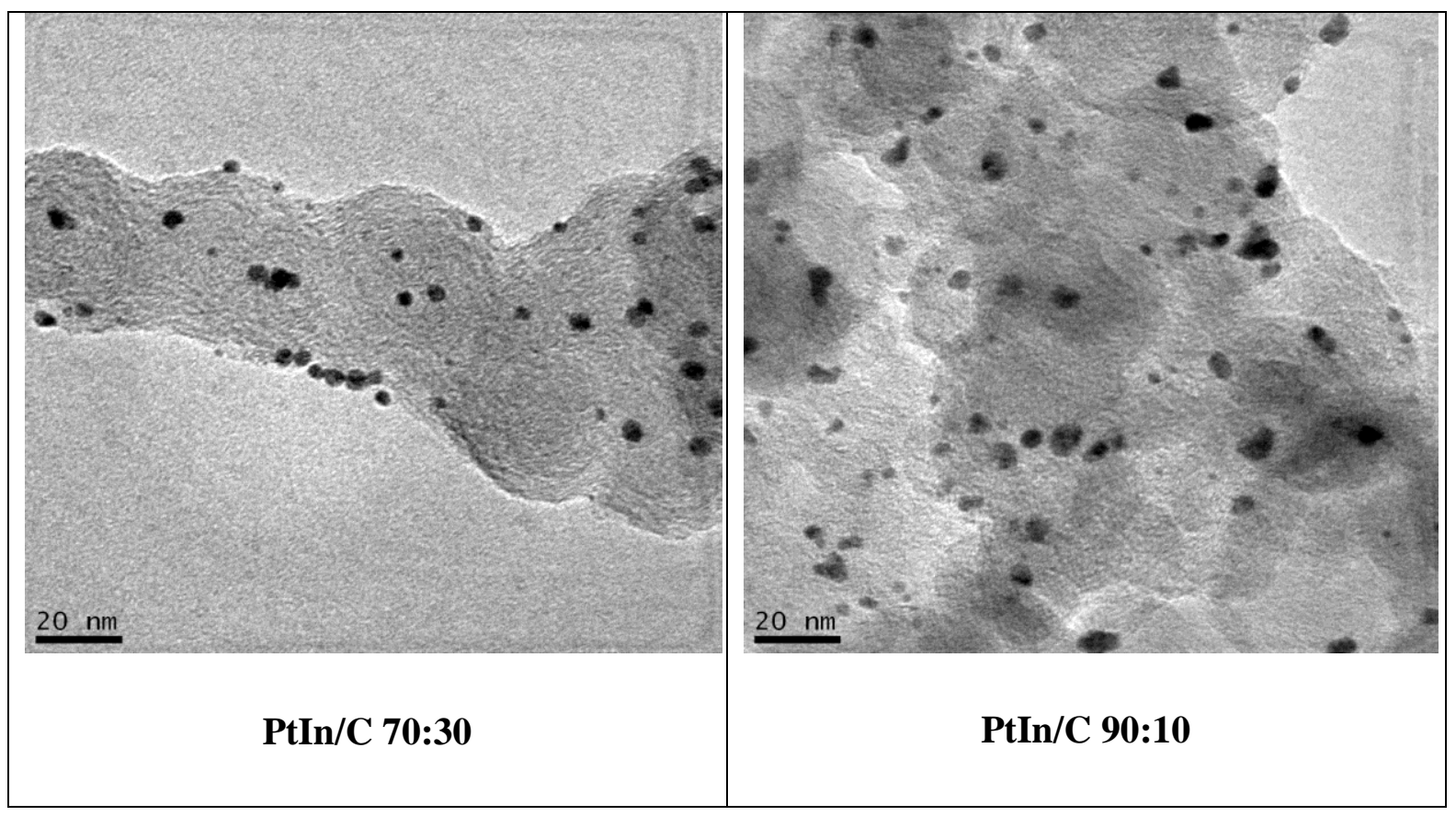

FIGURA 13 - Micrografias obtidas por MET dos catalisadores Pt/C e sistemas binários $\mathrm{PtIn} / \mathrm{C}$.

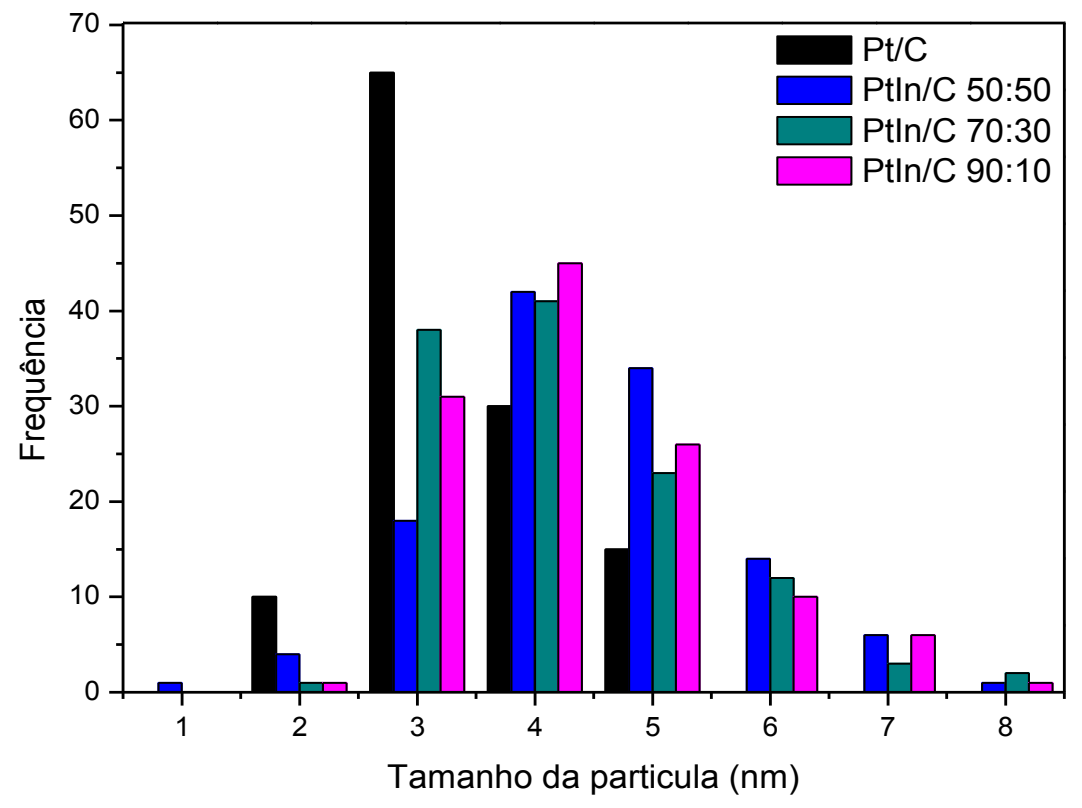

FIGURA 14 - Histograma da distribuição dos tamanhos das partículas dos eletrocatalisadores PtIn/C e suas diferentes composições.

Por meio das micrografias, observa-se que as nanopartículas foram melhor distribuídas no suporte para os eletrocatalisadores com menor proporção de Índio em sua 
composição. Foi observado a formação de aglomerados na micrografia obtida para o sistema eletrocatalítico PtIn/C 50:50, a literatura confirma dificuldades quanto ao preparo de materiais bimetálicos que contem Índio e afirmou que há a formação de aglomerados para composições deste tipo, sintetizadas mesmo por métodos de preparo diferentes do método de redução aplicado neste estudo, estes autores concluíram que tal problema é geralmente causado pela presença do metal na vizinhança da Platina [58], e também que são necessárias mudanças no método de preparo para estes materiais.

Os tamanhos médio das nanopartículas registrados para os eletrocatalisadores Pt/C, PtIn/C 50:50, PtIn/C 70:30 e PtIn/C 90:10 foram, aproximadamente, 2,9 nm, 4,0 nm, $3,7 \mathrm{~nm}$ e 3,8 nm, respectivamente. De acordo com este trabalho, Veizaga [10] expos PtIn/C com tamanhos de nanopartícula de 3,0 nm, mostrando coerência ao resultado obtidos.

Na FIG. 15 são ilustrados os voltamogramas cíclicos, com uma velocidade de varredura de $10 \mathrm{mV} . \mathrm{s}^{-1}$ dos eletrocatalisadores binários preparados com diferentes razões atômicas, ou seja, Pt/C, In/C, PtIn(50:50)/C, PtIn(70:30)/C e PtIn(90:10)/C preparados

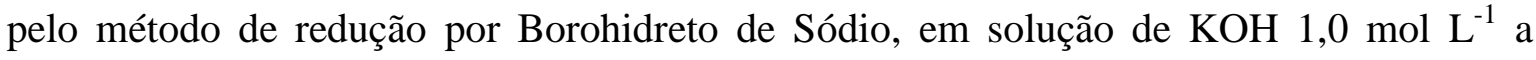
temperatura ambiente. 


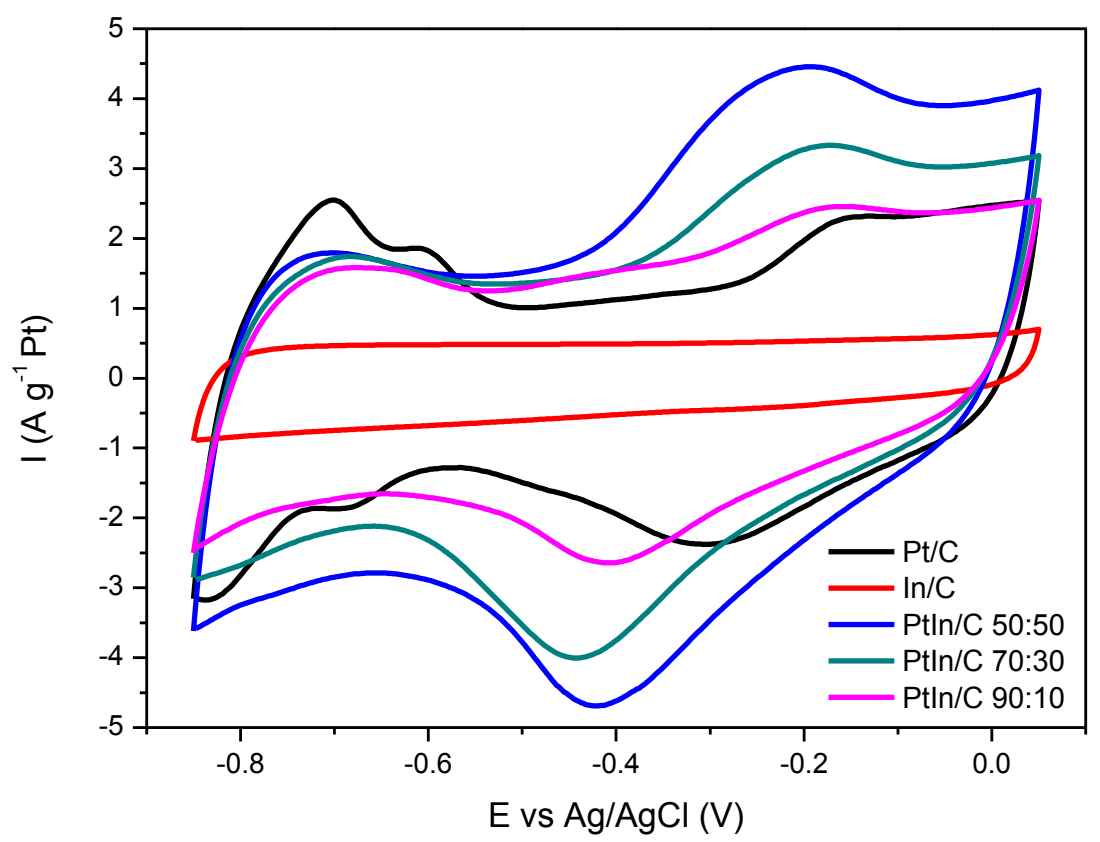

FIGURA 15 - Voltamogramas para os eletrocatalisadores Pt/C, In/C, PtIn/C 50:50, PtIn/C 70:30 e PtIn/C 90:10 obtidos a uma velocidade de $10 \mathrm{mV} . \mathrm{s}^{-1}$, na presença de 1,0 mol.L ${ }^{-1}$ de $\mathrm{KOH}$.

Os voltamogramas cíclicos dos eletrocatalisadores são ilustrados na FIG. 15 onde os resultados foram normalizados pela quantidade de Platina utilizada na composição dos eletrocatalisadores. Em todos os voltamogramas apresentados, a região de adsorção/dessorção de hidrogênio em eletrocatalisadores bimetálicos que contem Índio não está bem definida em relação ao gráfico da Platina pura, este comportamento também é observado para outros eletrocatalisadores binários e ternários sintetizados pelo método de redução via Borohidreto de Sódio [59-60]. Os voltamogramas cíclicos também mostraram que o Índio é inativo para adsorção/dessorção de Hidrogênio. Entre os potenciais de $-0,8$ a $-0,5 \mathrm{~V}$ observa-se que à medida que se aumenta a quantidade de Índio no eletrocatalisador, as correntes na região de adsorção de hidrogênio diminuem, este efeito tem sido atribuído ao impedimento para o Hidrogênio se adsorver sobre sítios de Platina [10]. Para potenciais acima de $-0,4 \mathrm{~V}$ foram observados aumento de corrente para a região de dupla camada elétrica com o aumento de composição mássica de Índio no eletrocatalisador. Portanto, PtIn/C 50:50 apresentou a maior carga/descarga de corrente na região de dupla camada em comparação aos outros eletrocatalisadores preparados. Este efeito já foi observado em 
eletrocatalisadores binários [60]. Na varredura anódica foi observado um pico em torno de $-0,25 \mathrm{~V}$ indicando a formação de óxidos do metal na vizinhança. A corrente de pico aumentou com o aumento do Índio no conteúdo. Este comportamento foi também observado por Rambabu et al. [61] para eletrocatalisadores $\mathrm{Pt} / \mathrm{C}\left(\mathrm{Pt} / \mathrm{C}-\mathrm{In}_{2} \mathrm{O}_{3}\right)$ suportados com $\mathrm{In}_{2} \mathrm{O}_{3}$ preparados para oxidação de etanol em meio ácido.

Na FIG. 16 são ilustrados os resultados da voltametria cíclica para os eletrocatalisadores Pt/C, In/C, PtIn/C 50:50, PtIn/C 70:30 e PtIn/C 90:10 obtidos na presença de 1,0 mol.L ${ }^{-1}$ de $\mathrm{KOH}+1,0$ mol.L ${ }^{-1}$ de metanol.

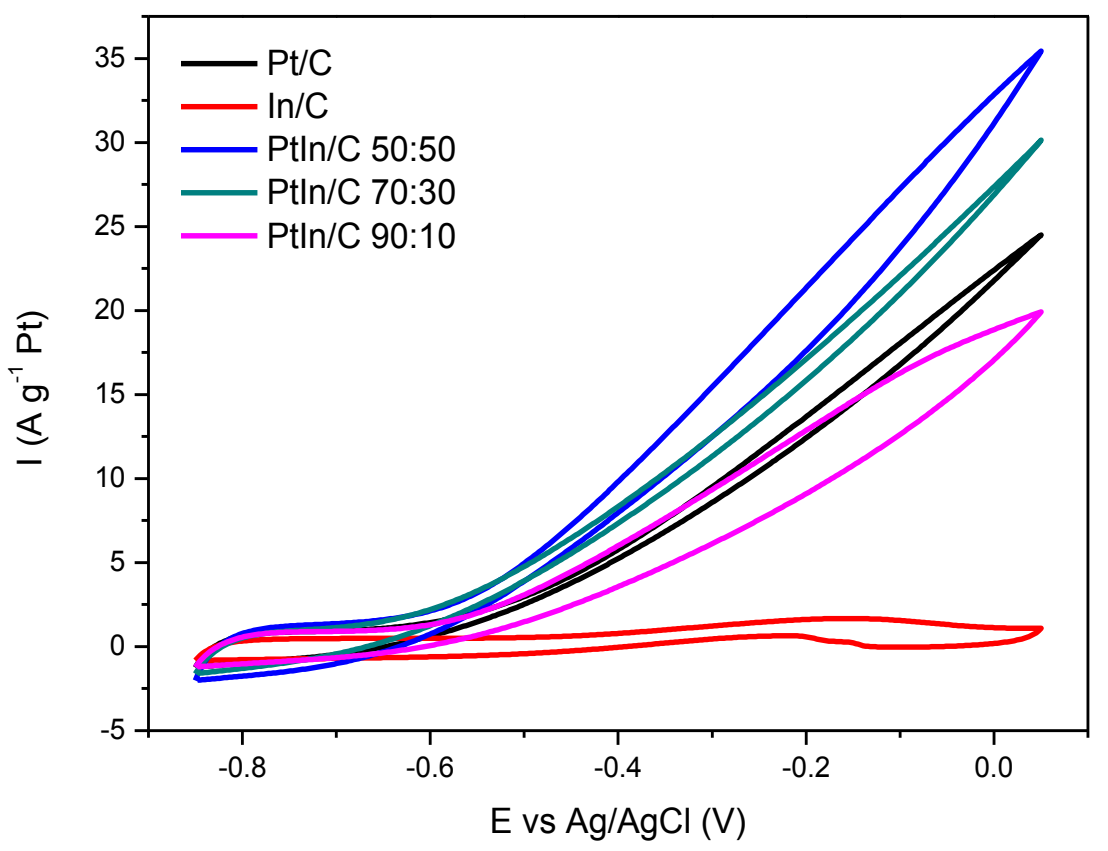

FIGURA 16 - Voltametria cíclica para os eletrocatalisadores de Pt/C, In/C, PtIn/C 50:50, PtIn/C 70:30 e PtIn/C 90:10 obtidos a uma velocidade de $10 \mathrm{mV} . \mathrm{s}-1$, na presença de 1,0 mol.L -1 de KOH e 1,0 mol.L -1 de metanol.

A FIG. 16 ilustra a voltametria cíclica dos sistemas binários sintetizados na presença de metanol, onde os gráficos obtidos foram normalizados pela quantidade de platina que constitui cada sistema. A oxidação do metanol começa com um potencial de cerca de $-0.6 \mathrm{~V}$ para PtIn/C vs cerca de $-0.55 \mathrm{~V}$ para Pt/C. Os estudos para oxidação eletroquímica do metanol em meio alcalino, mostraram que o eletrocatalisador PtIn/C 50:50 apresentou a melhor atividade eletrocatalítica, onde a oxidação iniciou-se em potenciais menos positivos em relação aos demais eletrocatalisadores $(-0,60 \mathrm{~V})$, enquanto 
PtIn/C 90:10 mostrou desempenho semelhante em comparação com $\mathrm{Pt} / \mathrm{C}$ e por fim, o eletrocatalisador In/C foi inativo para a oxidação do metanol. O melhor desempenho do sistema PtIn/C 50:50 pode ser explicado pela oxidação de $\mathrm{CO}_{\mathrm{ads}}$ ou espécies fracamente adsorvidas em outros sítios metálicos, provavelmente provocado pelo segundo metal da vizinhança da Platina como visto na literatura [10]. O sistema In/C mostrou uma baixa atividade em meio alcalino, entretanto, a adição de In à Pt resulta em um aumento na atividade em comparação à Pt pura. Este efeito poderia ser explicado também pelas interações oxi-hidroxi que ocorrem na camada catalítica, onde a presença de espécies oxigenadas de Índio e soluções de $\mathrm{KOH}$ favorecem a oxidação de intermediários adsorvidos, enquanto o efeito eletrônico está associado a formação de ligas PtIn [57, 62].

Na FIG. 17 são ilustrados os resultados de cronoamperometria obtidos no potencial de $-400 \mathrm{mV}$ durante 30 minutos, em solução de 1,0 mol.L ${ }^{-1}$ de metanol em 1,0 mol.L ${ }^{-1}$ de $\mathrm{KOH}$ a temperatura ambiente para todos os eletrolisadores que compõem Índio pelo método de redução via Borohidreto de Sódio.

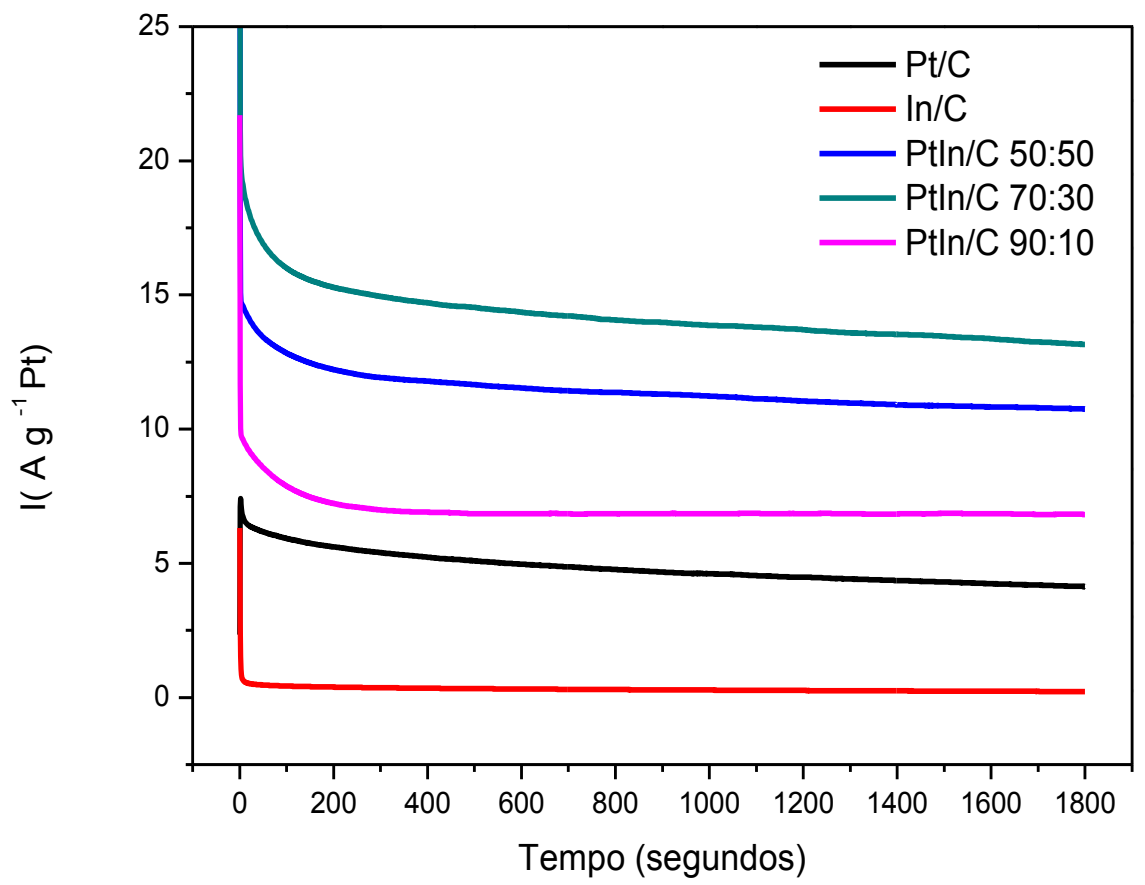

FIGURA 17 - Curva cronoamperométrica para os eletrocatalisadores de $\mathrm{Pt} / \mathrm{C}, \mathrm{In} / \mathrm{C}, \mathrm{PtIn} / \mathrm{C}$ 50:50, PtIn/C 70:30 e PtIn/C 90:10 obtidos na presença de 1,0 mol.L -1 de KOH e 1,0 mol.L -1 de metanol no potencial de $-400 \mathrm{mV}$ durante 30 minutos. 
Durante os primeiros segundos da realização da cronoamperometria, ocorre uma queda acentuada de corrente seguida por uma diminuição/estabilização da mesma durante o restante do tempo. Fato este explicado porque os sítios ativos estão inicialmente livres de moléculas de combustível adsorvidas e oxidadas. A taxa de adsorção de novas moléculas de metanol dependerá da disponibilidade de sítios catalíticos. Assim, a cinética da reação aumentará de acordo com a capacidade dos materiais para oxidarem intermediários responsáveis pelo envenenamento dos sítios catalíticos [21].

Para o teste em meio alcalino os resultados de cronoamperometria mostraram que os eletrocatalisadores $\mathrm{PtIn} / \mathrm{C}$ 70:30 são mais efetivos para oxidação do metanol apresentando melhor atividade catalítica com relação aos demais preparados, entretanto este resultado não está de acordo com o resultado de voltametria cíclica em que PtIn/C 50:50 foi o mais efetivo, vale salientar que a diferença de corrente alcançada neste teste eletroquímico entre ambos apresentou pouca diferença nos valores de correntes quando comparado com os demais eletrocatalisadores. Estes resultados estão de acordo com o aumento das quantidades de hidrogénio quimissorvido encontrado para catalisadores bimetálicos em relação a àqueles monometálicos correspondentes como o $\mathrm{Pt} / \mathrm{C}$ [10]. A melhor atividade dos eletrocatalisadores contendo Índio em sua composição pode ser explicado devido a interação sinérgica entre Pt e $\mathrm{In}_{2} \mathrm{O}_{3}$ e o efeito de superfície das nanopartículas de $\operatorname{In}_{2} \mathrm{O}_{3}$ se mostrando ativo na oxidação de possíveis intermediários correspondendo ao efeito do mecanismo bifuncional [63].

A FIG. 18 ilustra os testes em células a combustível unitárias alimentadas diretamente por metanol para os catalisadores In/C, Pt/C, PtIn/C 50:50, PtIn/C 70:30 e PtIn/C 90:10 em meio alcalino. 

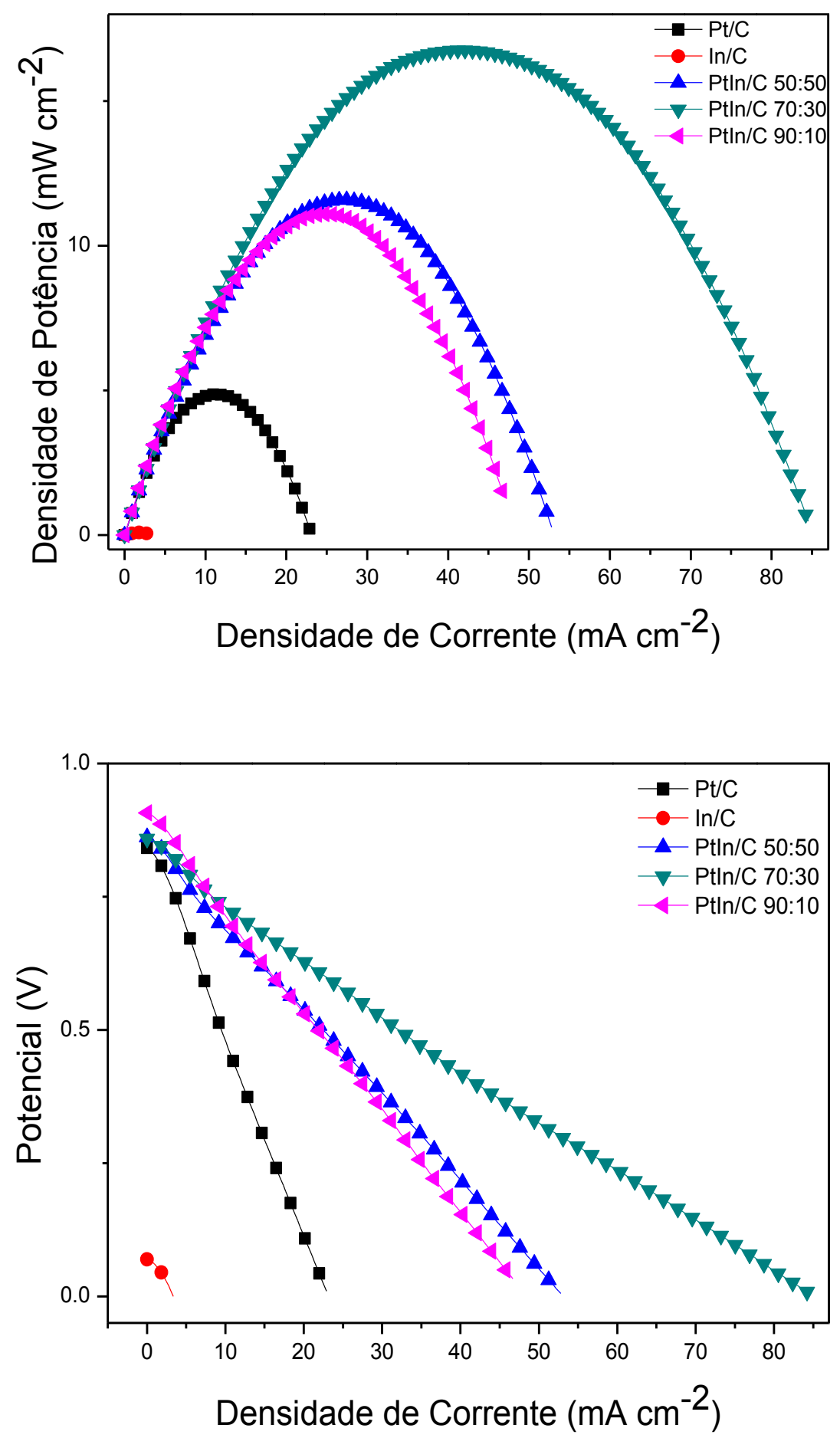

FIGURA 18 - Curvas de polarização para Pt/C, In/C, PtIn/C 50:50, PtIn/C 70:30 e PtIn/C 90:10 no ânodo, utilizando ( $1 \mathrm{mg} \mathrm{Pt} \mathrm{cm} 2$ ), ETEK Pt/C no cátodo e membrana Náfion ${ }^{\circledR}$ 117, fluxo 1 mL min-1 de solução de metanol (2 mol L-1), fluxo de $\mathrm{O} 2$ de $150 \mathrm{~mL}$ min1, temperatura da célula: $80^{\circ} \mathrm{C}$ e temperatura de $\mathrm{H} 2, \mathrm{O} 2: 85^{\circ} \mathrm{C}$. 
Observando as curvas de polarização, nota-se que o potencial de circuito aberto da célula a combustível para PtIn/C 50:50 , PtIn/C 70:30 e PtIn/C 90:10 foram de 0,91, 0,87 e $0,86 \mathrm{~V}$, respectivamente, divergindo por uma diferença de $0,04 \mathrm{~V}$ entre as proporções 50:50 e 70:30 dos resultados eletroquímicos. O eletrocatalisador cuja maior densidade de potência apresentada foi PtIn/C 70:30 resultando em aproximadamente 17 $\mathrm{mW} \mathrm{cm}^{-2}$. Estes resultados estão em acordo parcial com os resultados eletroquímicos, sendo a diferença encontrada no potencial de circuito aberto ser ocasionada pelo fato de que a caracterização eletroquímica é realizada em temperatura ambiente, enquanto os testes em células foram realizados a $80^{\circ} \mathrm{C}$. Resultados semelhantes foram encontrados na literatura para eletrocatalisadores de PtIn/C 70:30 em condições similares, podendo-se inferir assim, não só o papel importante de apoio do Índio no entorno das novas e pequenas partículas, provavelmente por um efeito de decoração do mesmo em torno da Platina, produzindo efeitos promotores importantes tanto para uma mais fácil oxidação de $\mathrm{CO}$ a $\mathrm{CO}_{2}$ quanto para uma atividade eletrocatalítica superior em células tipo PEMFC-DMFC [10].

\subsection{CARACTERIZAÇÃO ESTRUTURAL, MORFOLÓGICA E ELETROCATALÍTICA DOS SISTEMAS Ru, Pt E BINÁRIOS SUPORTADOS EM CARBONO}

Na FIG. 19 são apresentados os difratogramas dos eletrocatalisadores Ru/C, $\mathrm{Pt} / \mathrm{C}$ e $\mathrm{PtRu} / \mathrm{C}$ e suas diferentes proporções atômicas de metais constituintes, preparados pelo método de redução utilizado, para estudos em meio alcalino. 


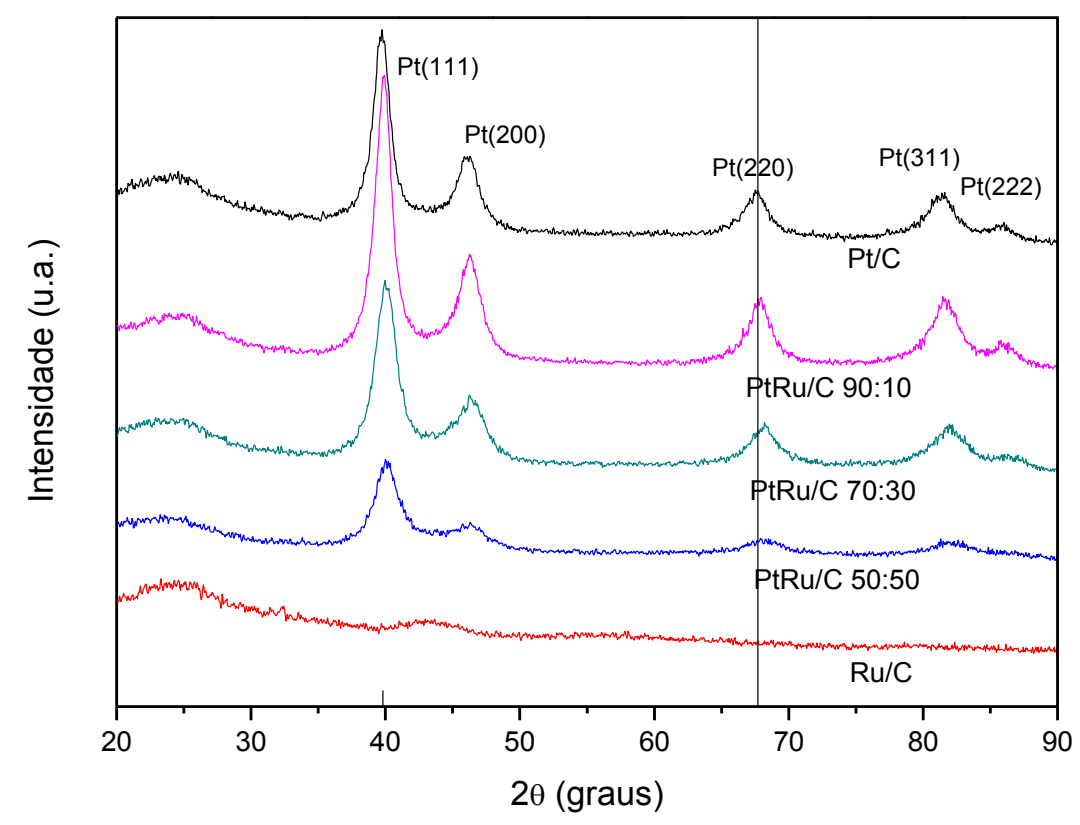

FIGURA 19 - Difratogramas de Raios $X$ dos eletrocatalisadores $\mathrm{Pt} / \mathrm{C}, \mathrm{PtRu} / \mathrm{C}$ e $\mathrm{Ru} / \mathrm{C}$ e suas respectivas proporções, preparados pelo método de redução via Borohidreto de Sódio, em um intervalo de $2 \theta$, variando de $20^{\circ}$ a $90^{\circ}$, a uma velocidade de varredura de $2^{\circ}$ min.

Em todos os difratogramas dos eletrocatalisadores, nota-se um pico em aproximadamente $2 \theta=25^{\circ}$, associado a estrutura hexagonal do suporte de carbono equivalente a reflexão dos planos (002)[55,56], como já citado anteriormente. Os outros picos observados estão associados aos planos (111), (200), (220), (311) e (222) em aproximadamente $2 \theta=40^{\circ}, 47^{\circ}, 68^{\circ}, 82^{\circ}$ e $87^{\circ}$ respectivamente, característicos da estrutura cúbica de faces centradas da Platina. Para os eletrocatalisadores PtRu/C, foram observados deslocamentos para valores de $2 \theta$ um pouco maiores, em comparação com os eletrocatalisadores Pt/C. Este efeito pode estar associado à inclusão de átomos de Rutênio na estrutura cúbica de face centrada da Platina, comportamento que tem sido relacionado à formação de ligas PtRu [49].

A TAB. 3 apresenta as razões atômicas nominais, relação atômica obtida por EDX, tamanhos médio dos cristalitos e parâmetros de rede dos sistemas $\mathrm{Pt} / \mathrm{C}$ e PtRu/C. 
TABELA 3 - Razões atômicas nominais, relação atômica de EDX (mol \%), parâmetro de rede e tamanho médio de cristalito dos eletrocatalisadores $\mathrm{Pt} / \mathrm{C}$ e $\mathrm{PtRu} / \mathrm{C}$ preparados pelo método do Borohidreto.

\begin{tabular}{ccccc}
\hline Eletrocatalisadores & $\begin{array}{c}\text { Razão } \\
\text { atômica } \\
\text { nominal }\end{array}$ & $\begin{array}{c}\text { Relação } \\
\text { atômica } \\
\text { EDX }(\mathbf{m o l} \%)\end{array}$ & $\begin{array}{c}\text { Parâmetro } \\
\text { de rede } \\
(\mathbf{n m})\end{array}$ & $\begin{array}{c}\text { Tamanho de } \\
\text { cristalito } \\
(\mathbf{n m})\end{array}$ \\
\hline $\mathrm{Pt} / \mathrm{C}$ & - & - & 0.392 & 5 \\
$\mathrm{PtRu} / \mathrm{C}$ & $90: 10$ & $89: 11$ & 0.390 & 5 \\
$\mathrm{PtRu} / \mathrm{C}$ & $70: 30$ & $77: 23$ & 0.392 & 5 \\
$\mathrm{PtRu} / \mathrm{C}$ & $50: 50$ & $62: 38$ & 0.388 & 6 \\
\hline \hline
\end{tabular}

Assim, como para os resultados obtidos para os eletrocatalisadores de PtIn/C, a relação atômica de EDX por porcentagem de mol obtida, indica valores semelhantes aos da composição atômica nominal de partida para os eletrocatalisadores $\mathrm{PtRu} / \mathrm{C}$, confirmando ser promissora a preparação deste tipo de eletrocatalisador por meio do método de redução por Borohidreto de Sódio. Os valores dos parâmetros de rede para PtRu/C estão próximos de 0,390, indicando que os átomos de $\mathrm{Ru}$ são adicionados à estrutura de Pt [49], assim como os tamanhos de cristalitos calculados através do pico associado ao plano (220), conforme a tabela 2. Umeda et al. [64] também notaram descolamento para valores de $2 \theta$ superiores dos eletrocatalisadores que apresentavam Rutênio em sua composição quando comparados com os eletrocatalisadores de Platina. Esses autores concluíram que Pt estava bem ligado com $\mathrm{Ru}$, nas condições de síntese utilizadas.

As imagens obtidas por MET foram usadas para avaliar a distribuição e o tamanho médio das partículas dos sistemas $\mathrm{Pt} / \mathrm{C}$ e $\mathrm{PtRu} / \mathrm{C}$ preparados pelo método de redução via Borohidreto de Sódio. Os histogramas foram construídos baseados na contagem de cerca de 120 nanopartículas contabilizadas por 8 micrografias de cada sistema catalítico.

Nas FIG. 20 e 21 são apresentadas as micrografias e o histograma dos eletrocatalisadores Pt/C, PtRu/C 50:50, PtRu/C 70:30 e PtRu/C 90:10. 


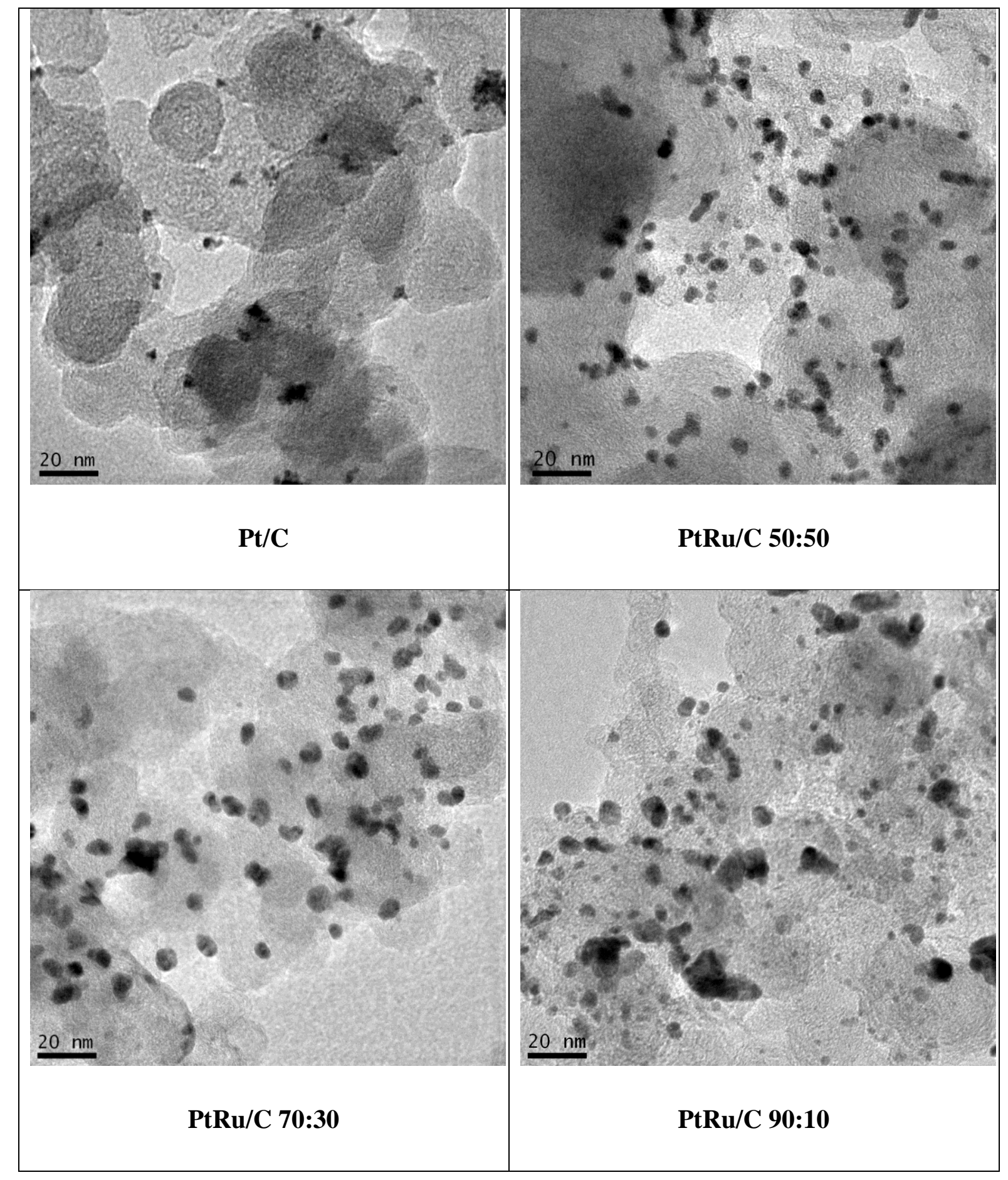

FIGURA 20 - Micrografias obtidas por MET dos catalisadores Pt/C e sistemas binários PtRu/C. 


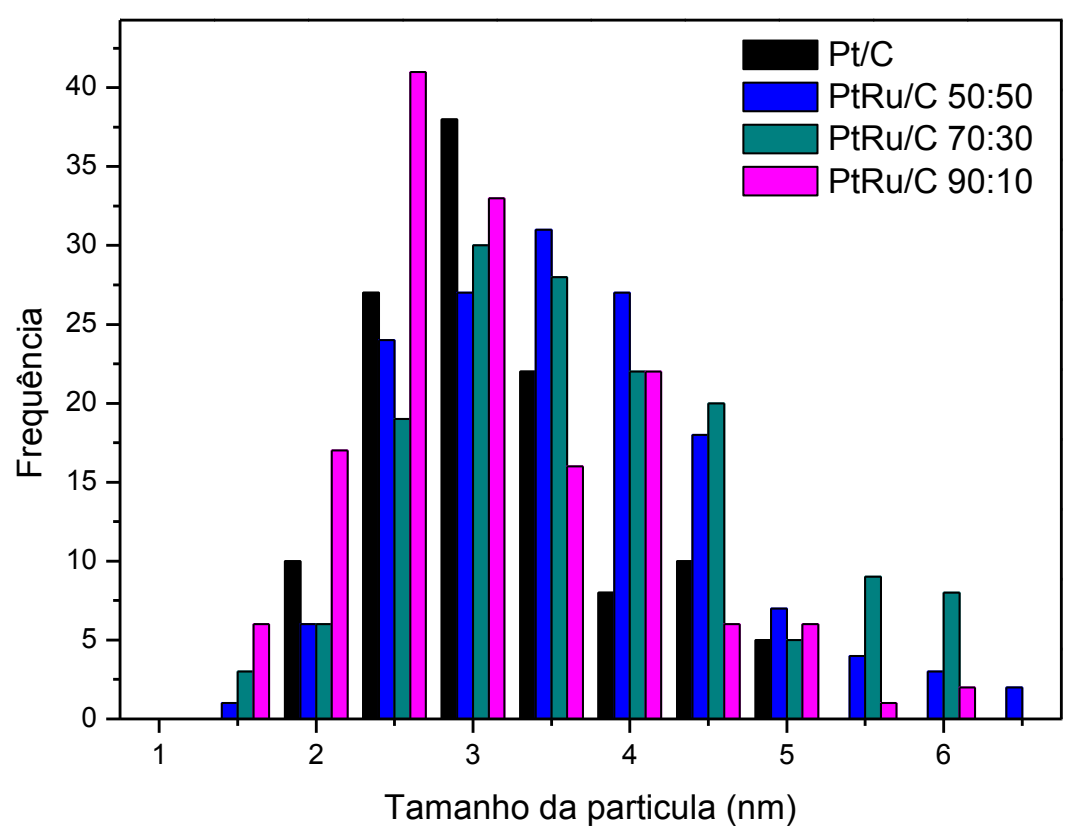

FIGURA 21 - Histograma da distribuição dos tamanhos das partículas dos eletrocatalisadores $\mathrm{PtRu} / \mathrm{C}$ e suas diferentes composições.

As micrografias e histogramas de distribuição do tamanho de partícula, obtidos por MET, ilustradas nas FIG. 20 e 21 mostraram uma boa dispersão das nanopartículas sobre o suporte de carbono. O diâmetro médio das nanopartículas para os eletrocatalisadores $\mathrm{Pt} / \mathrm{C}, \mathrm{PtRu} / \mathrm{C}$ 50:50, PtRu/C 70:30 e PtRu/C 90:10 ficaram na faixa de 2,95 nm, 3,36 nm, 3,46 nm e 2,86 nm respectivamente. Jung et al [65] prepararam eletrocatalisadores $\mathrm{PtRu} / \mathrm{C}$ usando um método de co-impregnação aquoso, com $\mathrm{NaBH}_{4}$ como agente redutor. No trabalho de Jung, as imagens de Microscopia Eletrônica de Transmissão (MET) mostraram partículas esféricas de negro de Carbono na faixa de 10-30 $\mathrm{nm}$ e pontos escuros que medem aproximadamente $2 \mathrm{~nm}$ relacionados às ligas de metal PtRu suportadas no suporte de Carbono.

Na FIG. 22 são mostrados os voltamogramas cíclicos, com uma velocidade de varredura de $10 \mathrm{mV} \cdot \mathrm{s}^{-1}$, dos eletrocatalisadores $\mathrm{Pt} / \mathrm{C}$ e $\mathrm{Ru} / \mathrm{C}$ com variação de proporção mássica dos metais da vizinhança, $\operatorname{PtRu}(50: 50) / C, \operatorname{PtRu}(70: 30) / C$ e $\operatorname{PtRu}(90: 10) / C$ preparados pelo método de redução por Borohidreto de Sódio, em solução de KOH 1,0 mol $\mathrm{L}^{-1}$ a temperatura ambiente. 


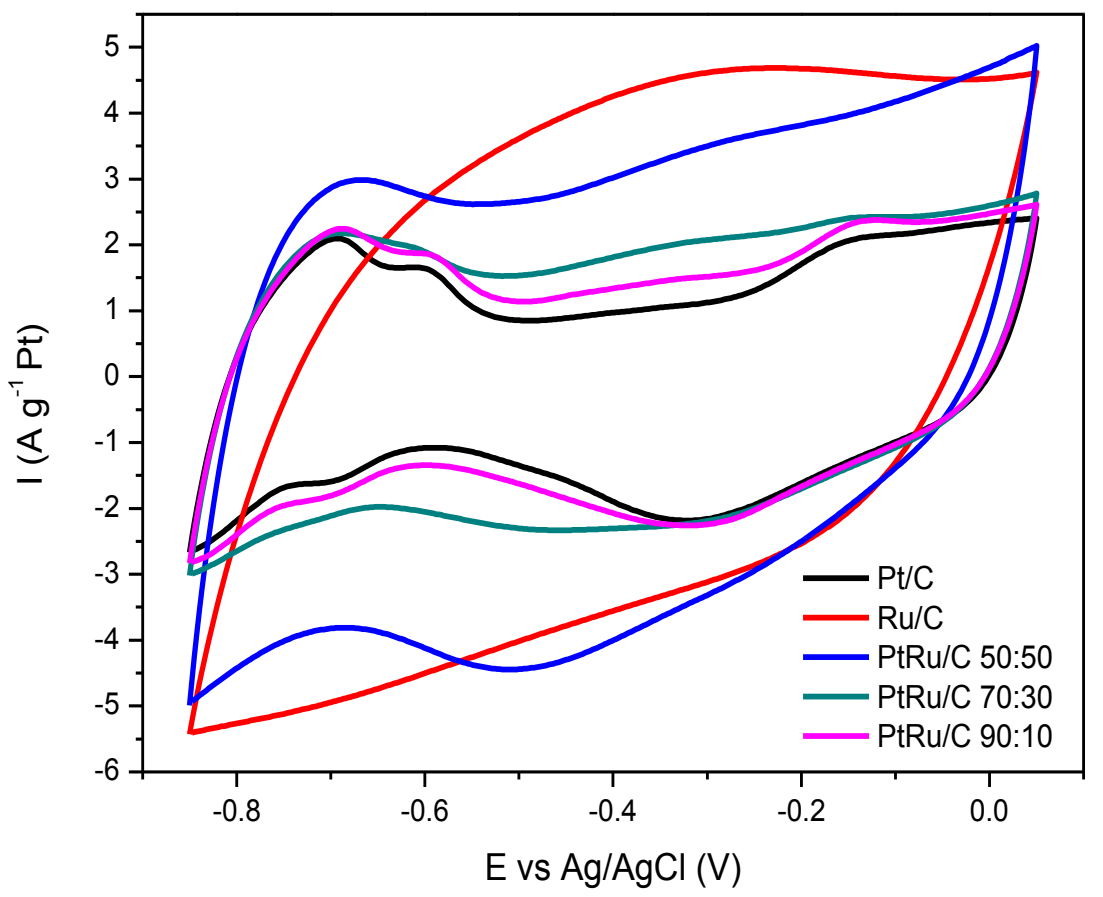

FIGURA 22 - Voltamogramas para os eletrocatalisadores Pt/C, Ru/C, PtRu/C 50:50, $\mathrm{PtRu} / \mathrm{C}$ 70:30 e PtRu/C 90:10 obtidos a uma velocidade de $10 \mathrm{mV}$.s-1, na presença de 1,0 mol.L -1 de KOH.

Os voltamogramas cíclicos dos eletrocatalisadores a base de Rutênio preparados via adição do método de redução por Borohidreto de Sódio também não apresentaram uma região de adsorção/dessorção de Hidrogênio bem definida em comparação com a Platina pura. $\mathrm{O} \mathrm{Ru} / \mathrm{C}$ se apresentou inativo para o processo de adsorção/dessorção de Hidrogênio, no entanto, também foi mostrado um aumento nas correntes na dupla camada, em comparação com Pt/C. O eletrocatalisador PtRu/C 50:50 mostrou um relativo aumento na região de dupla camada elétrica $(-0,4$ a $-0,2 \mathrm{~V})$ para aproximadamente potenciais maiores que $-0,3 \mathrm{~V}$ em relação ao eletrocatalisador de $\mathrm{Pt} / \mathrm{C}$ atribuído a formação de óxidos de Rutênio, sendo este efeito também mais acentuado com uma quantidade crescente de Rutênio em eletrocatalisadores [66]. Kallio et al. [67] mostraram uma formação de camada de hidroxila em Pt que se inicia na região de dupla camada em torno de $0,5 \mathrm{~V}$, seguido pela formação de camada de óxido em potenciais maiores para $\mathrm{PtRu} / \mathrm{C}$ em eletrólito ácido, enquanto que para eletrólito alcalino houve um comportamento similar em que a região de adsorção de Hidrogênio é evidente e a corrente 
de início correspondente à formação de óxido metálico que desloca-se para potenciais mais negativos.

$\mathrm{Na}$ FIG.23 são ilustrados os resultados da voltametria cíclica para os eletrocatalisadores $\mathrm{Pt} / \mathrm{C}, \mathrm{Ru} / \mathrm{C}, \mathrm{PtRu}(50: 50) / \mathrm{C}, \mathrm{PtRu}(70: 30) / \mathrm{C}$ e $\mathrm{PtRu}(90: 10) / \mathrm{C}$ obtidos na presença de 1,0 mol.L ${ }^{-1}$ de $\mathrm{KOH}+1,0$ mol.L ${ }^{-1}$ de metanol.

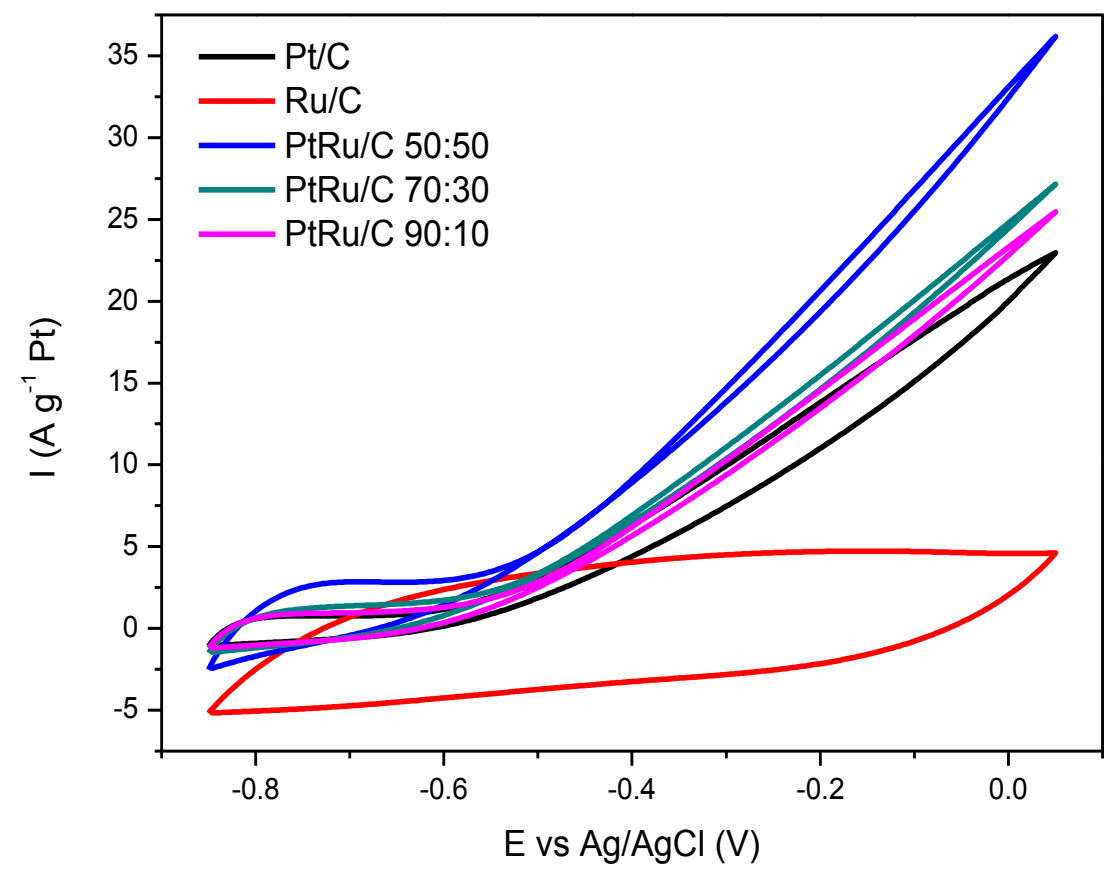

FIGURA 23 - Voltametria cíclica para os eletrocatalisadores de Pt/C, Ru/C, PtRu/C 50:50, $\mathrm{PtRu} / \mathrm{C}$ 70:30 e PtRu/C 90:10 obtidos a uma velocidade de $10 \mathrm{mV}$.s-1, na presença de 1,0 mol.L -1 de KOH e 1,0 mol.L -1 de metanol.

Analisando o voltamograma conforme FIG. 23 o eletrocatalisador PtRu/C 50:50 apresentou-se como o mais efetivo. Sung e colaboradores também mostraram em seu trabalho que eletrocatalisadores com essa mesma proporção de Rutênio tem atividades semelhantes para estudos eletroquímicos frente a oxidação do combustível metanol na faixa de potencial de interesse para células a combustível de baixas temperaturas do tipo PEMFC. O melhor desempenho observado em maiores valores de potencial poderia estar atrelado a atuação do Rutênio através do mecanismo bifuncional, onde as espécies de oxigênio de óxidos de Rutênio podem favorecer a oxidação de intermediários de intoxicação [68], o que mostra que a adição de Ru a Pt é benéfica para a reação de oxidação do metanol e que a razão atômica de Pt e Ru é crucial para otimizar o 
desempenho catalítico [69]. Autores verificaram que o efeito bifuncional é 4 vezes maior do que o efeito eletrônico para a remoção de CO por eletrocatalisadores de Pt decorados com Ru [70], no entanto, o efeito eletrônico associado à formação de ligas PtRu não pode ser desprezado.

Na FIG. 24 são ilustrados os resultados de cronoamperometria obtidos no potencial de $-400 \mathrm{mV}$ durante 30 minutos para todos as proporções sintetizadas com Rutênio neste estudo, pelo método de redução via Borohidreto de Sódio. Essas cronoamperometrias foram realizadas em solução de 1,0 mol.L ${ }^{-1}$ de metanol em 1,0 mol.L ${ }^{-1}$ de $\mathrm{KOH}$ a temperatura ambiente.

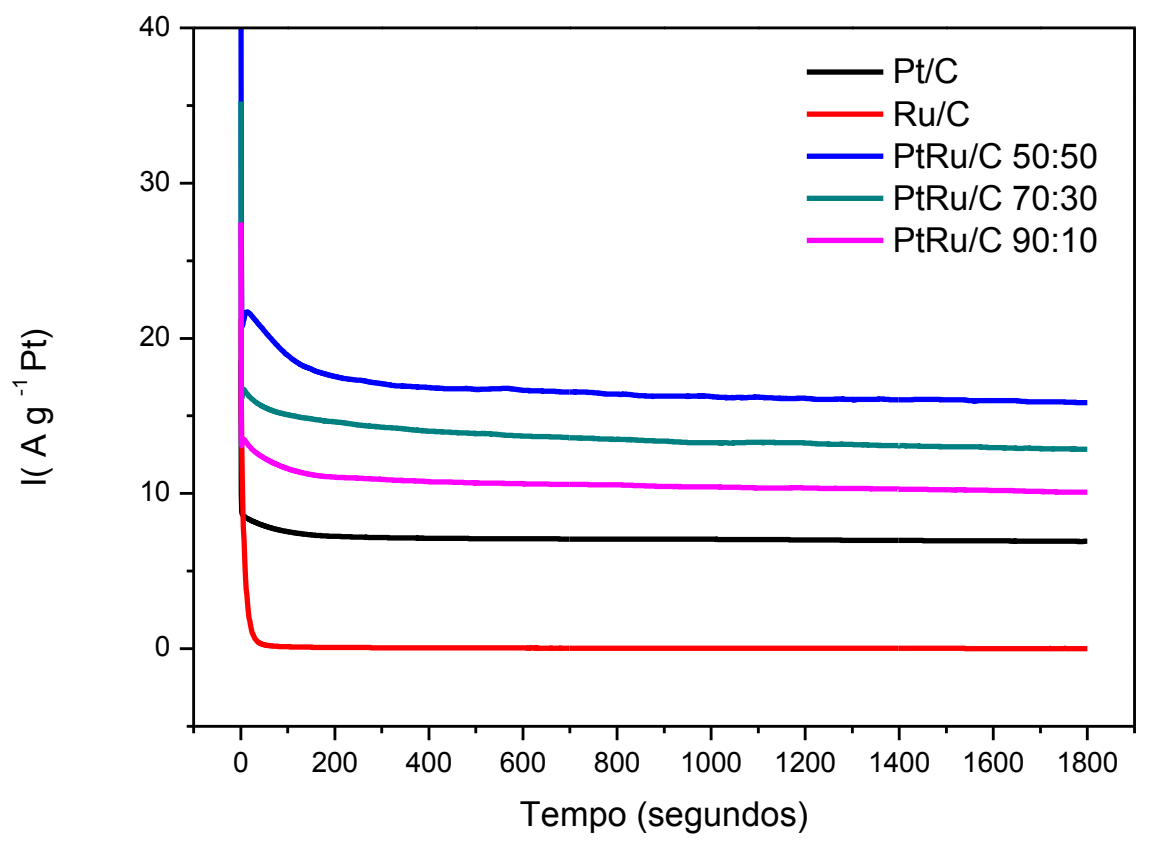

FIGURA 24 - Curva cronoamperométrica para os eletrocatalisadores de $\mathrm{Pt} / \mathrm{C}, \mathrm{Ru} / \mathrm{C}$, $\mathrm{PtRu} / \mathrm{C}$ 50:50, PtRu/C 70:30 e PtRu/C 90:10 obtidos na presença de 1,0 mol.L -1 de KOH e 1,0 mol.L -1 de metanol no potencial de $-400 \mathrm{mV}$ durante 30 minutos.

Os resultados obtidos com a técnica de cronoamperometria confirmaram o que foi observado nos resultados de voltametria cíclica do mesmo. Estudos já realizados mostraram que o Rutênio como metal acessório junto a Platina em eletrocatalisadores bimetálicos é mais eficiente para oxidação do metanol do que para o etanol por exemplo, pela complexibilidade da sua molécula, mesmo estes sistemas sendo preparados por métodos de redução diferentes [71] ou em meio ácido [68,71]. 
A FIG. 25 ilustra os testes em células a combustível unitárias alimentadas diretamente por metanol para os sistemas $\mathrm{Pt} / \mathrm{C}$ e PtRu/C em meio alcalino.
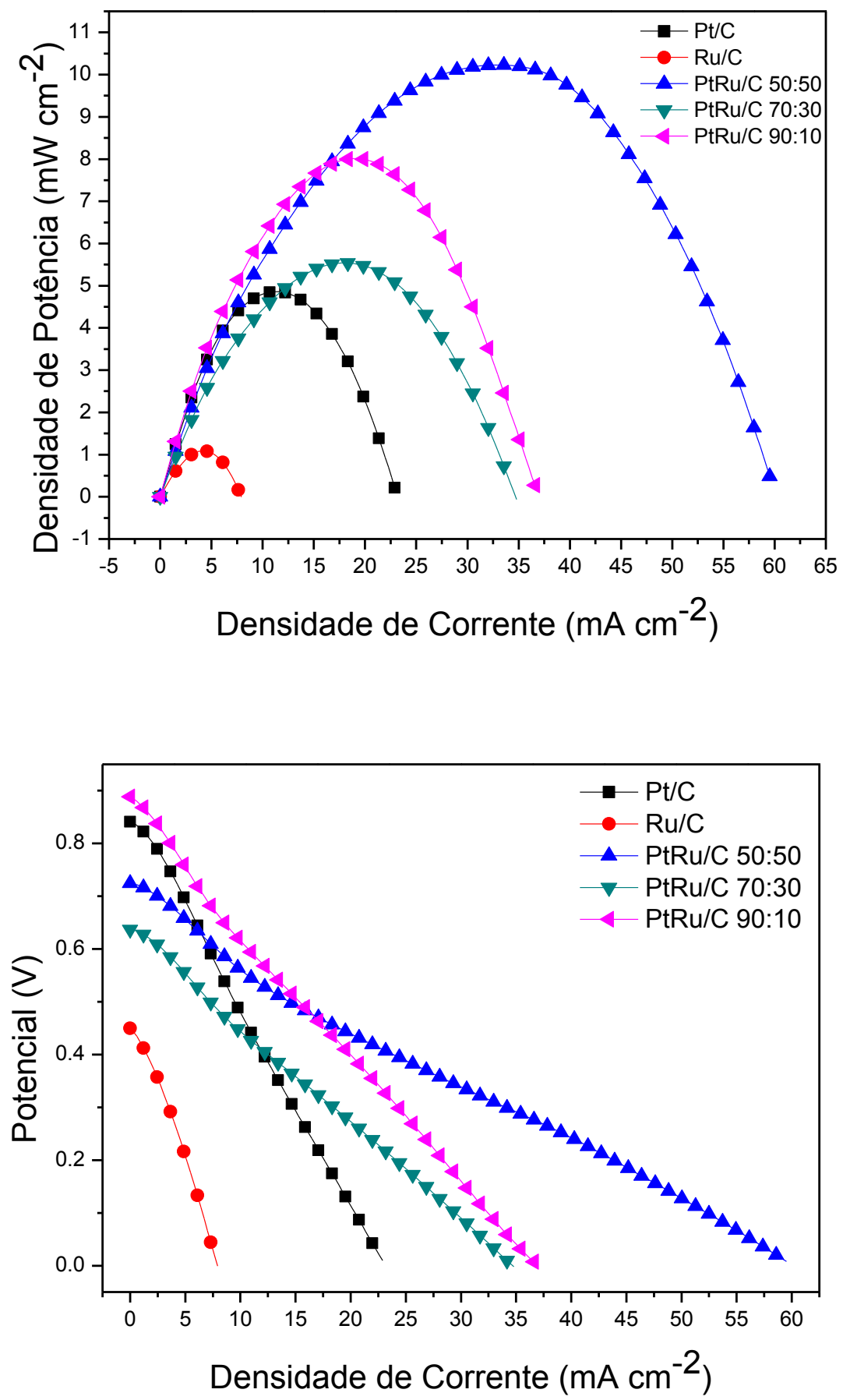

FIGURA 25 - Curvas de polarização para Pt/C, Ru/C, PtRu/C 50:50, PtRu/C 70:30 e $\mathrm{PtRu} / \mathrm{C}$ 90:10 no ânodo utilizando $(1 \mathrm{mg} \mathrm{Pt} \mathrm{cm2)} \mathrm{e} \mathrm{ETEK} \mathrm{Pt} \mathrm{/} \mathrm{C} \mathrm{no} \mathrm{cátodo} \mathrm{e} \mathrm{Náfion®} 117$ como membrana, a $80^{\circ} \mathrm{C}$, fluxo $\sim 1 \mathrm{~mL} \mathrm{~min}^{-1}$ de solução de metanol $\left(2 \mathrm{~mol} \mathrm{~L}{ }^{-1}\right)$, fluxo de $\mathrm{O}_{2}$ de $150 \mathrm{~mL} \mathrm{~min}^{-1}$. 
O eletrocatalisador PtRu/C 50:50 apresentou o maior valor de densidade de potência obtido de aproximadamente $10 \mathrm{~mW} \mathrm{~cm}^{-2}$ de acordo com voltametria cíclica e resultados de cronoamperometria. As curvas de polarização apresentaram potenciais de circuito aberto para PtRu/C 90:10 e Pt/C em torno de 0,88 e 0,84 V, respectivamente, apresentando desacordo com os resultados eletroquímicos. A proporção 50:50 foi encontrada como um ótimo resultado na literatura também em ensaios de curvas de polarização em meio ácido em que a membrana utilizada é a mesma deste ensaio, cuja característica é a condução de prótons, fato este que facilita a oxidação do combustível em ensaios ricos em íons $\mathrm{H}^{+}$[72].

Os valores de circuito aberto obtidos para o sistema PtRu/C 50:50 e 70:30, inferiores aos de melhor desempenho, podem ser justificados por problemas de prensagem e descolamento de MEA's destes sistemas eletrocatalíticos, fato que interferiu na performance de ambos quando utilizados na célula do tipo DMFC. Portanto, o desenvolvimento de novas membranas aniônicas são fortemente encorajados pelos resultados promissores dos experimentos eletroquímicos. Neste contexto, Sun et al [73] mostraram que o grupo funcional 1,2-metilimidazólio tem aplicação potencial para AAEMs em AAEMFCs.

\subsection{CARACTERIZAÇÃO ESTRUTURAL, MORFOLÓGICA E ELETROCATALÍTICA DOS SISTEMAS TERNÁRIOS PtRuIn SUPORTADOS EM CARBONO}

Os sistemas eletroquímicos $\mathrm{PtRuIn/C}$ e as diferentes proporções atômicas 50:10:40, 50:25:25, 50:40:10, 70:20:10 e 90:05:05, foram sintetizados por meio do método de redução via Borohidreto de Sódio e comparados perante o catalisador Pt/C sintetizado pela mesma metodologia. Após a obtenção ao término da síntese, os mesmos foram caracterizados por analises físico-química.

Na FIG. 26 são apresentados os difratogramas dos eletrocatalisadores ternários, preparados pelo método de redução por Borohidreto de Sódio, para estudos em meio alcalino. 


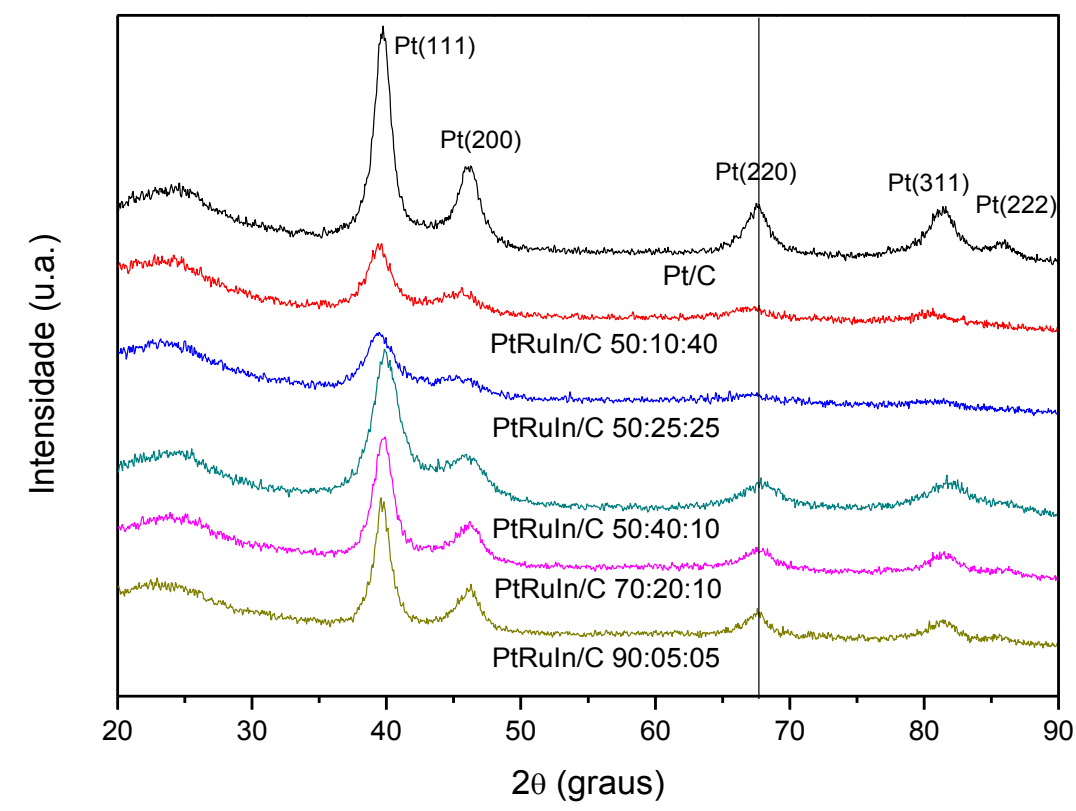

FIGURA 26 - Difratogramas de Raios $\mathrm{X}$ dos eletrocatalisadores $\mathrm{Pt} / \mathrm{C}$ e os sistemas ternários e suas respectivas proporções, preparados pelo método de redução via Borohidreto de Sódio, em um intervalo de $2 \theta$, variando de $20^{\circ}$ a $90^{\circ}$, a uma velocidade de varredura de $2^{\circ}$ min.

Em todos os difratogramas apresentados na FIG. 26, nota-se um pico em aproximadamente $2 \theta=25^{\circ}$, associado ao suporte de carbono e sua estrutura hexagonal equivalente a reflexão dos planos (002), conforme discutido em tópico anterior [55,56]. Os outros picos observados estão associados aos planos (111), (200), (220), (311) e (222) em aproximadamente $2 \theta=39^{\circ}, 47^{\circ}, 68^{\circ}, 83^{\circ}$ e $88^{\circ}$ respectivamente indicando a existência de cristalitos nanométricos, característicos da estrutura CFC da Platina e suas ligas. Notou-se um leve deslocamento para valores menores que $2 \theta$ para ternários com maior composição de In no sistema e um leve deslocamento para valores maiores que $2 \theta$ para catalisadores com maior proporção de $\mathrm{Ru}$, coerente com o comportamento dos sistemas binários PtIn e $\mathrm{PtRu}$. Kucernak et al., obteve comportamentos semelhantes em seus estudos com sistemas ternários PtRuSn, em que pode-se ver claramente a partir do ajuste gaussiano do pico de reflexão da Pt (220) que o ângulo é deslocado para valores mais elevados de $2 \theta$ quando somente $\mathrm{Ru}$ foi incorporado em Pt, mas a adição de $\mathrm{Sn}$ a PtRu tinha conduzido a uma mudança do pico para valores de ângulo inferior [74], o que faz este estudo considerar, que o átomo de Índio se comporta de forma semelhante ao átomo de Sn. 
A TAB. 4 apresenta as razões atômicas nominais, relação atômica obtida por EDX, tamanhos médio dos cristalitos e parâmetros de rede dos sistemas $\mathrm{Pt} / \mathrm{C}$ e ternários PtRuIn/C.

TABELA 4 - Razões atômicas nominais, relação atômica de EDX (mol \%), parâmetro de rede e tamanho médio de cristalito dos eletrocatalisadores $\mathrm{Pt} / \mathrm{C}$ e os sistemas ternários $\mathrm{PtRuIn/C}$ preparados pelo método de redução via Borohidreto de Sódio.

\begin{tabular}{ccccc}
\hline \hline Eletrocatalisadores & $\begin{array}{c}\text { Razão } \\
\text { atômica } \\
\text { nominal }\end{array}$ & $\begin{array}{c}\text { Relação } \\
\text { atômica } \\
\text { EDX }(\mathbf{m o l} \%)\end{array}$ & $\begin{array}{c}\text { Parâmetro } \\
\text { de rede } \\
(\mathbf{n m})\end{array}$ & $\begin{array}{c}\text { Tamanho de } \\
\text { cristalito } \\
(\mathbf{n m})\end{array}$ \\
\hline Pt/C & - & - & 0.392 & 5 \\
PtRuIn/C & $50: 10: 40$ & $71: 13: 16$ & 0.396 & 3 \\
PtRuIn/C & $50: 25: 25$ & $61: 23: 16$ & 0.397 & 2 \\
PtRuIn/C & $50: 40: 10$ & $63: 31: 06$ & 0.390 & 3 \\
PtRuIn/C & $70: 20: 10$ & $80: 16: 04$ & 0.392 & 4 \\
PtRuIn/C & $90: 05: 05$ & $93: 05: 02$ & 0.393 & 5 \\
\hline \hline
\end{tabular}

Os tamanhos médio de cristalitos obtidos calculados através do pico associado ao plano (220), estão na faixa de 2,0 a 5,0 nm, indicando que a rota de síntese via Borohidreto de Sódio é satisfatória diante a preparação dos eletrocatalisadores para estudos frente a oxidação do metanol. Os valores dos parâmetros de rede para os ternários PtRuIn/C com composições 50:10:40 e 50:25:25 se mostraram maiores do que o valor encontrado para o sistema $\mathrm{Pt} / \mathrm{C}$, fato este justificado pela maior proporção do átomo de Índio em sua composição, que possui raio atômico maior que a Platina e o Rutênio, confirmando a possibilidade de formação de liga, de acordo com autores [74] que estudaram um sistema ternário de atuação semelhante. Para o sistema PtRuIn/C 50:40:10, nota-se uma contração do parâmetro de rede pela inserção de maior quantidade de Rutênio (átomo de menor raio atômico no sistema). Para os sistemas eletrocatalíticos PtRuIn/C 70:20:10 e 90:05:05 o parâmetro de rede se manteve igual ou próximo a 0,392 nm característico do catalisador $\mathrm{Pt} / \mathrm{C}$, semelhança que se deve a maior composição de $\mathrm{Pt}$ nesses sistemas. 
Os resultados por porcentagem de mol obtidos pelo EDX, para os eletrocatalisadores de PtRuIn/C, indicaram um resultado satisfatório para o sistema de composição elementar 90:05:05 comprovando a eficiência do método de redução empregado, para os outros eletrocatalisadores, valores pouco divergentes aos da composição atômica nominal de partida foram resultados, esta divergência pode estar atrelada a voltagem do equipamento que só opera até $20 \mathrm{keV}$. Equipamentos que operam com voltagens mais altas (até $60 \mathrm{keV}$ ), por exemplo, permitem a excitação das camadas $\mathrm{K}$ até elementos razoavelmente pesados com maior facilidade, evitando que a analise se limite às camadas $\mathrm{L}$ ou $\mathrm{M}$ desses elementos, que são mais fracas, menos diferenciadas $\mathrm{e}$ que podem estar sobrepostas a outras camadas de elementos mais leves [75].

Para o caso dos eletrocatalisadores ternários, se fez a importância de analisar os espectros obtidos por EDX, para a observação dos elementos inseridos no sistema catalítico, já que em sua maioria não obedeceram a razão atômica nominal de partida.

Os espectros dos eletrocatalisadores PtRuIn/C sintetizados, são apresentados na FIG. 27, a seguir.

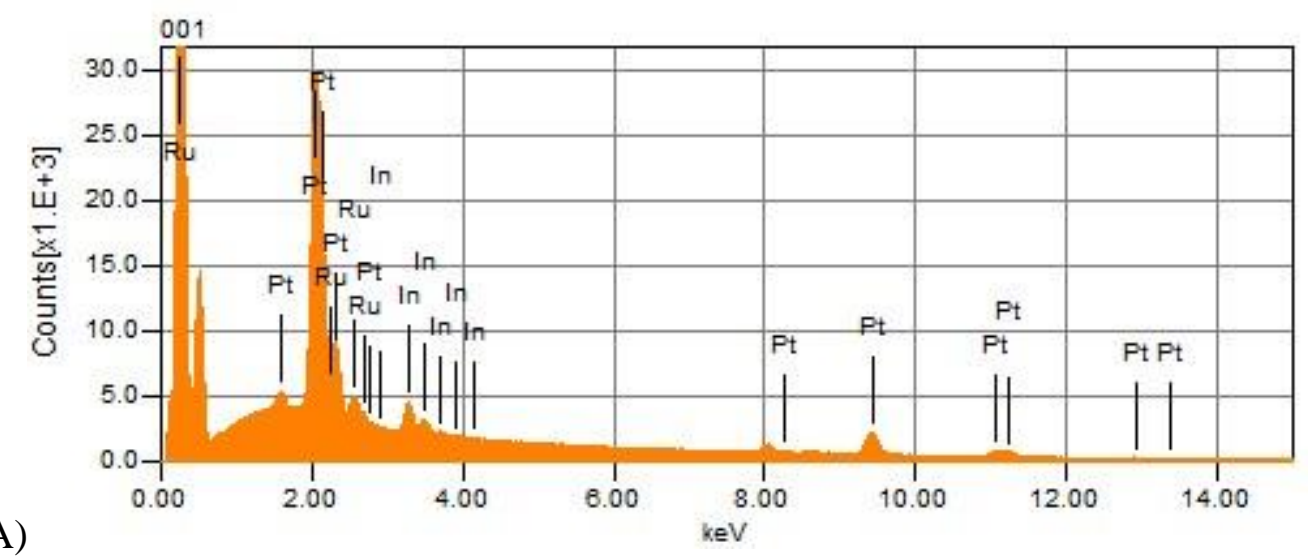

(A) 


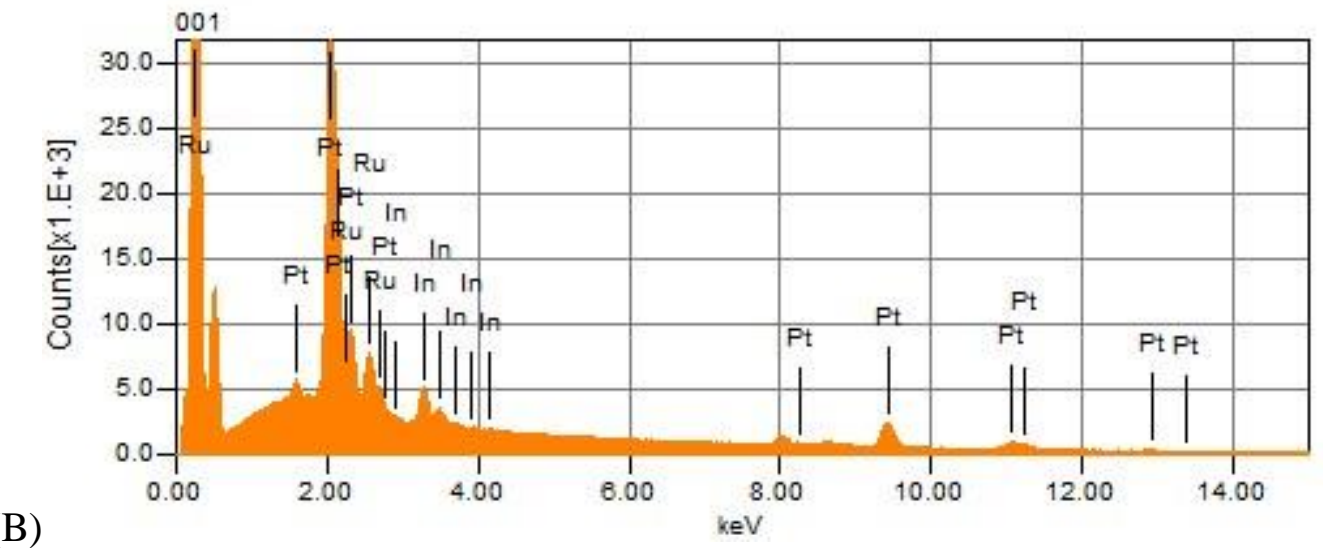

(C)
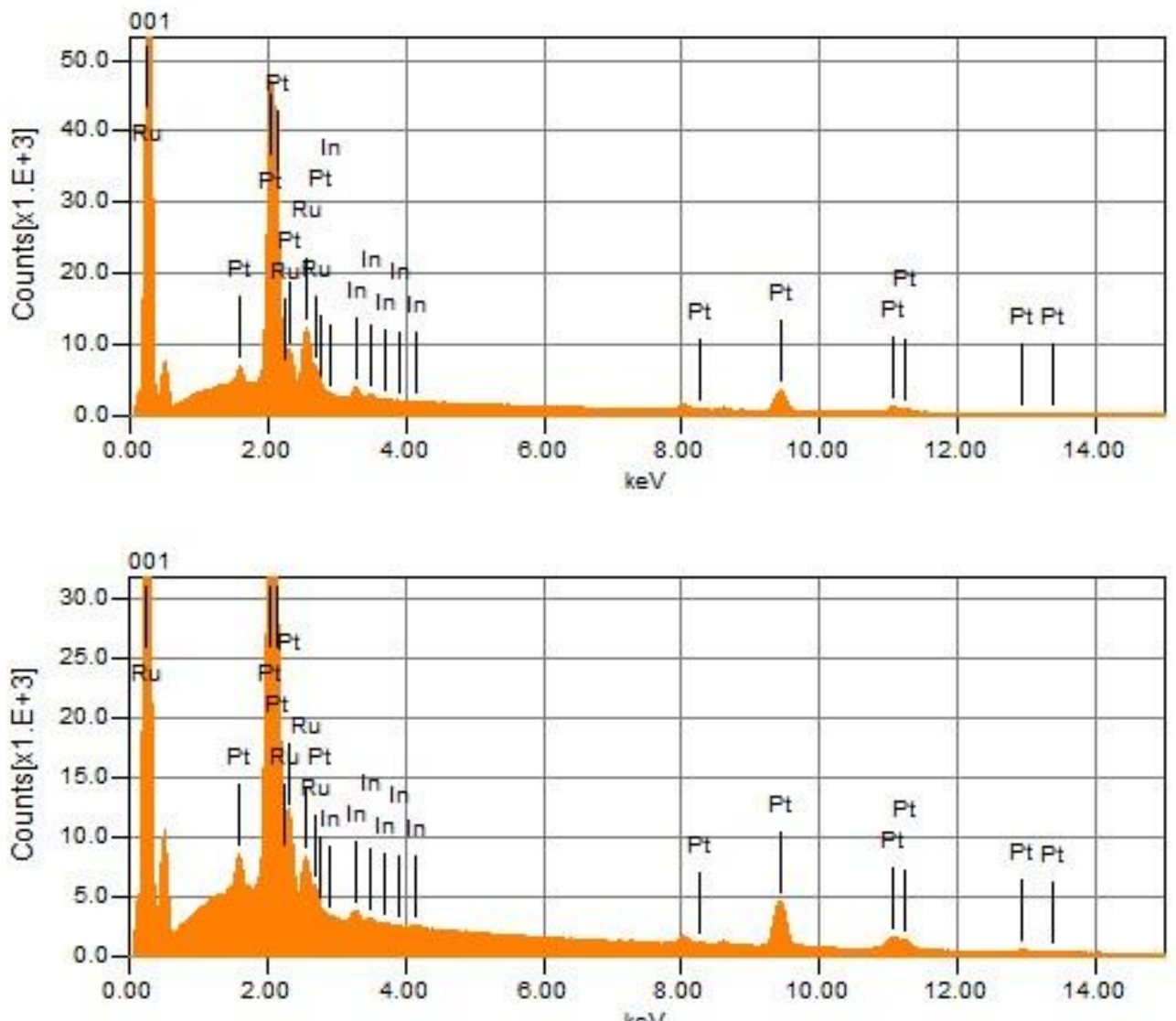

(D) keV 
(E)

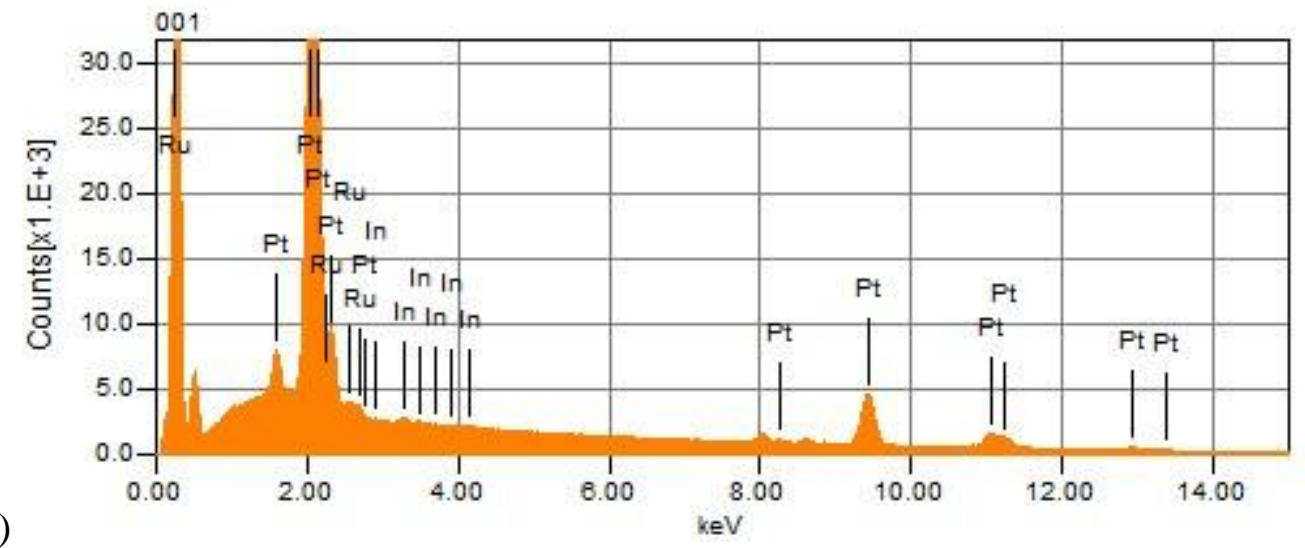

FIGURA 27 - Espectros de distribuição dos elementos constituintes dos eletrocatalisadores obtidos por EDX: A) PtRuIn/C 50:10:40, B) PtRuIn/C 50:25:25, C) PtRuIn/C 50:40:10, D) PtRuIn/C 70:20:10 e E) PtRuIn/C 90:05:05 preparados pelo método de redução via Borohidreto de Sódio.

Em todos os espectros obtidos pela técnica de EDX, as respostas de Carbono utilizado como suporte foram omitidas, devido a intensidade do sinal ser muito intenso, quando comparado aos metais que compõem o eletrocatalisador, dificultando a resposta da identificação das proporções atômicas de metais dos eletrocatalisadores propostos (PtRuIn) [76]. Nos espectros obtidos pode-se observar os picos relativos aos metais presentes e principalmente a evidência das regiões em que a Pt se localiza, sugerindo uma possível cobertura dos átomos de Pt sobre Ru e In ou a sobreposição das intensidades das bandas dos metais obtidas por EDX.

As imagens obtidas por Microscopia Eletrônica de Transmissão, apresentadas na FIG. 28, mostram em detalhes a disposição das nanopartículas dos metais dos sistemas ternários PtRuIn/C e sua organização. Os histogramas foram construídos baseados na contagem de cerca de 120 nanopartículas contabilizadas por 8 micrografias de cada eletrocatalisador. 


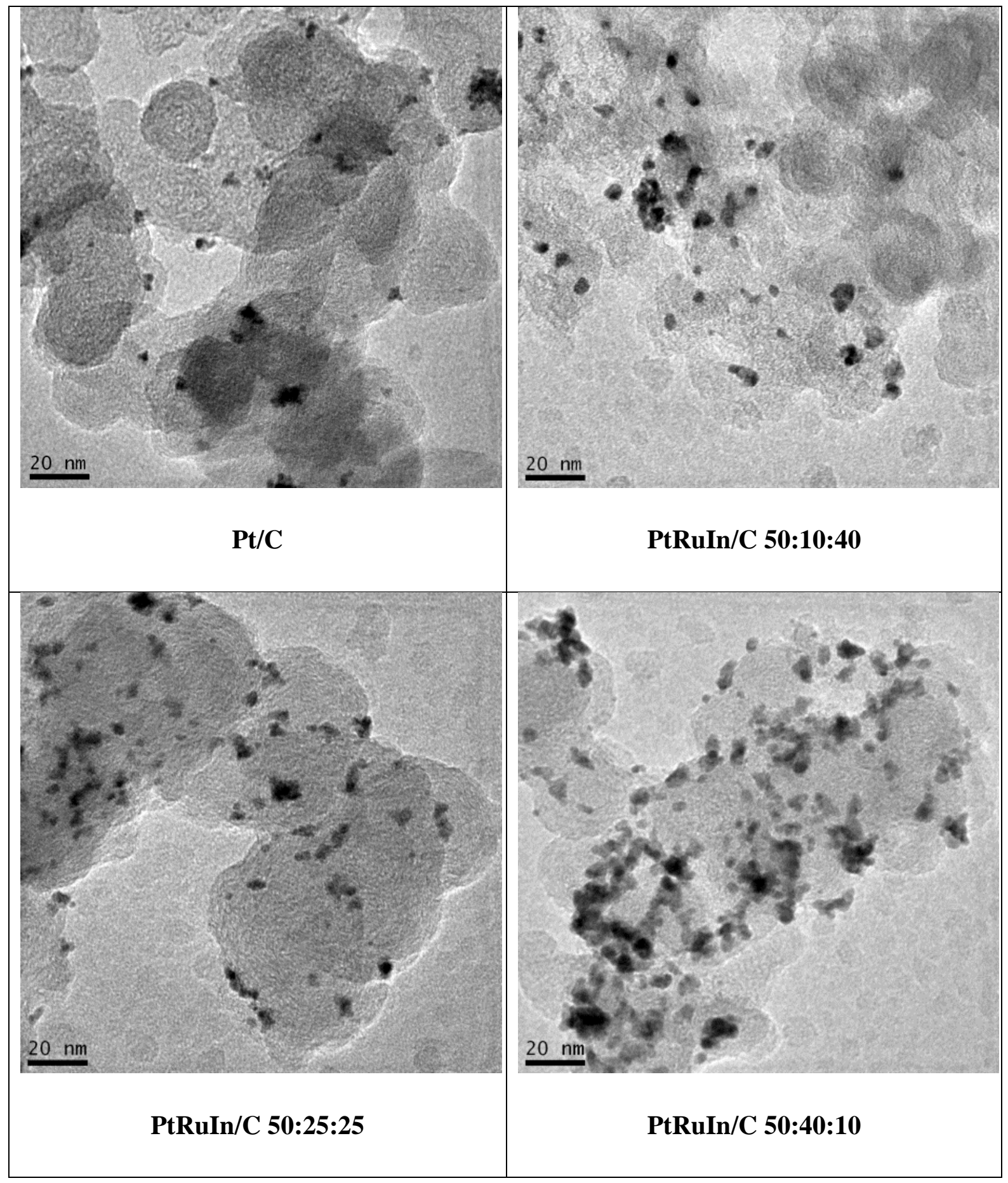




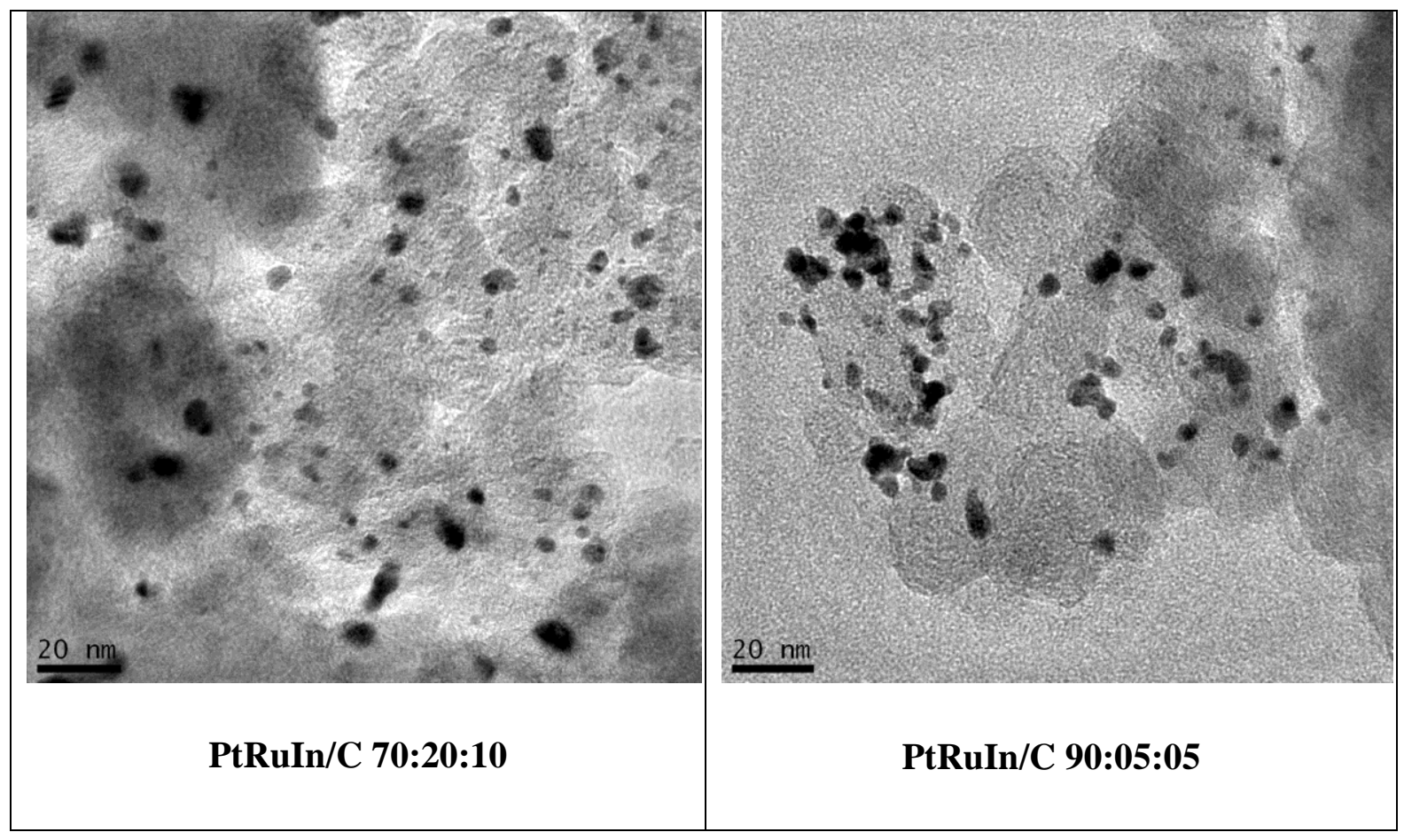

FIGURA 28 - Micrografias obtidas por MET dos catalisadores PtRuIn/C e suas diferentes composições.

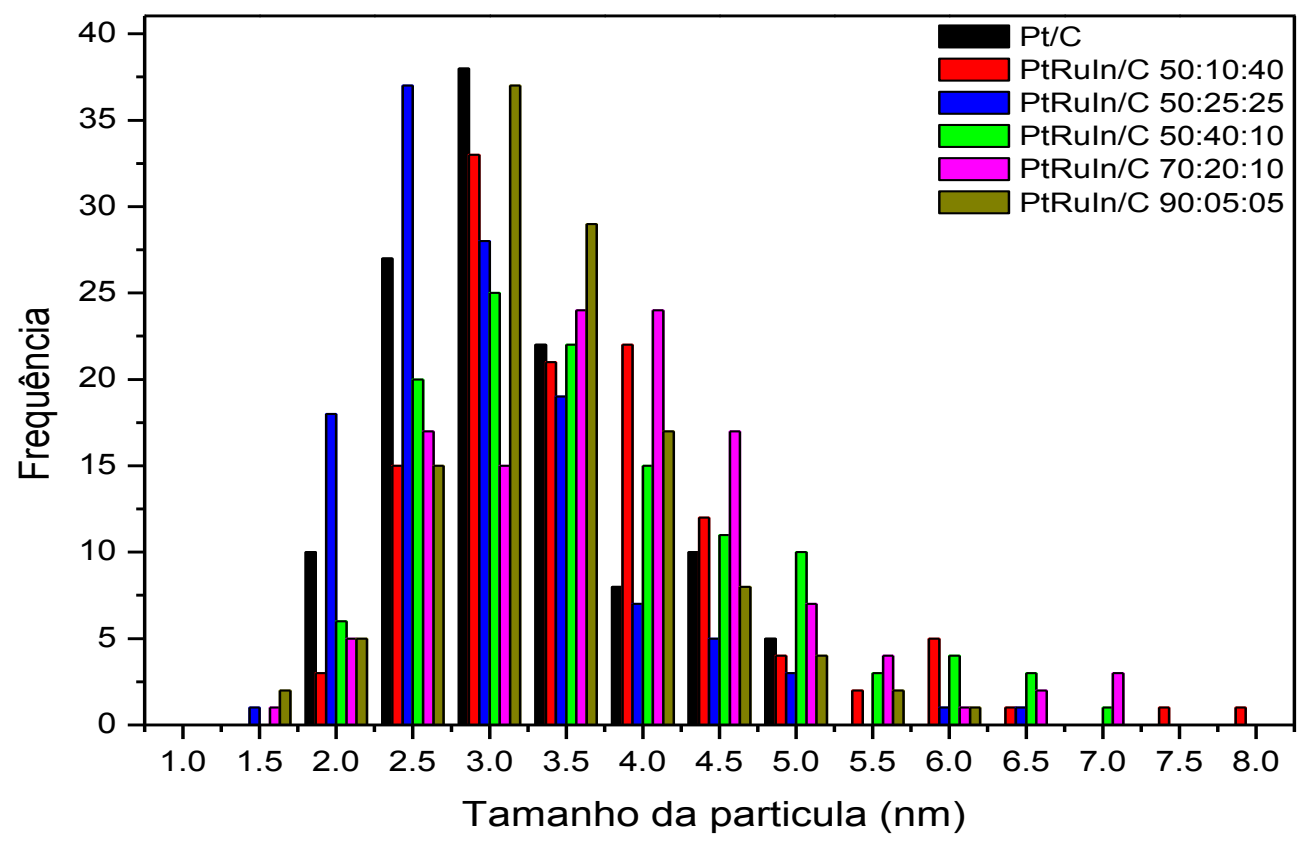

FIGURA 29 - Histograma da distribuição dos tamanhos das partículas dos eletrocatalisadores $\mathrm{Pt} / \mathrm{C}$ e PtRuIn/C e suas diferentes composições. 
A FIG. 28 mostra as micrografias obtidas pela técnica de Microscopia Eletrônica de Transmissão dos sistemas ternários PtRuIn/C 50:10:40, 50:25:25, 50:40:10, 70:20:10 e 90:05:05 e sua boa dispersão das nanopartículas sobre o suporte, os valores de diâmetros médio calculados se enquadraram na faixa de $3,42 \mathrm{~nm}, 2,74 \mathrm{~nm}, 3,41 \mathrm{~nm}, 3,50$ $\mathrm{nm}$ e 3,10 nm respectivamente, observado também pelo histograma de distribuição de tamanhos na FIG. 29. Alguns autores e colaboradores [10, 61, 65] estudaram binários dos metais que constituem os ternários em questão e obtiveram regiões de aglomeração nos sistemas catalíticos, o que não ocorreu mesmo em ternários com maior composição de Rutênio ou Índio, portanto, para as composições elementares nominais de partida e o método de redução aplicado a síntese é valida e eficiente já que as nanoparticulas estão distribuídas uniformemente sobre o carbono.

Na FIG. 30 são mostrados os voltamogramas cíclicos, com uma velocidade de varredura de $10 \mathrm{mV} . \mathrm{s}^{-1}$, dos eletrocatalisadores ternários PtRuIn/C preparados com as diferentes razões atômicas de metais, 50:10:40, 50:25:25, 50:40:10, 70:20:10 e 90:05:05 respectivamente, sintetizados pelo método de redução por Borohidreto de Sódio, em solução de $\mathrm{KOH} \mathrm{1,0} \mathrm{mol} \mathrm{L}{ }^{-1}$ a temperatura ambiente. A escolha das proporções de metais $\mathrm{Pt}: \mathrm{Ru}: \mathrm{In}$ para os catalisadores ternários foi feita com base no melhor comportamento dos sistemas $\mathrm{PtIn} / \mathrm{C}$ e $\mathrm{PtRu} / \mathrm{C}$ e as composições previamente estudadas. 


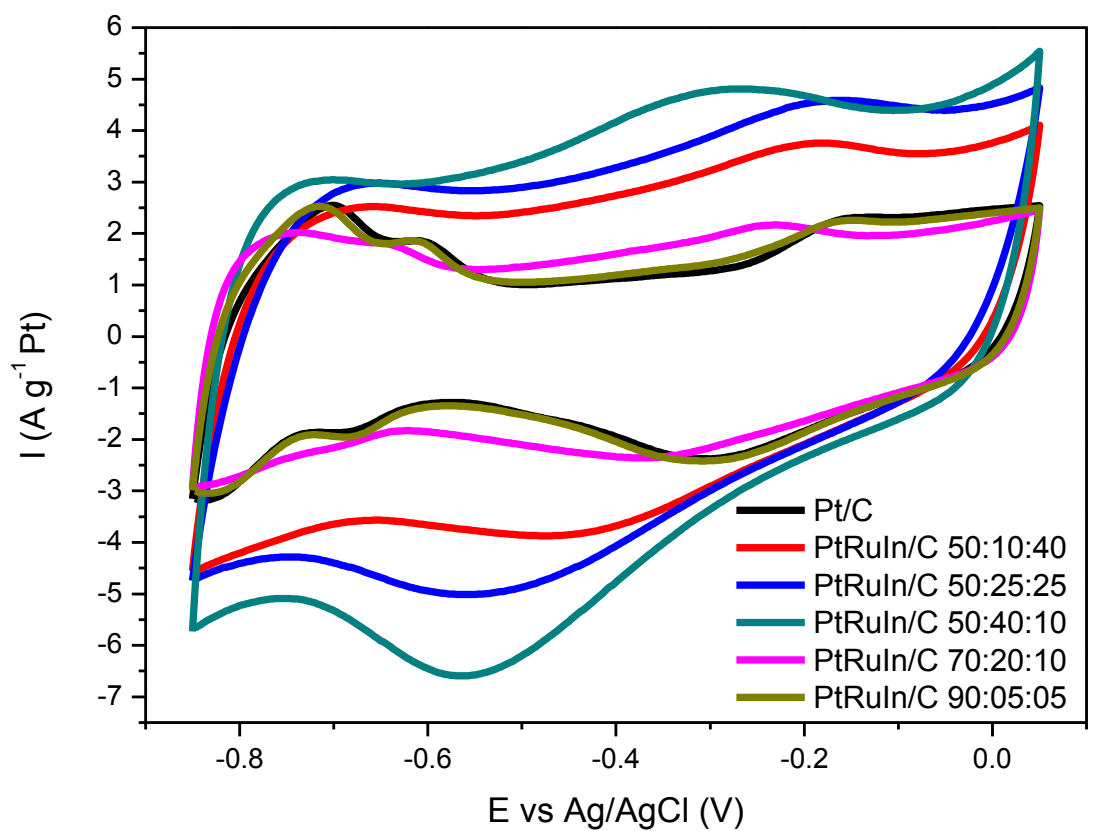

FIGURA 30 - Voltamogramas cíclicos com velocidade de varredura de $10 \mathrm{mV} \mathrm{s}-1$, dos eletrocatalisadores Pt/C, PtRuIn/C 50:10:40, PtRuIn/C 50:25:25, PtRuIn/C 50:40:10, PtRuIn/C 70:20:10 e PtRuIn/C 90:05:05, em solução de KOH 1,0 mol L-1 a temperatura ambiente.

Os voltamogramas dos ternários são mostrados na FIG. 30 onde todos os resultados foram normalizados por massa de Platina utilizada na composição dos mesmos. A região do voltamograma (de $-0,850 \mathrm{~V}$ a $-0,450 \mathrm{~V} v s$. $\mathrm{Ag} / \mathrm{AgCl}$ ) associada ao processo de adsorção/dessorção do Hidrogênio nos sítios catalíticos de Platina, com exceção da proporção 90:05:05 não está bem definida para os catalisadores ternários quando comparados ao sistema $\mathrm{Pt} / \mathrm{C}$, este comportamento já foi observado por outros autores que sintetizaram eletrocatalisadores pelo método de redução via Borohidreto de Sódio [59-60].

Os eletrocatalisadores 50:10:40, 50:25:25 e 50:40:10, apresentaram maior alargamento na região de dupla camada elétrica (na faixa de $-0,4$ a $-0,2 \mathrm{~V}$ vs $\mathrm{Ag} / \mathrm{AgCl}$ ) em comparação ao $\mathrm{Pt} / \mathrm{C}$, esse crescimento de valores de corrente pode ser atribuído à formação de espécies oxigenadas [49].

Na FIG.31 são ilustrados os resultados de voltametria cíclica para os eletrocatalisadores ternários sintetizados pelo método de redução via borohidreto de sódio na presença de 1,0 mol. $\mathrm{L}^{-1}$ de $\mathrm{KOH}+1,0$ mol.L ${ }^{-1}$ de metanol. 


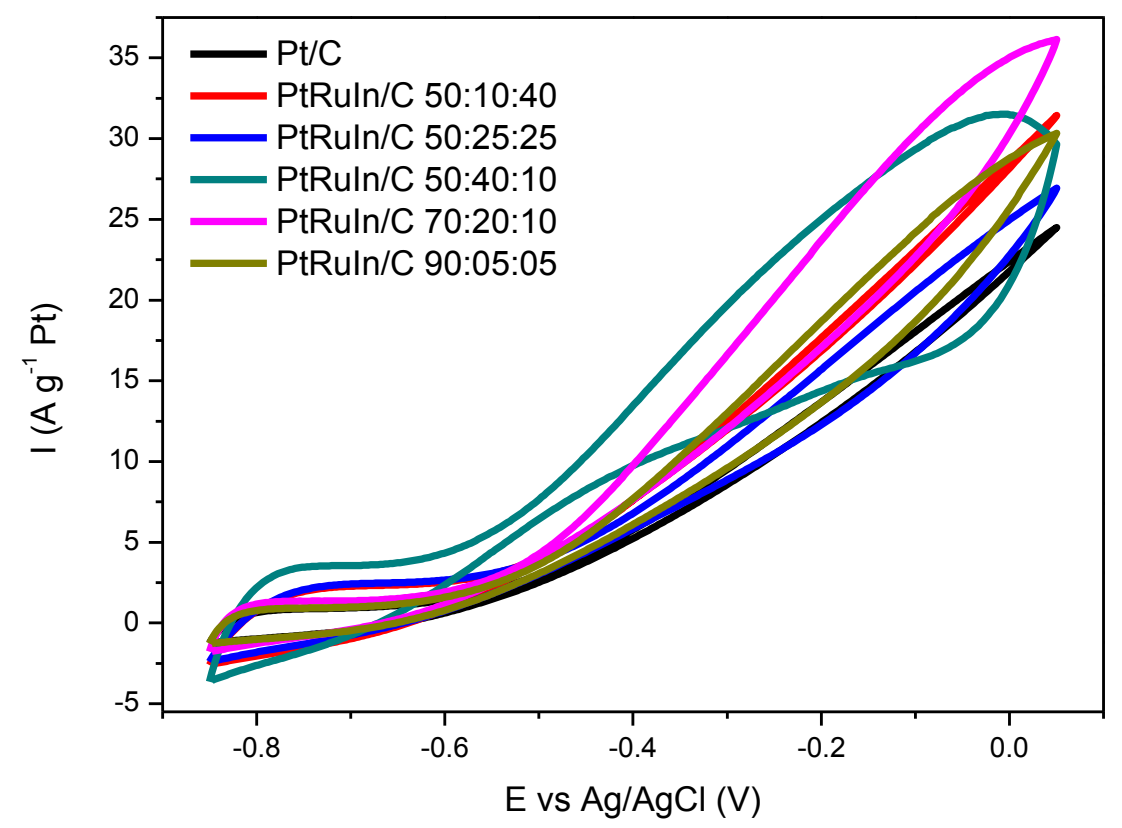

FIGURA 31 - Voltamogramas cíclicos com velocidade de varredura de $10 \mathrm{mV} \mathrm{s}^{-1}$, dos eletrocatalisadores Pt/C, PtRuIn/C 50:10:40, PtRuIn/C 50:25:25, PtRuIn/C 50:40:10, PtRuIn/C 70:20:10 e PtRuIn/C 90:05:05, em solução de KOH 1,0 mol L-1 e 1,0 mol L'-1 de metanol a temperatura ambiente.

A FIG.31 mostra a voltametria cíclica dos sistemas ternários sintetizados via Borohidreto de Sódio em presença de metanol, os gráficos obtidos foram normalizados pela quantidade de Platina que constitui cada sistema. Analisando o voltamograma, o sistema $\mathrm{Pt} / \mathrm{C}$ apresentou comportamento inferior quando comparado, o eletrocatalisador PtRuIn/C 50:40:10 apresentou-se como o mais efetivo, em que a eletro-oxidação do álcool se iniciou em potenciais menos positivos em relação aos demais. Esse empenho está atrelado a quantidade de Rutênio na composição do eletrocatalisador, conforme já foi mostrado por outros autores $[49,67]$ que sintetizaram PtRu/C 50:50 e obtiveram bons resultados. Como em tópicos anteriores foi verificado que o sistema In/C mostrou má atividade em meio alcalino, assume-se que a atividade eletrocatalítica aumentada, se deve a inserção de espécies de Índio à estrutura Pt-Ru formando uma liga ternária contribuindo para a oxidação de intermediários por meio do mecanismo eletrônico, já que o Rutênio contribui boa parte na oxidação do metanol por intermédio do mecanismo bifuncional [70]. 
Na FIG. 32 são ilustrados os resultados de cronoamperometria obtidos no potencial de $-400 \mathrm{mV}$ durante 30 minutos em solução de 1,0 mol.L ${ }^{-1}$ de metanol em 1,0 mol.L ${ }^{-1}$ de $\mathrm{KOH}$ a temperatura ambiente para $\mathrm{Pt} / \mathrm{C}$ e os eletrocatalisadores ternários sintetizados pelo método de redução via Borohidreto de Sódio.

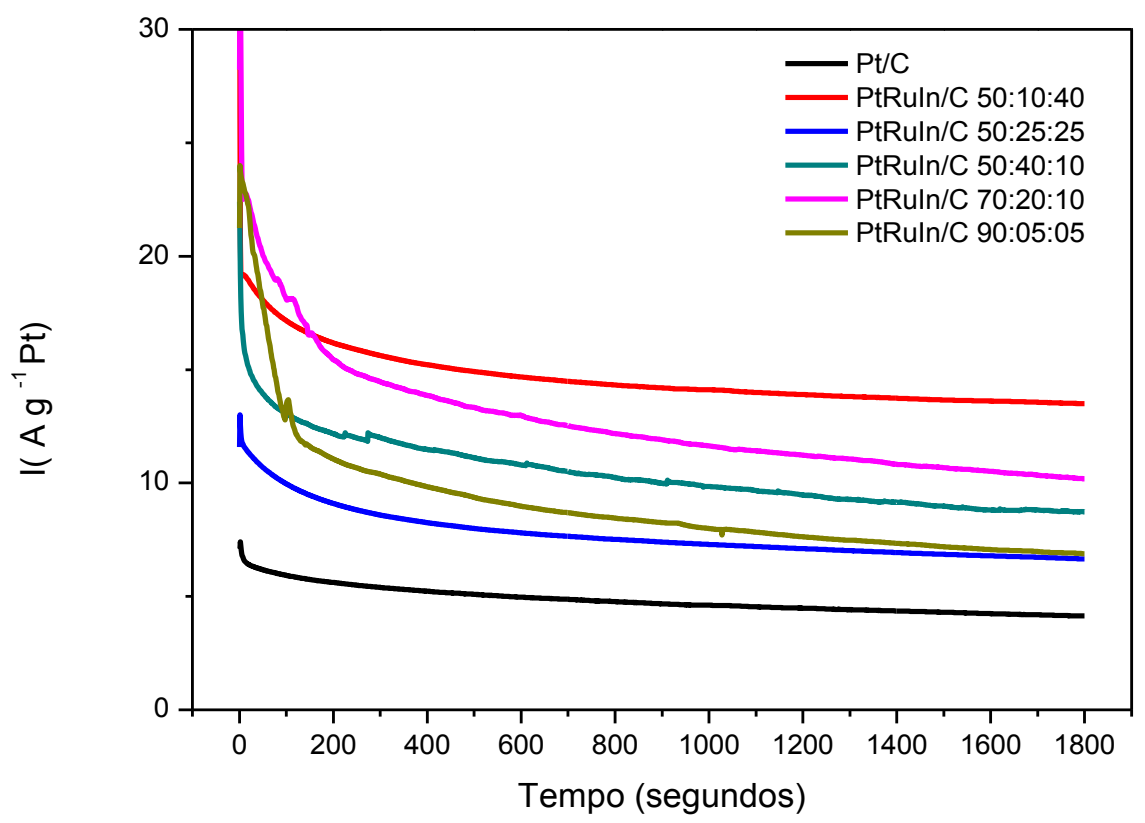

FIGURA 32 - Curva cronoamperométrica para os eletrocatalisadores de $\mathrm{Pt} / \mathrm{C}, \mathrm{PtRuIn} / \mathrm{C}$ 50:10:40, PtRuIn/C 50:25:25, PtRuIn/C 50:40:10, PtRuIn/C 70:20:10 e PtRuIn/C 90:05:05 obtidos na presença de 1,0 mol.L -1 de KOH e 1,0 mol.L -1 de metanol no potencial de $400 \mathrm{mV}$ durante 30 minutos.

Como já foi citado anteriormente [21], a queda acentuada de corrente na cronoamperometria, seguida por uma diminuição/estabilização da mesma durante o restante do tempo ocorre porque os sítios ativos estão inicialmente livres de moléculas de combustível adsorvidas e oxidadas. A taxa de adsorção de novas moléculas de metanol dependerá da disponibilidade de sítios catalíticos. Assim, a cinética da reação aumentará de acordo com a capacidade dos materiais para oxidarem intermediários (por exemplo $\mathrm{CO}$ ) responsáveis pelo envenenamento dos sítios catalíticos.

Para o teste em meio alcalino, os resultados de cronoamperometria mostraram que o eletrocatalisador PtRuIn/C 50:10:40 foi mais efetivo para oxidação do álcool com relação aos demais preparados, indicando que a estabilidade desse sistema pode estar atrelado a composição de Índio. Ottoni et al. estudou a eletro-oxidação de metanol em meio alcalino utilizando eletrocatalisadores $\mathrm{Pt} / \mathrm{C}, \mathrm{Pt} / \mathrm{ITO}$ e $\mathrm{Pt} / \mathrm{C}-\mathrm{In}_{2} \mathrm{O}_{3} \cdot \mathrm{SnO}_{2}$ (ITO) em 
diferentes proporções também sintetizados pelo método de redução via Borohidreto de Sódio e o resultado mais eficiente que obteve frente a oxidação do álcool na cronoamperometria foi por intermédio do sistema Pt/ITO, concluindo que, o ITO transfere espécies oxigenadas para intermediários adsorvidos regenerando os sítios de Platina para novos processos de adsorção [77]. Apesar da divergência de resultados, o ternário 50:40:10 obteve um bom desempenho catalítico, e possivelmente, a corrente de oxidação decaiu lentamente, devido a um recobrimento considerável dos sítios ativos de Platina pelo Rutênio, desfavorecendo a adsorção e desidrogenação do metanol.

Na FIG. 33 são ilustradas as curvas de polarização para $\mathrm{Pt} / \mathrm{C}, \mathrm{PtRuIn/C}$ 50:10:40, PtRuIn/C 50:25:25, PtRuIn/C 50:40:10, PtRuIn/C 70:20:10 e PtRuIn/C 90:05:05, fluxo $\sim 1 \mathrm{~mL}$ min-1 de solução de metanol $\left(2 \mathrm{~mol} \mathrm{~L}^{-1}\right)$, fluxo de $\mathrm{O}_{2}$ de $150 \mathrm{~mL}$ min-1, temperatura da célula: $80^{\circ} \mathrm{C}$ e temperatura de $\mathrm{H}_{2}, \mathrm{O}_{2}: 85^{\circ} \mathrm{C}$. 

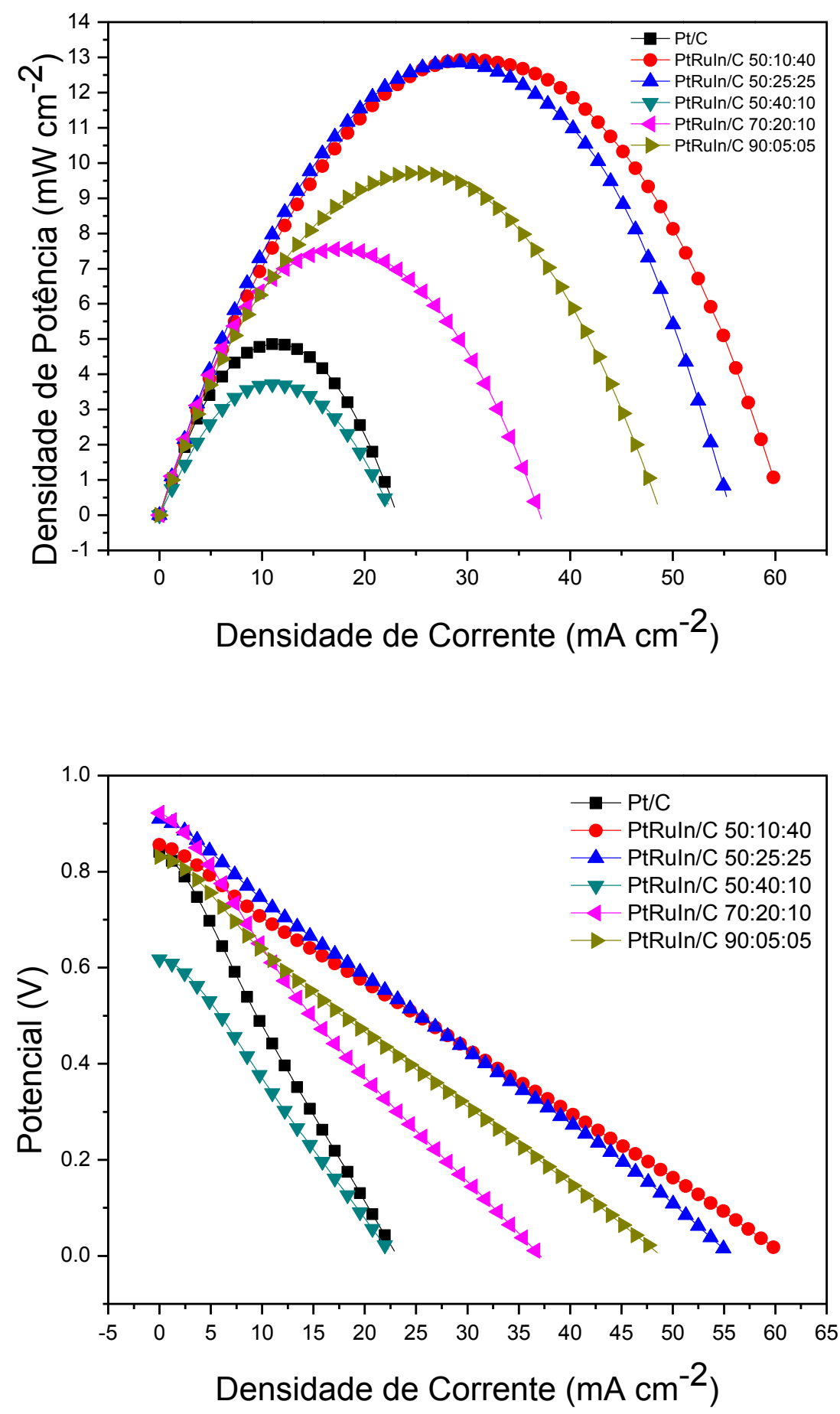

FIGURA 33 - Curvas de polarização para Pt/C, PtRuIn/C 50:10:40, PtRuIn/C 50:25:25, PtRuIn/C 50:40:10, PtRuIn/C 70:20:10 e PtRuIn/C 90:05:05, fluxo $\sim 1 \mathrm{~mL}$ min-1 de solução de metanol (2mol L-1), fluxo de $\mathrm{O} 2$ de $150 \mathrm{~mL}$ min-1, temperatura da célula: $80^{\circ} \mathrm{C}$ e temperatura de $\mathrm{H}_{2}, \mathrm{O}_{2}: 85^{\circ} \mathrm{C}$. 
Em todos os testes realizados em células a combustível diretamente alimentadas por metanol, os valores de potencial de circuito aberto obtidos $(0,830,0,855$, 0,909 e 0,921 V para as proporções 90:05:05, 50:10:40, 50:25:25 e 70:20:10, respectivamente), foram similares ao valor obtido para eletrocatalisador $\mathrm{Pt} / \mathrm{C}$ que foi de 0,841V, com exceção do sistema PtRuIn/C 50:40:10 que apresentou o valor de 0,617 V, fato que pode ser explicado pela dificuldade de prensagem e descolamento do MEA desta composição principalmente. Portanto, estudos voltados à confecção do MEA, são de extrema importância para a melhoria do funcionamento da célula, uma vez que é o componente central da PEMFC e as reações eletroquímicas do combustível, oxidante, transporte de reagentes e da água como produto dependem fortemente da sua estrutura e processo de fabricação [78-80]. Ao observar as curvas de polarização, nota-se que o eletrocatalisador que obteve a maior densidade de potência foi PtRuIn/C 50:10:40 resultando em $13 \mathrm{~mW} \mathrm{~cm}^{-2}$. Autores [61] que estudaram eletrocatalisadores $60 \% \mathrm{de} \mathrm{Pt} / \mathrm{C} \mathrm{e}$ $40 \%$ de $\mathrm{In}_{2} \mathrm{O}_{3}$ (mesma composição de Índio no eletrocatalisador de melhor desempenho), mostraram um aumento na performance quando a temperatura foi aumentada até $200^{\circ} \mathrm{C}$, o que consequentemente melhora a condutividade eletrolítica e aprimora a cinética das reações no eletrodo, parâmetro que provavelmente contribuiria para melhores resultados.

\subsection{COMPARAÇÃO DOS RESULTADOS OBTIDOS POR CARACTERIZAÇÃO ELETROQUÍMICA E TESTES PRÁTICOS DOS SISTEMAS BINÁRIOS E TERNÁRIOS}

Após os estudos e discussões a respeito do efeito dos elementos Índio e Rutênio em eletrocatalisadores binários, assim como o efeito de ambos nos ternários em presença de Platina, este tópico se dedica a comparar a eficiência de todos os eletrocatalisadores preparados. A seguir a TAB. 5 apresenta os valores de correntes obtidas com relação a estabilidade dos eletrocatalisadores pela cronoamperometria e as densidades de potência e corrente, tal como os valores de potencial de circuito aberto obtidos em testes práticos em células a combustível. 
TABELA 5 - Tabela de resultados comparativos de cronoamperometria e teste em célula de todos os eletrocatalisadores sintetizados via Borohidreto de Sódio.

\begin{tabular}{ccccc}
\hline \hline Eletrocatalisadores & I $\left(\mathbf{A ~ g ~}^{-1} \mathbf{P t}\right)$ & $\begin{array}{c}\text { Densidade de } \\
\text { Potência }(\mathbf{m W} \\
\left.\mathbf{c m}^{-2}\right)\end{array}$ & $\begin{array}{c}\text { Densidade de } \\
\text { Corrente }(\mathbf{m A} \\
\left.\mathbf{c m}^{-2}\right)\end{array}$ & $\begin{array}{c}\text { Potencial de } \\
\text { circuito } \\
\text { aberto }(\mathbf{V})\end{array}$ \\
\hline In/C & 0,22 & 0,2 & 2,04 & 0,07 \\
Pt/C & 4,13 & 4,98 & 23,55 & 0,84 \\
PtIn/C 50:50 & 10,75 & 11,85 & 57,74 & 0,86 \\
PtIn/C 90:10 & 13,16 & $\mathbf{1 6 , 8 3}$ & $\mathbf{8 4 , 2 8}$ & 0,86 \\
Ru/C & 6,82 & 11,30 & 46,81 & 0,90 \\
PtRu/C 50:50 & 0,01 & 1,70 & 1,83 & 0,50 \\
PtRu/C 70:30 & 12,85 & 9,09 & 59,76 & 0,78 \\
PtRu/C 90:10 & 10,07 & 5,32 & 34,80 & 0,69 \\
PtRuIn/C 50:10:40 & 13,49 & 7,24 & 36,65 & $\mathbf{0 , 9 4}$ \\
PtRuIn/C 50:25:25 & 6,65 & 13,04 & 61,02 & 0,85 \\
PtRuIn/C 50:40:10 & 8,72 & 13,01 & 55,92 & 0,90 \\
PtRuIn/C 70:20:10 & 10,18 & 3,98 & 22,81 & 0,61 \\
PtRuIn/C 90:05:05 & 6,88 & 7,76 & 37,54 & 0,92 \\
\hline \hline
\end{tabular}

Os estudos em meio alcalino expressaram que para os resultados obtidos por meio dos cronoamperogramas, o eletrocatalisador que mostrou maior estabilidade em que a diminuição da corrente decaiu lentamente em função do tempo, foi o PtRu/C 50:50. Neste caso, sugere-se que há maior quantidade de sítios ativos de Platina por área, o que facilita a adsorção do metanol. Já foi visto em literatura [69-70] que o Rutênio favorece a oxidação de intermediários e que a razão atômica entre os metais $\mathrm{Pt}$ e $\mathrm{Ru}$, são de extrema importância para se obter uma eficiência catalítica satisfatória. Além do que, como 
anteriormente foi comentado, a composição 50:50, tem mostrado eficiência para aplicação em células a combustível do tipo PEMFC [68], sendo aceita de forma bem difundida para a categoria DMFC [81-82].

Dado os resultados que constituem todas as curvas de polarização, o eletrocatalisador que apresentou melhor densidade de potência e de corrente, foi o PtIn/C 70:30, o que ressalta o papel importante do elemento Índio como um promotor significativo para facilitar a oxidação de $\mathrm{CO}$ a $\mathrm{CO}_{2}$ ou outros intermediários adsorvidos quanto para uma atividade eletrocatalítica superior em células tipo PEMFC-DMFC [10]. Manthiram et al. analisou Pt-ITO em uma proporção de 9:1 de $\operatorname{In}_{2} \mathrm{O}_{3} \cdot \mathrm{SnO}_{2}$ para eletrooxidação do metanol e concluiu alta estabilidade durante o ciclo potencial em seu estudo, a oxidação do $\mathrm{CO}$ adsorvido inicia em um potencial menor com Pt compatível com ITO do que com Pt suportado somente por Carbono, além de oferecer alta condutividade eletrônica [83], fatores que provavelmente influenciaram este estudo em questão.

A boa eficiência dos sistemas binários, nos sugeriram a principio que os eletrocatalisadores ternários fossem se comportar como os mais eficientes e aplicáveis as células a combustível, no entanto, mesmo a liga PtRu ainda sofre de um potencial excessivo significativo para a oxidação de combustíveis orgânicos e de intoxicação por compostos contendo enxofre (por exemplo), cada um dos quais resulta em perda de eficiência catalítica. Ademais, como em todas as ligas, o PtRu tem uma estrutura de superfície inerentemente mal definida, com seus locais de superfície ocupados por Pt ou $\mathrm{Ru}$ de forma aleatória e descontrolada, portanto, o uso de ligas à base de $\mathrm{Ru}$ no lugar da $\mathrm{Pt}$ pura apresenta um problema de estabilidade durante períodos prolongados de operação, particularmente sob uso não otimizado (especialmente a alta temperatura e densidade de corrente), a superfície da liga se esgota de Ru. Em alguns casos, Ru reporta-se de forma a facilitar a degradação da membrana que separa o ânodo e o cátodo e esta ruptura permite o cruzamento do combustível ao cátodo, o que diminui ainda mais a eficiência [82]. 


\section{CONCLUSÕES}

O método de redução via Borohidreto de Sódio se mostrou efetivo para a síntese de todos os eletrocatalisadores produzidos, supondo uma redução parcial de íons $\mathrm{In}^{+} / \mathrm{In}^{3+}$ deduzida pelos resultados obtidos para os sistemas binários PtIn/C. A maior parte dos eletrocatalisadores sintetizados, apresentou razões atômicas obtidas por EDX similares aos valores nominais, com exceção dos sistemas ternários, o que possivelmente pode ter sido promovido por recobrimento de Pt sob Ru e In ou a sobreposição das intensidades das bandas destes metais. Os difratogramas de Raios-X apresentaram para todos os sistemas eletrocatalítcos e suas diferentes proporções a estrutura CFC da Platina e a formação de liga para estes materiais. As micrografias demostraram para todos os eletrocatalisadores que as partículas de metal estavam homogeneamente distribuídas no suporte, com exceção do eletrocatalisador de PtIn/C 50:50, entretanto, o mesmo foi eletroquimicamente ativo para a oxidação do combustível em questão, o que evidencia que a atividade do sistema 50:50 está atrelada a superfície do mesmo e não somente a dispersão do metal no suporte.

Os estudos de caracterização eletroquímica mostraram que os sistemas PtIn/C 70:30, PtRu/C 50:50 e PtRuIn/C 50:10:40 para a eletro-oxidação de metanol foram os mais promissores, e que a atividade catalítica deles poderia estar relacionada com a combinação do mecanismo bifuncional (maior quantidade de óxidos produzidos na superfície) e ao efeito eletrônico.

Os resultados em célula alcalina unitária alimentadas diretamente por metanol demonstraram que as maiores densidades de corrente e potência foram obtidas pelos materiais que incluía boa proporção de Índio (PtIn/C 70:30 e PtRuIn/C 50:10:40) como metal auxiliar na oxidação do combustível e seus intermediários do que os eletrocatalisadores $\mathrm{Pt} / \mathrm{C}$, In/C e $\mathrm{Ru} / \mathrm{C}$ por exemplo. Os binários $\mathrm{PtRu} / \mathrm{C}$ apresentaram resultados divergentes para com os eletroquímicos em estudo. Este efeito pode estar associado a problemas de produção de MEA's e às baixas condutividades do material da membrana Nafion $^{\circledR}$, portanto o desenvolvimento de novas membranas aniônicas e ionômeros alcalinos é fortemente encorajado pelos resultados promissores dos experimentos eletroquímicos. Como trabalho de pesquisa adicional é necessário investigar os mecanismos da oxidação do metanol usando estes sistemas eletrocatalíticos e explorar a superfície destes materiais com a análise de XPS. 


\section{TRABALHOS PÚBLICADOS EM PERIÓDICOS INTERNACIONAIS}

Electrocatalysis (2016) 7:445-450 DOI 10.1007/s12678-016-03242

\section{Methanol Oxidation in Alkaline Medium Using PtIn/C Electrocatalysts}

M. C. L. Santos ${ }^{1}$ - C. A. Ottoni ${ }^{2}$ - R. F. B. de Souza ${ }^{3} \cdot$ S. G. da Silva ${ }^{1}$. M. H. M. T. Assumpção ${ }^{4}$ E. V. Spinacé ${ }^{1} \cdot$ A. O. Neto ${ }^{1}$

Published onl ine: 17 August 2016

(1) Spinger Science+Business Media New York 2016

Abstract $\mathrm{Pt} / \mathrm{C}$ and $\mathrm{PtIn} / \mathrm{C}$ with atomic ratios of $90: 10,70: 30$, and 50:50 were investigated for methanol electro-oxidation in alkaline media by using cyclic voltammetry (CV), chronoamperometry (CA), and direct methanol alkal ine fuel cell (DMAFC). All electrocatalysts were synthesized using sodium borohydride method with $20 \mathrm{wt} \%$ of metals loading on carbon. X-ray diffraction (XRD) analysis revealed that bimetallic PtIn had faced centered cubic structure and, also, confirmed alloy formation for PtIn/C nanoparticles. Transmission electron micrographs showed metal nanoparticles with average particle size between 3.0 and $5.0 \mathrm{~nm}$; however, the particle size increases when the In content was increased in PtIn/C. In the CV experiments, the onset potential of methanol electro-oxidation shifted to lower values as the indium content increased. Chronoamperometry experiments and direct methanol alkaline fuel cell suggested PtIn/C $(70: 30)$ as the most promising material for methanol electrooxidation: this result could be explained by the presence of $\mathrm{Pt}$ and In in close contact (electronic effect) as the occurrence of
Keywords Methanol oxidation - PtIn electrocatalysts Alkaline fuel cell

\section{Introduction}

Fuel cells are one of the most promising energy sources for application in portable devices, vehicles, and stationary devices [1]. In this context, polymer electrolyte mambrane fuel cells (PEMFC) have attracted a great deal of attention due to series of highly advantageous features, such as low operating temperature and sustained operation at high current density $[2-4]$. In the development of low temperature fuel cells, it is usually utilized organic molecules, such as methanol, thanol and formic acid, because they do not bring problems as to distribution and storage when compared to hydrogen gas [5] Methanol is considered a promising system for energy conversion due to its high energy density $\left(702.32 \mathrm{~kJ} \mathrm{~mol}^{-1}\right)$ and it is 
International Journal of ELECTROCHEMICAL

SCIENCE

www.electrochemsci.org

\section{Preparation of $\mathrm{PtRu} / \mathrm{C}$ Electrocatalysts by Borohydride Reduction for Methanol Oxidation in Acidic and Alkaline Medium}

Monique Carolina Lima dos Santos, Rita Maria Dutra, Vilmaria Aparecida Ribeiro, Estevam Vitório Spinacé and Almir Oliveira Neto ${ }^{*}$

Instituto de Pesquisas Energéticas e Nucleares - IPEN/CNEN-SP, Av. Prof. Lineu Prestes, 2422 Cidade Universitária - CEP 05508-900 São Paulo, SP, Brazil

E-mail: aolivei@ipen.br

Received: 5 January 2017 / Accepted: 11 March 2017 / Published: 12 April 2017

$\mathrm{PtRu} / \mathrm{C}$ electrocatalysts were performed according to the borohydride reduction method and
characterized by X-ray diffraction $(\mathrm{XRD})$, energy dispersive analysis (EDX), transmission electron
microscopy, cyclic voltammetry $(\mathrm{CV})$ and polarization curves in alkaline and acidic medium. The X-
ray diffraction $(\mathrm{XRD})$ of $\mathrm{PtRu} / \mathrm{C}$ showed $\mathrm{Pt}$ peaks attributed to the face-centered cubic (fcc) structure
and a shift in $\mathrm{Pt}(\mathrm{fcc})$ peaks indicated that Ru was incorporated into Pt lattice. TEM results showed
mean particles sizes in the range of $2.0-4.0 \mathrm{~nm}$ for all electrocatalysts prepared: therefore, the
borohydride reduction process was considered effective for the preparation of PtRu/C electrocatalysts
with a different atomic ratio. The activity for the methanol oxidation in acidic and alkaline media was
investigated at room temperature, by cyclic voltammetry and chronoamperometry. Cyclic voltammetry
and chronoamperometry studies showed that $\mathrm{PtRu} / \mathrm{C}(50: 50)$ had superior performance for methanol
oxidation, compared with other electrocatalysts prepared considering acidic and alkaline studies. The 


\section{TRABALHOS FUTUROS}

O objetivo geral do projeto de pesquisa futuro do Doutorado é desenvolver eletrocatalisadores do tipo Metal de Transição-Heteroátomo/C ativos e estáveis para as reações de redução de nitrito/nitrato e de oxigênio, bem como caracterizar seus sítios ativos no sentido de otimiza-los para as citadas reações focando as peculiaridades de cada sistema eletroquímico assim como aplicações ambientais e energéticas.

Como pontos específicos da proposta futura destacam-se:

Sintetizar eletrocatalisadores baseados em nanoestruturas de carbono dopadas com heteroátomos (N, S e P) coordenados a átomos de metais de transição (Fe, Mn e Co), tendo como inspiração inicial um método de síntese publicado na literatura;

Desenvolver métodos de síntese originais;

Quantificar e determinar os sítios ativos nos materiais ex-situ e in-situ, p. ex. pelo método de stripping de nitrito, somado a métodos in-situ originais que serão objetivados;

Estudar a reação de redução de nitrito, nitrato, óxido nítrico e oxigênio em diferentes valores de $\mathrm{pH}$ (eletrólitos);

Estudar o potencial catalítico dos materiais para tratamento de águas residuais reais;

Empregar estes eletrocatalisadores como cátodo de sistemas eletroquímicos como a célula a combustível a metanol direto. 


\section{REFERÊNCIAS BIBLIOGRÁFICAS}

[1] LARMINIE, J.; DICKS, A. Fuel cell systems explained. $2^{\mathrm{a}}$ ed. Chichester: John Wiley., p. 418, 2003.

[2] WENDT, H.; GOTZ, M.; LINARD, M. Tecnologia de células à combustível. Química Nova, v. 23, n. 4, p. 538-546, 2000.

[3] TICIANELli, E. A.; GONZALEZ, E. R. Células a combustível: uma alternativa promissora para geração de eletricidade. Química Nova, v. 12, n. 3, p. 268-271, 1989.

[4] SORENSEN, B. Renewable Energy: Its physics, engineering, use, environmental impacts, economy and planning aspects. $3^{\text {a }}$ ed. Elsevier Academic Press, Roskilde, Denmark, 2004.

[5] ANDÚJAR, J.M.; SEGURA, F. Fuel cells: History and uptading. A walk along two centuries. Renewable and Sustainable Energy Reviews, v. 13, n. 9, p. 2309-2322, 2009.

[6] KREWER, U.; VIDAKOVIC-KOCH, T.; RIHKO-STRUCKMANN, L. Electrochemical oxidation of carbon-containing fuels and their dynamics in lowtemperature fuel cells. ChemPhysChem, v. 12, n.14, p. 2518-2544, 2011.

[7] ZHAO, Y.; YANG, X.; TIAN, J.; WANG, F.; ZHAN, L. Methanol electro-oxidation on Ni@Pd core-shell nanoparticles supported on multi-walled carbon nanotubes in alkaline media. International Journal of Hydrogen Energy, v. 35, p. 3249-3257, 2010.

[8] ZHU, M.; SUN, G.; XIN, Q. Effect of alloying degree in PtSn catalyst on the catalytic behavior for ethanol electro-oxidation. Electrochimica Acta, v. 54 , n. 5, p. 1511-1518, 2009.

[9] BUZZO, G. S.; ORLANDI, M.J.B.; TEIXEIRA-NETO, E.; HOMEM-DE-MELLO, P.; LOPES, A.C.G.; FRANCO, E. J.; SUFFREDINI, H. B. Effects of catalyst load in Pt and $\mathrm{Pb}$-based catalysts using formic acid oxidation as a model. Journal of Power Sources, v. 199, p. 75-84, 2012.

[10] VEIZAGA, N. S., PAGANIN, A. V., ROCHA, T. R., SCELZAA, O. A, DE MIGUEL, S. R., GONZALEZ, E. R. Development of PtGe and PtIn anodic catalysts supported on carbonaceous materials for DMFC. International Journal of Hydrogen Energy. v.39, n. 16, p. 8728-8737, 2014.

[11] GARCHE, J.; JÖRISSEN, L. Applications of Fuel Cell Technology: Status and Perspectives. The Electrochemical Society, Interface Summer, v. 24, p. 39-43, 2015.

[12] WILlians, M. C. Fuel Cell Handbook. $7^{\text {a }}$ ed., Department of Energy: West Virginia, EG\&G Technical Services, U.S.A; 2004. 
[13] HAILE, S. M. Fuel cell materials and components. Acta Materialia, v. 51, p. 59816000, 2003.

[14] HERNANDEZ, K. E. G.; Síntese, caracterização e estudo do desempenho de catalisadores de PtRuMo/C tolerantes a Co. Dissertação (Mestrado em Físico-Química) Instituto de Química de São Carlos, Universidade de São Paulo, São Carlos, 2014.

[15] LITSTER, S.; MCLEAN, G. PEM fuel cell electrodes. Journal of Power Sources, v. 130., p. 61-76, 2004.

[16] WENDT, H.; SPINACÉ, E. V.; NETO, A. O.; LINARDI, M. Electrocatalysis and electrocatalysts for low temperature fuel cells: fundamentals, state of the art, research and development. Química Nova, v. 28, n. 6, p. 1066-1075, 2005.

[17] LINARDI, M. Introdução à ciência e tecnologia de células a combustível. São Paulo, SP: Artliber, 2010.

[18] SCOTT, K.; YU, E.; VLACHOGIANNOPOULOS, G.; SHIVARE, M.; DUTEANU, N. Performance of a direct methanol alkaline membrane fuel cell. Journal of Power Sources, v. 175, p. 452-457, 2008.

[19] RAYMENT, C.; SHERWIN, S.; Introduction to Fuel Cell Technology. $1^{\mathrm{a}}$ ed. Department of Aerospace and Mechanical Engineering University of Notre Dame. Notre Dame, U.S.A., 2003.

[20] ZHANG, X.W. Advances in Fuel Cells. Research Signpost, Kerala, India, p. 181198. 2005.

[21] PIASENTIN, R. M. Estudo da eletro-oxidação do etanol utilizando eletrocatalisadores $\mathrm{PtPd} / \mathrm{C}+$ ato e $\mathrm{PtPdSn} / \mathrm{C}+$ ato preparados via redução por Borohidreto de Sódio. Tese (Doutorado em Ciências-Tecnologia Nuclear) - Instituto de Pesquisas Energéticas $\boldsymbol{e}$ Nucleares, Universidade de São Paulo, São Paulo, 2013.

[22] MCLEAN, G. F.; NIET, T.; PRINCE-RICHARD, S.; DJILALI, N. An assessment of alkaline fuel cell technology. International Journal of Hydrogen Energy, v.27, p.507526, 2002.

[23] KIEFER, J.; BRACK, H-P.; HUSLAGE, J.; BUCHI, F. N.; TSAKADA, A.; GEIGER, F.; SCHERER, G. G. Radiation grafting: A versatile membrane preparation tool for fuel cell applications. Proceedings of the European Fuel Cell Forum Portable Fuel Cells Conference, Lucerne, p. 227-235, 1999.

[24] FERRIN, P.; UDAYKUMAR, N.; GREELEY, J.; MAVRIKAKIS, M.; ROSSMEIL, J. Reactivity descriptors for direct methanol fuel cell anode catalysts. Surface Science, v. 602. p. 3424-3431, 2008. 
[25] DONER, A.; KARDAS, G. A novel, effective and low cost electrocatalyst for direct methanol fuel cells applications. International Journal of Hydrogen Energy, v.40, n.14, p. 4840-4849, 2015.

[26] NEUROCK, M.; JANIKB, M.; WIECKOWSKIC, A. A first principles comparison of the mechanism and site requirements for the electrocatalytic oxidation of methanol and formic acid over Pt. Faraday Discuss, v. 140, p. 363-378, 2008.

[27] SAMJESKE, G.; MIKI, A.; YE, S.; YAMAKATA, A.; MUKOUYAMA, Y.; OKAMOTO, H.; OSAWA, M. Potential oscillations in galvanostatic electrooxidation of formic acid on platinum: A time-resolved surface-enhanced infrared study. The Journal of Physical Chemistry B, v.109, p. 23509-23516, 2005.

[28] CUESTA, A.; CABELlO. G.; OSAWA, M.; GUTIERREZ, C. Mechanism of the electrocatalytic oxidation of formic acid on metals. ACS Catalysis, v.2, p. 728-738, 2012.

[29] CUESTA, A.; CABELLO. G.; GUTIERREZ, C.; OSAWA, M. Adsorbed formate: the key intermediate in the oxidation of formic acid on platinum electrodes. Physical Chemistry Chemical Physics, v. 13, p. 20091-20095, 2011.

[30] KORZENIEWSKI, C.; CHILDERS, C. L. Formaldehyde yields from methanol electrochemical oxidation on platinum. The Journal of Physical Chemistry B, v. 102, n.3, p.489-492, 1998.

[31] CHILDERS, C. L., HUANG, H. L.; KORZENIEWSKI, C. Formaldehyde yields from methanol electrochemical oxidation on carbon-supported platinum catalysts. Langmuir, v.15, n.3, p. 786-789, 1999.

[32] ISLAM, M.; BASNAYAKE, R.; KORZENIEWSKI, C. A study of formaldehyde formation during methanol oxidation over PtRu bulk alloys and nanometer scale catalyst. Journal of Electroanalytical Chemistry, v. 599, n.1, p. 31-40, 2007.

[33] CHEN, Y. X.; YE, S.; HEINEN, M.; JUSYS, Z.; OSAWA, M.; BEHM, R. J. Application of in-situ attenuated total reflection-Fourier transform infrared spectroscopy for the understanding of complex reaction mechanism and kinetics: Formic acid oxidation on a Pt film electrode at elevated temperatures. The Journal of Physical Chemistry B, v. 110, n.19, p. 9534-9544, 2006.

[34] MIKI, A.; YE, S.; SENZAKI, T.; OSAWA, M. Surface-enhanced infrared study of catalytic electrooxidation of formaldehyde, methyl formate, and dimethoxymethane on platinum electrodes in acidic solution. Journal of Electroanalytical Chemistry, v. 563, n.1, p. 23-31, 2004.

[35] SAMJESKE, G.; MIKI, A.; YE, S.; OSAWA, M. Mechanistic study of electrocatalytic oxidation of formic acid at platinum in acidic solution by time-resolved surface-enhanced infrared absorption spectroscopy. The Journal of Physical Chemistry B, v. 110, n.33, p.16559-16566, 2006. 
[36] HOUSMANS, T. H. M.; WONDERS, A. H.; KOPER, M. T. M. Structure sensitivity of methanol electrooxidation pathways on platinum: An on-line electrochemical mass spectrometry study. Journal of Electroanalytical Chemistry, v. 110, n.20, p. 1002110031, 2006.

[37] LAI, S. C. S.; LEBEDEVA, N. P.; HOUSMANS, T. H. M.; KOPER M. T. M. Mechanisms of carbon monoxide and methanol oxidation at single-crystal electrodes. Topics in Catalysis, v.46, p.320-333, 2007.

[38] KORDESCH, K.; SIMADER, G. Fuel Cells and Their Applications. $1^{\mathrm{a}}$ ed. New York: VCH Publishers, p. 40-42, 1996.

[39] IWASITA, T. Handbook of Fuel Cells: Technology and Applications. New York, N.Y.: John Wiley \& Sons, v.2, p. 603-624, 2003.

[40] WATANABE, M.; MOTOO, S. Electrocatalysis by ad-atoms: Part I. Enhancement of the oxidation of methanol on platinum and palladium by gold ad-atoms. Journal of Electroanalytical Chemistry and Interfacial Electrochemistry, v. 60, n.3, p.259-266, 1975.

[41] WATANABE, M.; MOTOO, S. Electrocatalysis by ad-atoms: Part III. Enhancement of the oxidation of carbon monoxide on platinum by ruthenium ad-atoms. Journal of Electroanalytical Chemistry and Interfacial Electrochemistry, v. 60, n.3, p. 275-283, 1975.

[42] FREITAS, K. S. Eletrocatalisadores de ligas de platina dispersos em substratos de óxidos para a reação de oxidação de hidrogênio puro e na presença de CO. Tese (Doutorado em Físico-Química) - Instituto de Química de São Carlos, Universidade de São Paulo, São Carlos, 2009.

[43] CORTINOVIS, G. F. Desenvolvimento da obtenção do etanoato de 2-butoxietila a partir de etanoato de 2-etoxietila e 2-butoxietanol. Tese (Doutorado em Engenharia Química) - Instituto de Engenharia Politécnica, Universidade de São Paulo, São Paulo, 2012.

[44] HOUGEN, O. A.; WATSON, K. M. Solid Catalysts and Reaction Rates-General Principles. Industrial and Engineering Chemistry, v. 35, p. 529-541, 1943.

[45] LEE, M. J.; KANG, J. S.; KANG, Y. S.; CHUNG; D. Y.; SHIN, H.; AHN; C-Y.; PARK, S.; KIM, M-J.; KIM, S.; LEE, K-S.; SUNG, Y-E. Understanding the Bifunctional Effect for Removal of CO Poisoning: Blend of a Platinum Nanocatalyst and Hydrous Ruthenium Oxide as a Model System. ACS Catalysis, v. 6, p.2398-2407, 2016.

[46] HAMMER, B.; MORIKAWA, Y.; NORSKOV, J. K. CO Chemisorption at Metal Surfaces and Overlayers. Physical Review Letters, v. 76, p. 2141-2144, 1996. 
[47] MCBREEN, J.; MUKERJEE, S. In Situ X-Ray Absorption Studies of a Pt-Ru Electrocatalyst. Journal of the Electrochemical Society, v. 142, n.10, p.3399-3404, 1995.

[48] CAMARA, G. A.; GIZ, M. J.; PAGANIN, V. A.; TICIANELlI, E. A. Correlation of electrochemical and physical properties of PtRu alloy electrocatalysts for PEM fuel cells. Journal of Electroanalytical Chemistry, v. 537, n. 1-2, p. 21-29, 2002.

[49] BRANDALISE, M. Preparação e caracterização de eletrocatalisadores PtRu/C, $\mathrm{PtBi} / \mathrm{C}, \mathrm{PtRuBi} / \mathrm{C}$ para eletro-oxidação direta de etanol em células a combustível tipo PEM utilizando a metodologia da redução via Borohidreto de Sódio. Dissertação (Mestre em Ciências-Tecnologia nuclear) - Instituto de Pesquisas Energéticas e Nucleares, Universidade de São Paulo, São Paulo, 2010.

[50] HYUN, M.-S.; KIM, S.-K.; LEE, B.; PECK, D.; SHUL, Y.; JUNG, D. Effect of $\mathrm{NaBH}_{4}$ concentration on the characteristics of PtRu/C catalyst for the anode of DMFC prepared by the impregnation method. Catalysis Today, v. 132, n. 1-4, p. 138-145, 2008.

[51] KIRKLAND, A. I.; HUTCHISON, J. L.; Nanocharacterization. $1^{\text {a }}$ ed. Cambridge: RSC Publishing, 2007.

[52] WU, J.; YUAN, X.Z.; WANG, H.; BLANCO, M.; MARTIN, J.J.; ZHANG, J. Diagnostic tools in PEM fuel cell research: Part I Electrochemical techniques. International Journal of Hydrogen Energy, v. 33, n. 6, p. 1735-1746, 2008.

[53] YU, E. H.; SCOTT, K.; REEVE, R. W. A study of the anodic oxidation of methanol on Pt in alkaline solutions. Journal of Electroanalytical Chemistry, v.547, p.19. 2003.

[54] SKOOG, D.A.; HOLLER, F.J.; NIEMAN, T.A. Princípios de Análise Instrumental. 5 ${ }^{\text {a }}$ ed. Porto Alegre, Bookman, 2002.

[55] CAO, A.; XU, C.; LIANG, J.; WU, D.; WEI, B. Adsorption of fluoride from water by amorphous alumina supported on carbon nanotubes. Chemical Physics Letters, v.350, p..412-416, 2001.

[56] LI, W.; LIANG, C.; ZHOU, W.; QIU, J.; ZHOU, Z.; SUN, G.; XIN, Q. Preparation and characterization of multiwalled carbon nanotube-supported platinum for cathode catalysts of direct methanol fuel cells. The Journal of Physical Chemistry, v.107, n.26, p.6292-6299, 2003.

[57] HARRIS, I.R.; NORMAN, M.; BRYANT, A. W.; A study of some palladiumindium, platinum-indium and platinum-tin alloys. Journal of the less-common metals, v.16 p. 427-440., 1968.

[58] PASTIA. A. I., NEMANJA M., GAVRILOVA., et al., Oxygen reduction reaction of Pt-In alloy: Combined theoretical and experimental investigations. Electrochimica Acta, v.114, p. 706-712, 2013. 
[59] SALGADO, J. R. C. Desenvolvimento de catalisadores de Pt-Co/C para reação de redução de oxigênio em célula $s$ a combustível de membrana de troca protônicas. Tese (Doutorado em ciências) - Instituto de Química de São Carlos, Universidade de São Paulo, São Carlos, 2005.

[60] DA SILVA, S.G.; SILVA, J.C.M.; BUZZO, G.S.; DE SOUZA, R.F.B.; SPINACÉ, E.V.; NETO, A.O.; ASSUMPÇÃO, M.H.M.T. Electrochemical and fuel cell evaluation of $\mathrm{PtAu} / \mathrm{C}$ electrocatalysts for etanol electro-oxidation in alcaline media. International Journal of Hydrogen Energy, v. 39, n. 19, p. 10121-10127, 2014.

[61] PARRONDO, J.; SANTHANAM, R.; MIJANGOS, F.; RAMBABU, B. Electrocatalytic performance of In2O3-supported Pt/C nanoparticles for ethanol electrooxidation in direct ethanol fuel cells. International Journal of Electrochemical Science, v. 5, p.1342-1354, 2010.

[62] GE, X.; SUMBOJA, A.; WUU, D.; AN, T.; LI, B.; GOH, F. W. T.; HOR, T. S. A.; ZONG, Y.; LIU, Z. Oxygen Reduction in Alkaline Media: From Mechanisms to Recent Advances of Catalysts, ACS Catalysis, v. 5, p. 4643-4667, 2015.

[63] CHU, D., WANG. J., WANG. S., ZHA. L., HE. J., HOU. Y., YAN. Y., LIN, H., TIAN. Z. High activity of Pd- $\mathrm{In}_{2} \mathrm{O}_{3} / \mathrm{CNT}$ electrocatalyst for electro-oxidation of ethanol. Catalysis communications, v. 10, n. 6, p.955-958, 2009.

[64] SUDA, Y.; SHIMIZU, Y.; OZAKI, M; TANOUE, H.; TAKIKAWA, H.; UE, H.; SHIMIZU, K.; UMEDA, Y. Electrochemical properties of fuel cell catalysts loaded on carbon nanomaterials with different geometries. Materials Today Communications, v.3, p. 96-103, 2015.

[65] HYUN, M.S.; KIM, S.K.; LEE B., PECK, D.; SHUL Y.; JUNG D. "Effect of $\mathrm{NaBH}_{4}$ concentration on the characteristics of $\mathrm{PtRu} / \mathrm{C}$ catalyst for the anode of DMFC prepared by the impregnation method", Catalysis Today, v. 132, p.138- 145, 2008.

[66] BRANDALISE, M.; VERJULIO-SILVA, R.W.R.; TUSI, M.M.; CORREA, O. V.; FARIAS, L.A.; LINARDI, M.; SPINACÉ, E.V.; NETO, A.O. Electrooxidation of ethanol using $\mathrm{PtRuBi} / \mathrm{C}$ electrocatalyst prepared by borohydride reduction. Ionics, v. 15, n.6, p. 743-747, 2005.

[67] SANTASALO, A. A.; TUOMI, S. JALKANEN, K.; KONTTURI, K.; KALLIO, T. The correlation of electrochemical and fuel cell results for alcohol oxidation in acidic and alkaline media. Electrochimica Acta, v. 87, p. 730- 738, 2013.

[68] CHOI, J. H.; PARK, K.; PARK, I.; NAM, W.; SUNG, Y. Methanol electro-oxidation and direct methanol fuel cell using $\mathrm{Pt} / \mathrm{Rh}$ and $\mathrm{Pt} / \mathrm{Ru} / \mathrm{Rh}$ alloy catalysts. Electrochimica Acta, v. 50, p. 787-790, 2004. 
[69] TAN, C.; SA, J.; CAI, F.; JIANG, B.; YANG, G.; WANG, B.; GAO, J.; CHEN, H.; QIN, X. Bimetallic PtRu Nanoparticles Supported on Functionalized Multiwall Carbon Nanotubes as High Performance Electrocatalyst for Direct Methanol Fuel Cells. NANO: Brief Reports and Reviews, v. 11, p. 1650022-1-1650022-8, 2016.

[70] LU, C.; RICE, C.; MASEL, R. I.; BABU, P. K.; WASZCZUK, P.; KIM, H. S.; OLDFIELD, E.; WIECKOWSKI, A. UHV, Electrochemical NMR, and Electrochemical Studies of Platinum/Ruthenium Fuel Cell Catalysts. The Journal of Physical Chemistry $\boldsymbol{B}$, v. 106, p. 9581-9589, 2002.

[71] VERJULIO-SILVA, R.W.R. Preparação e caracterização de eletrocatalisadores $\mathrm{PtRu} / \mathrm{C}$ e PtSn/C via redução química por ácido cítrico para oxidação direta de álcoois em células a combustível tipo PEM. Dissertação (Mestre em ciências-área de tecnologia nuclear) - Instituto de Pesquisas energéticas e nucleares, Universidade de São Paulo, São Paulo, 2008.

[72] DIAS, R. R., Preparação e caracterização de eletrocatalisadores PtRu/C, PtSn/C, $\mathrm{PtRh} / \mathrm{C}, \mathrm{PtRuRh} / \mathrm{C}$ e $\mathrm{PtSnRh} / \mathrm{C}$ para oxidação direta de álcoois em células a combustível tipo PEM utilizando a metodologia de redução por álcool. Dissertação (Mestre em ciências-área de tecnologia nuclear) - Instituto de Pesquisas energéticas e nucleares, Universidade de São Paulo, São Paulo, 2009.

[73] YANG, C.; WANG, S.; JIANG, L.; HU, J.; MA, W.; SUN, G. 1,2Dimethylimidazolium-functionalized cross-linked alkaline anion exchange membranes for alkaline direct methanol fuel cells. International Journal of Hydrogen Energy, v. 40, p. 2363-2370, 2015.

[74] JARUPUK THEPKAEW, J.; THERDTHIANWONG, S.; THERDTHIANWONG, A.; KUCERNAK, A.; WONGYAO, N. Promotional roles of Ru and Sn in mesoporous PtRu and PtRuSn catalysts toward ethanol electrooxidation. International Journal of Hydrogen Energy, v. 38, p. 9454-9463, 2013.

[75] NEIVA, A. C.; DRON, J. Caracterização de bens culturais por espectroscopia de fluorescência de Raios-X. Centro de Preservação Cultural da Universidade de São Paulo, Universidade de São Paulo. v. 6, p. 188-197, 2008.

[76] SUFFREDINI, H. B.; TRICOLI, V.; VATISTAS, N.; AVACA, L. A. Electrooxidation of methanol and ethanol using a $\mathrm{Pt}-\mathrm{RuO}_{2} / \mathrm{C}$ composite prepared by the sol-gel technique and supported on boron-doped diamond. Journal of Power Sources, v. 158, p.124-128, 2006.

[77] OtTONi, C. A., RAMOS, C. E. D., DA Silva, S. G., SPINACE, E. V., DE SOUZA, R. F. B., NETO, A. O. Glycerol and Methanol Electro-oxidation at Pt/C-ITO under Alkaline Condition. Electroanalysis, V. 28, p. 2552-2558, 2016.

[78] LITSTER, S.; MCLEAN, G. PEM Fuel Cell Electrodes. Journal Power Sources, v. 130, p. 61-76, 2004. 
[79] FREY, T.; LINARDI, M. Effects of Membrane Electrode Assembly Preparation on the Polymer Electrolyte Membrane Fuel Cell Performance. Electrochimica Acta, v. 50, p. 99-105, 2004.

[80] KIM, G.; EOM, K.; KIM, M.; YOO, S. J.; JANG, J. H.; KIM, H. J.; CHO, E. Design of an Advanced Membrane Electrode Assembly Employing a Double-Layered Cathode for a PEM Fuel Cell. ACS Applied Materials Interfaces, v. 7, p. 27581-27585, 2015.

[81] CHAN, B. C.; LIU, R.; JAMBUNATHAN, K.; CHEN, H. Z. G.; MALLOUK, T. E.; SMOTKIN E. S. Comparison of High-Throughput Electrochemical Methods for Testing Direct Methanol Fuel Cell Anode Electrocatalysts. Journal of the Electrochemical Society, v. 152, p. A594-A600, 2005.

[82] RIVERA, E. C.; VOLPE, D. J.; ALDEN, L.; LIND, C.; DOWNIE, C.; ALVAREZ, T. V.; ANGELO, A. C. D.; DISALVO, F. J.; ABRUNA, H. D. Electrocatalytic Activity of Ordered Intermetallic Phases for Fuel Cell Applications. Journal of the American Chemical Society, v. 126, p.4043-4049, 2004.

[83] PARK, I-S.; LEE, E.; MANTHIRAM, A. Electrocatalytic Properties of Indium Tin Oxide-Supported Pt Nanoparticles for Methanol Electro-oxidation. Journal of the Electrochemical Society, v. 157, p. B251-B255, 2010. 